Portland State University

PDXScholar

Dissertations and Theses

Dissertations and Theses

9-10-1993

\title{
Water Quality Modeling of the Tualitin River
}

Christopher John Berger

Portland State University

Follow this and additional works at: https://pdxscholar.library.pdx.edu/open_access_etds

Part of the Civil Engineering Commons

Let us know how access to this document benefits you.

Recommended Citation

Berger, Christopher John, "Water Quality Modeling of the Tualitin River" (1993). Dissertations and Theses.

Paper 4742.

https://doi.org/10.15760/etd.6626

This Thesis is brought to you for free and open access. It has been accepted for inclusion in Dissertations and Theses by an authorized administrator of PDXScholar. Please contact us if we can make this document more accessible: pdxscholar@pdx.edu. 
THESIS APPROVAL

An abstract and thesis of Christopher John Berger for the Master of Science in Civil Engineering were presented September 10, 1993 and accepted by the thesis committee and the department.

COMMITTEE APPROVALS:
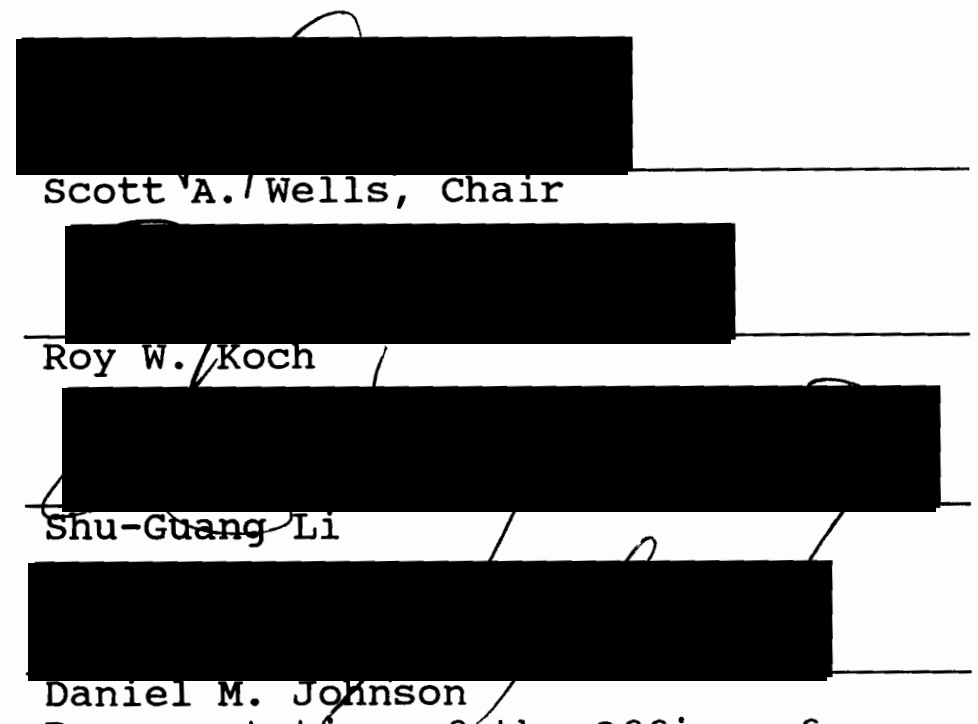

Representative of the office of Graduate studies

DEPARTMENT APPROVAL:
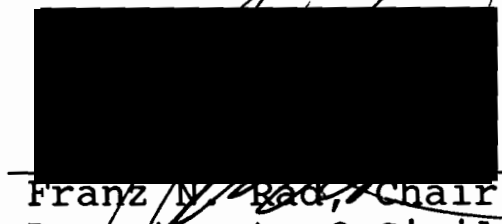

Department of Civil Engineering

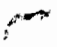

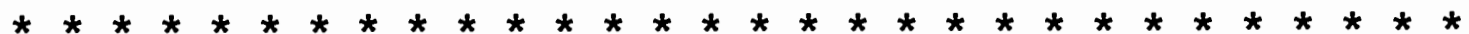

ACCEPTED FOR PORTLAND STATE UNIVERSITY BY THE LIBRARY

by

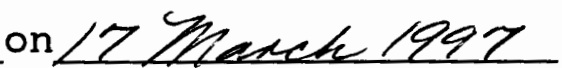




\section{ABSTRACT}

An abstract of the thesis of Christopher John Berger for the Master of Science in Civil Engineering presented September 10,1993 .

Title: Water Quality Modeling of the Tualatin River

Water quality problems related to excessive algal growth, high nutrient loading, and low flows have been occurring along oregon's Tualatin River. The Tualatin River is 86 miles long and has a drainage basin of 711 square miles. The drainage basin incorporates forest, agricultural, and urban areas. Located in the Portland metropolitan area, these problems have been acerbated by the effects of urban growth. To help analyze pollution control alternatives, a river model study, funded by the oregon Department of Environmental Quality (DEQ), was undertaken. An in-stream model of hydraulics and water quality was developed. The Corps of Engineer's CE-QUAL-W2 model, a twodimensional, laterally averaged, dynamic model of hydrodynamics and water quality was applied to the Tualatin system. Calibration of the main pool model of the Tualatin River was from field data taken during June through August of 1991. Verification of the model was performed from field 
data taken during the summer of 1990. After calibration and verification of the model, management alternatives were evaluated in order to achieve DEQ mandated water quality standards. Environmental performance criteria were determined to evaluate differences between model scenarios. Management alternatives focused on the reduction of point and non-point sources of pollution, flow augmentation, and structural changes in the river system, such as removal of the Lake Oswego Diversion Dam. 
WATER QUALITY MODELING OF THE

TUALATIN RIVER

by

CHRISTOPHER JOHN BERGER

$\therefore$

A thesis submitted in partial fulfillment of the requirements for the degree of

MASTER OF SCIENCE

in

CIVIL ENGINEERING

Portland State University

1994 


\section{ACKNOWLEDGEMENTS}

The research in this thesis is part of a project funded by the State of Oregon's Department of Environmental Quality to study the Tualatin River Basin. The project was a collaborative effort between Portland State University and oregon State University.

I would like to thank the D.E.Q. for their financial support which gave me an opportunity to work on a fascinating project while obtaining a first-rate education. Much gratitude is expressed to $\mathrm{Dr}$. Scott Wells for all his guidance, help, and inspiration. I would also like to thank those who worked on the project with me at P.S.U., Dr. Roy Koch, Mike Knutson, Patrick Moore, and Fei Tang. They all contributed to an educational experience which I will always treasure. I would especially like to acknowledge my family, whose encouragement and unwavering support have allowed me to pursue my dreams. 
TABLE OF CONTENTS

PAGE

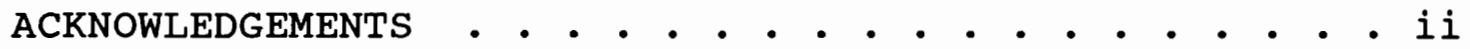

LIST OF TABLES . • . . . . . . . . . . . . . . . . v

LIST OF FIGURES . . . . . . . . . . . . . . . . vi

CHAPTER

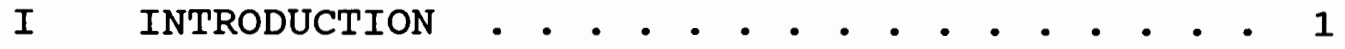

Tualatin River Basin .. . . . . . 1

Water Quality Issues... . . . . 8

II BACKGROUND . . . . . . . . . . . 10

Phosphorus Modeling . . . . . . 10

Empirical Models . . . . . . . 12

Dynamic Models . . . . . . . . 18

III MODEL DESCRIPTION . . . . . . . . . . 28

Introduction . . . . . . . . . 28

Governing Equations . . . . . . 29

Constituents . . . . . . . . . 32

Model Domain . . . . . . . . 33

Numerical Solution . . . . . . . 38

Diversion Dam Algorithm . . . . . 39

IV MODEL CALIBRATION AND VERIFICATION . . . . 45

Introduction . . . . . . . . . 45

Calibration of Hydrodynamics . . . . 46 


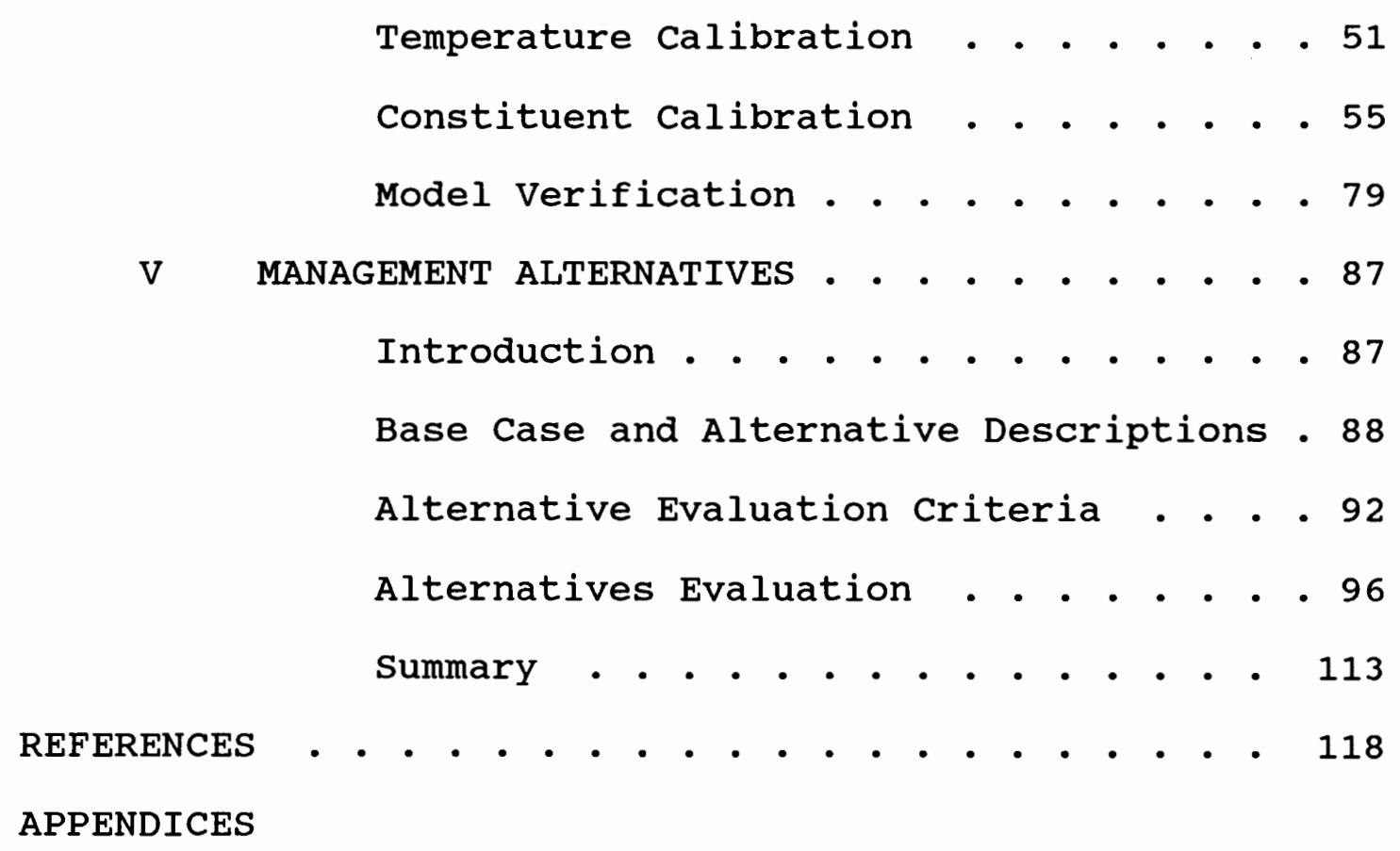

A WATER QUALITY CYCLES IN CE-QUAL-W2 • • • • 124

B USER'S MANUAL FOR MODIFIED VERSION OF CE-QUAL-W2 OF THE TUALATIN RIVER • • • 141 


\section{LIST OF TABLES}

\section{TABLE}

PAGE

I Final Calibration Parameters . • . . 72

II Pollution Control Alternatives . . . . 88

II Mean and Standard Deviations of Constituents at stafford Bridge and Elsner Bridge . . . . . . . 98

IV Management Alternative Rankings . . 100

A-1 Equations Used for Water Quality Cycles in CE-QUAL-W2 . . . . . . . . . 125

A-2 Variable Definitions for Water Quality Cycle Equations Used in CE-QUAL-W2 . . . . . . . . . . 131

B-1 Organization of the Tualatin River Model Computer Files . . . . . 143

B-2 User's Manual • . . . . . . . . 149

B-3 Simulation Files for the Tualatin

River Pool . . . . . . . . . 149 


\section{LIST OF FIGURES}

FIGURE

PAGE

1. Tualatin River Basin . . . . . . . 2

2. Tualatin River Channel Bottom Elevations . . . . . . . . . . . 4

3. Phosphorus Model Developed by o'Melia, Imboden, and Snodgrass . . . . 21

4. Cycling Between Available and Unavailable Phosphorus Pools and Algae . . . 23

5. Schematic of Lorenzon's Sediment-Water Model . . . . . . . . . . 24

6. Orthophoshorus Sources/sinks of the Model ........... . 26

7. Layout of the Longitudinal Segments for the Tualatin River Pool Model . . 34

8. Vertical Cell Layout for each Crosssection for CE-QUAL-W2 Model . . 35

9. Approximate Representation of the Computational Grid for the Tualatin River Pool Model . . . 36

10. Sketch of the Diversion Dam . . . . . 41

11. Flowchart showing Diversion Dam Algorithm . . . . . . . . 42

12. Schematic of Lower Tualatin River . . 47

13. Calibration Results for Flow, Water Surface Elevation, and Temperature . . . . . . . . . 49

14. Model Predicted Water Surface Profiles . 50

15. Calibration Results for Temperature stratification at Elsner Bridge . . 53 
16. Calibration Results for Temperature Stratification at Stafford Bridge . 54

17. Calibration Results for Chlorophyll a and Dissolved oxygen ... . . 62

18. Calibration Results for Orthophosphorus and Biochemical Oxygen Demand . . 63

19. Calibration Results for Ammonia Nitrogen and Nitrite/Nitrate Nitrogen . . 64

20. Calibration Results for Total Suspended Solids and Total Dissolved Solids . 65

21. Calibration Results for $\mathrm{pH}$ and Model Predicted Zooplankton ... . . 66

22. Model Predicted Alkalinity and Inorganic Carbon for the Calibration Run . . 67

23. Calibration Results for Dissolved oxygen Stratification at Elsner Bridge . 68

24. Calibration Results for Dissolved oxygen Stratification at Stafford Bridge • 69

25. Model Predicted Chlorophyll a Stratification for the calibration Run at Elsner Bridge . . . . 70

26. Model Predicted Chlorophyll a Stratification for the calibration Run at Stafford Bridge . . . . 71

27. Verification Results for Flow, Water Surface Elevation, and Temperature ....... . . . 81

28. Verification Results for Chlorophyll a and Dissolved oxygen . . . . . . 82

29. Verification Results for orthophosphorus and Biochemical Oxygen Demand . . 83

30. Verification Results for Ammonia Nitrogen and Nitrite/Nitrate Nitrogen . . 84

31. Verification Results for Total Suspended Solids and Total Dissolved Solids . 85 
32. Verification Results for $\mathrm{pH}$ and Model

Predicted Zooplankton . . . . 86

33. Histograms showing Water Quality

Violations for the Base Case . . 103

34. Histograms showing Water Quality

Violations for the 100 cfs Flow

Augmentation Alternative . . . 104

35. Histograms showing Water Quality

Violations for the 200 cfs Flow

Augmentation Alternative . . . 105

36. Histograms showing Water Quality

Violations for the Flash Boards

Down Alternative . . . . . 106

37. Histograms showing Water Quality

Violations for the $100 \mathrm{cfs}$ Flow

Augmentation and Flash Boards

Down Alternative . . . . . 107

38. Histograms showing Water Quality

Violations for the $50 \%$ Reduction in

Phosphorus Loading Alternative • 108

39. Histograms showing Water Quality

Violations for the No Dam

Alternative . . . . . . . 109

40. Bar Graph Comparing Management

Alternative Chlorophyll-a

violations .......... 110

41. Bar Graph Comparing Management

Alternative Dissolved Oxygen

Violations . . . . . . . .

42. Bar Graph Comparing Management

Alternative $\mathrm{pH}$ Violations . . . 112

A.1. Algae Sources/Sinks . . . . . . 134

A.2. Coliform First Order Decay Process . . 134

A.3. Detritus Sources/Sinks . . . . . 135

A.4. Dissolved oxygen Sources/Sinks . . . 135

A.5. Inorganic Carbon Sources/Sinks . . . 136 
A.6. Inorganic Suspended Solids

Sedimentation . . . . . . 136

A.7. Labile Dissolved Organic Matter

Sources/Sinks . . . . . . . 137

A. 8. Ammonia-N Sources/Sinks . . . . . 137

A.9. Nitrite+Nitrate Sources/Sinks . . . 138

A.10. Orthophosphorus Sources/Sinks . . . 138

A.11. Refractory Dissolved Organic Matter

Sources/Sinks . . . . . . . 139

A.12. Sediment Accumulation/Decay . . . . 139

A.13. Total Iron Sources/Sinks . . . . 140

A.14. Zooplankton Sources/Sinks .... . 140 
CHAPTER I

\section{INTRODUCTION}

\section{TUALATIN RIVER BASIN}

oregon's Tualatin River originates as a fast moving stream, flowing eastward through the forested slopes of the Coast Range into the flat farmlands of washington county, where it becomes a slow, meandering river, coursing through rural and urban settings before emptying into the willamette River (Figure 1). Prior to the arrival of western civilization, the river basin consisted of forests and wetlands. The lowlands surrounding the Tualatin and its tributaries were marshy, allowing filtration and providing ample storage for runoff. After settlement in the 1800's, the character of river changed in response to the basin's population growth and increased demands on the its resources. Marshes were drained to make room for farm land, and forests were harvested for lumber. Water was withdrawn from the river for agricultural and domestic purposes, while wastewater and runoff from agricultural and urban lands was returned (Cass and Miner, 1993). Today, with its lower stretches located in Portland's metropolitan area, the river is highly affected by the large population nearby and the heavy agricultural use that occurs within its drainage. 


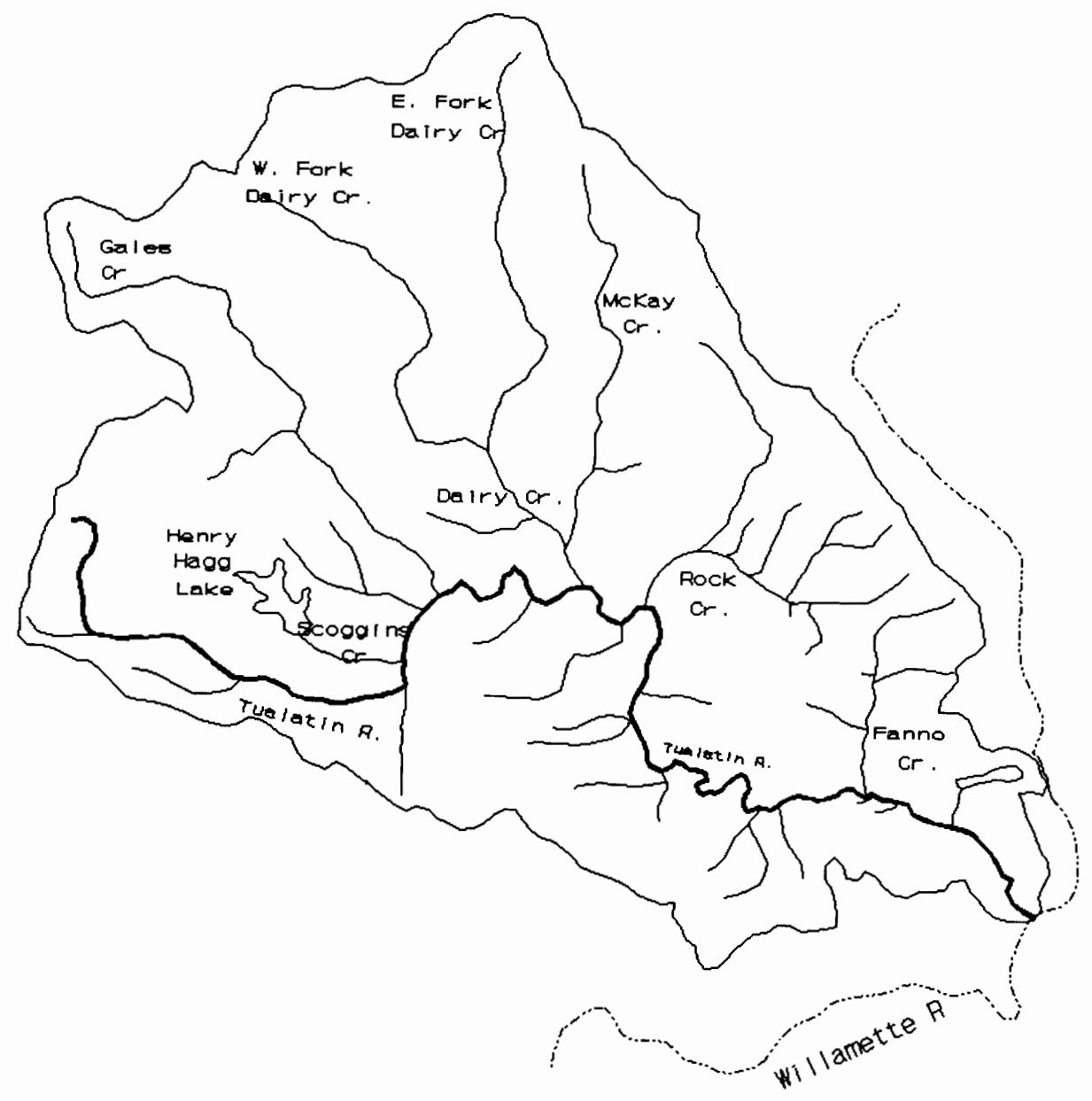

Figure 1. Tualatin River basin (Tang, 1993). 
As is typical for western oregon, precipitation falls within the Tualatin basin primarily from october to March. A seasonal snowpack does not develop in the Coast Range, so river flow follows the annual precipitation cycle and declines significantly in the summer months (Hubbard, et al 1991). This seasonal pattern creates low river flows in the summer when agricultural and domestic water demand is at its peak, and high flows in the winter when demand is at its minimum. River resources are severely stressed through the summer months. Besides having low summer flows, water quality conditions are acerbated by the small slope, or "flatness", of a 30 mile stretch on the lower river (Figure 2). The mild slope is aggravated by Lake Oswego Diversion Dam (also called the Oregon Iron \& Steel Diversion Dam) located at river mile 3.5. Although the dam is only three feet high, a long pool forms behind it. In the summer, when the height of the dam is increased by 2 to 3 feet to augment flow into the Lake Oswego Canal, water surface levels are controlled by the dam for a stretch of river reaching 30 miles upstream. The combination of small slope and a dam creates a sluggish, slow moving lower river. The large water volume behind the dam increases the river's crosssectional area, producing lower flow velocities and greater river detention times. When these effects are united with the high nutrient levels found in the river, the consequence is a eutrophic, lake-like, river system. 
TUALATIN RIVER CHANNEL BOTTOM ELEVATIONS

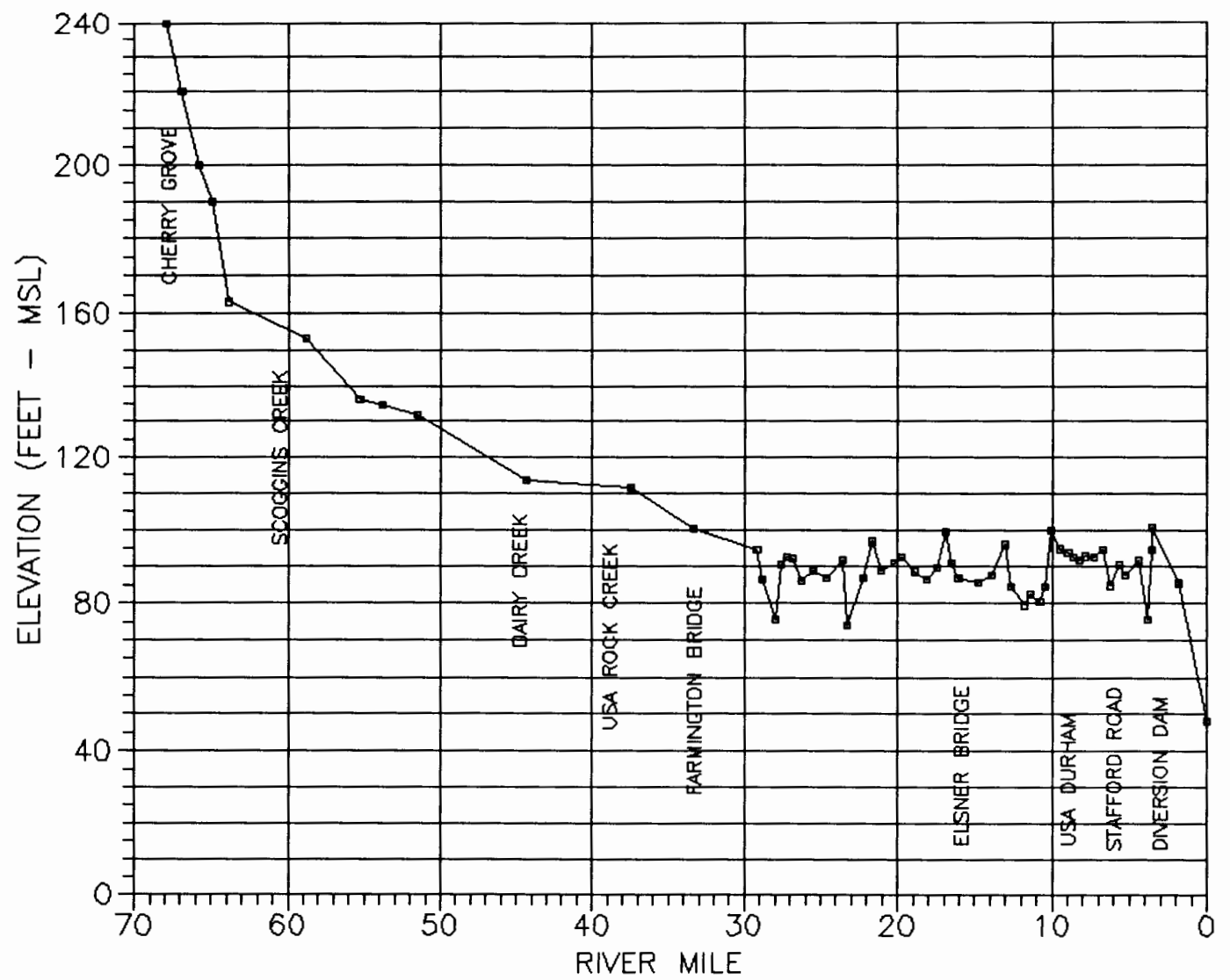

Figure 2. Graph showing Tualatin River channel bottom elevations from Cherry Grove to the Willamette River. Note the lack of fall in the lower river from Farmington Bridge to the Lake Oswego Diversion Dam.

The Tualatin River has many tributaries, water rights, and wastewater treatment discharge facilities which affect its flow. The 86 mile long main stem originates in the Coast Range southwest of Forest Grove. Mostly for water quality reasons, summer flow in the upper Tualatin is augmented by water from Barney Reservoir in the Trask River system, located just across the crest of the coast Range from the headwaters of the Tualatin. From April to November of 1992, an average of 8 cubic feet per second was diverted 
from Barney Reservoir into the Tualatin (Watermaster District 18,1992$)$. Despite the contribution from Barney Reservoir to the main stem Tualatin, most of the river's summer flow comes from Henry Hagg Lake, located on Scoggins Creek and impounded by scoggins Dam. Completed in 1974, Henry Hagg Reservoir is a United States Bureau of Reclamation project constructed as a multipurpose water resource development. Its functions are: to supply water for irrigation; to provide water for municipal and industrial usage; to improve water quality in the Tualatin River with increased flow; to provide recreation; and to provide flood control (Tualatin Valley Irrigation District, 1992). The dam is operated by the Tualatin Valley Irrigation District, which also manages the Bureau of Reclamations Tualatin Valley Irrigation Project. Dam operation reflects the region's large summer demand for water. During the winter, the reservoir, drawn down by the previous summer's usage, is refilled. Unless a large storm event requires otherwise, discharges during the winter are maintained around the minimum allowable flow of $10 \mathrm{cfs}$, and the reservoir is generally full by May 1 . With the arrival of the summer dry season, flow in the Tualatin main stem and tributaries decreases dramatically. The lack of rain creates a large water demand for municipal, agricultural, and water quality purposes. This demand is usually satiated by increased releases from the reservoir, as various 
governmental organizations call in and order their stored allotments of water. From July to september, the typical release rate is in the range between 150 to 200 cfs (Watermaster District 18, 1992). Given that the Tualatin's outflow into the willamette during this time is generally between 100 to $300 \mathrm{cfs}$, the reservoir's contribution is of critical importance to the basin's summer water supply.

Scoggins Creek flows into the Tualatin at river mile 60. Other than Scoggins Creek, there are only a handful of natural tributaries which contribute significant flow to the Tualatin during the summer. The largest of these is Dairy creek, draining primarily agricultural and forested lands which cover nearly a third of the basin's total area. The other major tributaries are Gales creek, which also drains agricultural and forested lands; Rock Creek, draining agricultural, forested, and urbanized areas; and Fanno Creek, draining the urbanized areas of east washington county.

With the exception of Scoggins creek, the largest summer flow contributions are artificial. These are the Unified Sewerage Agency's wastewater treatment plants at Rock Creek (RM 38) and Durham (RM 9.5). Typical summer outflows for both facilities average approximately 20 cfs. Other wastewater treatment plants are located at Forest Grove and Hillsboro. Those facilities are not permitted to discharge into the Tualatin during the summer, and their 
treated wastewater must be recycled or stored until river flows increase in late autumn.

Summer flows on the Tualatin are heavily impacted by water withdrawals. Along the main stem, water right appropriations total $359 \mathrm{cfs}$, although many are not fully utilized or have been abandoned. The largest belongs to Lake Oswego corporation, which can divert a maximum flow of 61 cfs into their canal, at a location several miles upstream (RM 6.7) from the Lake Oswego Canal Diversion Dam. The purpose of the dam is to increase the river's water surface elevation to a height that allows the full water right to flow by gravity into the canal. There is a sluice gate on the canal adjacent to its junction with the Tualatin River which is used to maintain flow into the canal at the permitted rate. Other large state water rights belong to the municipalities of Beaverton, Forest Grove, and Hillsboro, who withdraw their water at the spring Hill Pumping Plant (RM 56.3).

The management of stored water released from Hagg Lake into scoggins creek for irrigation purposes is performed by the Tualatin Valley Irrigation District (TVID). Most of the released irrigation water is diverted from the river by down stream pumping stations and distributed to users through a pressurized pipe network. The Irrigation District operates and maintains the pumping plants and distribution system. The largest pumping facility is the spring Hill 
Pumping Plant which has a capacity for irrigation use of 141 cfs. The pumping plant also has additional pumping capacity for delivering water for municipal use to the Joint Utilities Commission, which supplies water for nearby communities.

\section{WATER QUALITY ISSUES}

The most severe water quality problems on the river exist within the long pool behind the Lake oswego Diversion Dam. In the summer of 1991, algae populations, dissolved oxygen concentrations, and $\mathrm{pH}$ violated DEQ water quality standards. Violations of $\mathrm{pH}$ and dissolved oxygen standards were directly related to algae population dynamics. In periods of abundant short wave solar radiation and nutrients, rising algal growth resulted in an increase of $\mathrm{pH}$ and dissolved oxygen. Algae population trends are followed by measuring the concentration of chlorophyll-a, which is a pigment used by algae for photosynthesis. During the blooms chlorophyll-a concentrations and $\mathrm{pH}$ exceeded the DEQ standards of $15 \mu \mathrm{g} / 1$ and $8.5 \mu \mathrm{g} / 1$, respectively. When sunshine diminished or critical nutrients ran out, the bloom was followed by a population decline, and decomposition of the dead algal mass resulted in a rapid drop in dissolved oxygen concentrations, sometimes dipping below the minimum standard of $6.0 \mathrm{mg} / 1$.

In response to the water quality violations, the DEQ 
established Total Maximum Daily Loads (TMDL) to control point sources of phosphorous and ammonia. The phosphorus TMDL was created to control algal growth whereas the ammonia TMDL was established to alleviate ammonia toxicity and dissolved oxygen depletion due to ammonia oxidation. This study was also initiated to formulate and evaluate pollution control alternatives. To help evaluate the alternatives, a hydrologic model of the Tualatin River watershed was developed along with an in-stream model which included the main stem Tualatin, Scoggins Creek, and Henry Hagg Reservoir. The topic of this thesis is the development of the in-stream model segment which simulates the Tualatin River from the Lake Oswego Diversion Dam to the approximate end of the reservoir which forms behind it. 
CHAPTER II

BACKGROUND

\section{PHOSPHORUS MODELING}

Algal blooms are caused by excessive nutrients stimulating algal growth. In most freshwater systems, phosphorus limits algal growth because it is the least abundant nutrient (Thomann and Mueller, 1987). When the amount of phosphorus loading into a lake or river increases over time, eutrophication is accelerated. Because algal growth can be limited by the availability of phosphorus, there has been an extensive effort to create models which can predict and simulate the effects phosphorus concentration has on water quality. These models have been empirical or theoretical, based on steady-state phosphorus balances derived from a statistical evaluation of a large number of lakes or based on the dynamics of nutrient concentrations and algal populations. The models can predict algal concentrations, chlorophyl1-a concentrations, or the productivity, also referred to as the "trophic state" of a water body. The trophic state refers to a method of classifying water bodies according to their production of aquatic plants and was developed to help identify systems experiencing water quality problems. A water body can be 
categorized as eutrophic, mesotrophic, or oligotrophic. Eutrophic lakes and rivers are highly productive and characterized by abundant algal growth and high turbidity, typically undergoing wide swings in dissolved oxygen and $\mathrm{pH}$. oligotrophic water bodies, on the other hand, are clear and experience low production of aquatic plants. Mesotrophic lakes are intermediate productivity lakes.

Most of the empirical models predict steady-state phosphorus or chlorophyll-a concentration. Trophic state is then inferred from the predicted concentration. Model inputs are those thought to affect the lake productivity, such as phosphorus loading and detention time (Ahlgren, Frisk, and Kamp-Nielsen, 1988).

Dynamic phosphorus models are theoretically more accurate than empirical models, but they require much more data, time and money to implement. They are particularly useful when simulating the time-dependent effects of phosphorus impulse loadings. Their complexity ranges from simple mass balance models using continuously stirred tank reactors to those employing partial differential equations governing mass transport.

Due to their simplicity, empirical models can give a manager an estimate of the long-term effect a phosphorus load will have on the trophic status of a water body at low cost. If more specific information is necessary and the funds are available, a dynamic model can provide a more 
detailed prediction of phosphorus and algal concentrations along with their seasonal variations.

EMPIRICAL MODELS

Models which Predict Trophic state using P Concentration

The link between phosphorus abundance and trophic state led to the creation of models which use phosphorus as the indicator variable. Assumptions made in the development of these models include: the limiting nutrient is phosphorus; steady-state conditions exist; the water body could be modeled as a continuously stirred reactor; and phosphorus concentration is a reliable indicator of trophic state (Thomann and Mueller, 1987). In order to infer the trophic state using the phosphorus concentration, a phosphorus mass balance is used to estimate the phosphorus concentration. Assuming a completely stirred water body, the mass balance can be expressed as

$$
V \frac{d p}{d t}=w-Q p-S
$$

where

$$
\begin{aligned}
& \mathrm{p} \text { - phosphorus concentration }\left[\mathrm{ML}^{-3}\right] ; \\
& \mathrm{V} \text { - volume of water body }\left[\mathrm{L}^{3}\right] ; \\
& \mathrm{W} \text { - phosphorus load }[\mathrm{M} / \mathrm{T}] ; \\
& \mathrm{Q} \text { - outflow rate }\left[\mathrm{L}^{3} / \mathrm{T}\right] \\
& \mathrm{S} \text { - source/sink term }[\mathrm{M} / \mathrm{T}] .
\end{aligned}
$$

For the empirical phosphorus models, the source/sink term is generally used to simulate losses due to sedimentation and is always a sink. However, one of the initial attempts at 
phosphorus modeling presumed sedimentation was a function of loading (Piontelli \& Tonolli, 1964):

$$
V \frac{d p}{d t}=\left(1-f_{s}\right) W-Q p
$$

where $f_{s}$ represents the fraction of phosphorus loading lost to sediment. A conceptual improvement was made when Vollenweider (1968) suggested that the mass loss due to sedimentation was proportional to the phosphorus concentration in the system. This assumption was more plausible since sedimentation is a function of the system's phosphorus concentration within the water body rather than the concentration of an the inflow. This idea was formulated in a sink term representing sedimentation, such that the phosphorus mass balance became

$$
V \frac{d p}{d t}=W-v_{s} A_{s} p-Q p
$$

where $v_{s}$ is the net settling rate $[L / T]$ and $A_{s}$ is surface area of the water body $\left[\mathrm{L}^{2}\right]$. To further simplify the model, steady-state conditions were assumed. Hence, dynamic behavior of the system is ignored. The steady-state solution is

$$
p=\frac{W}{Q+V_{S} A_{S}}
$$


which can also be written as

$$
p=\frac{L}{z\left(\frac{1}{\tau}+\sigma\right)}
$$

where

$$
\begin{aligned}
& L=\frac{W}{A_{S}} \\
& \sigma=\frac{V_{s}}{Z} \\
& \tau=\frac{V}{Q}
\end{aligned}
$$

z - mean depth.

$\tau, L$, and $\sigma$ correspond to the hydraulic detention time [T], the areal loading rate $\left[\mathrm{MT}^{-1} \mathrm{~L}^{-2}\right]$, and the sedimentation coefficient $\left[\mathrm{T}^{-1}\right]$. Except for the sedimentation coefficient, the variable inputs for (5) can be easily obtained or estimated. The formulation of the solution represented by (5) is based on the assumption that the sedimentation is dependent upon lake depth and phosphorus concentration. Other investigators (Chapra, 1975; Dillon and Kirchner, 1975) concluded that settling velocity was 
constant and the mass balance solution as expressed by (4) better illustrates the mechanism of sedimentation, implying that it is a function of lake surface area rather than depth. Vollenweider suggested a sedimentation coefficient defined by

$$
\sigma=\frac{10}{z}
$$

where

$$
\text { z - average depth in meters. }
$$

Equation (9) implies that $\mathrm{v}_{\mathrm{s}}=10 \mathrm{~m} / \mathrm{yr}$.

Models which estimate steady-state phosphorus concentrations are often based on three assumptions: sedimentation is a function of depth and phosphorus concentration; sedimentation is an areal sink; and sedimentation is a function of phosphorus loading. Vollenweider's model is typical of those in the first category. Models based on the assumption that sediments are a function of surface area include those proposed by Chapra (1975)

$$
p=\frac{L}{16+\frac{z}{\tau}}
$$

and Dillon and Kirchner (1975) 


$$
p=\frac{L}{13.2+\frac{z}{\tau}}
$$

Models which assume that sedimentation is a function of phosphorus include the one described by Dillon, Rigler, and Kirchner (1975):

$$
p=\frac{L \tau}{z}\left(1-f_{s}\right)
$$

where

$$
f_{s}=0.426 \exp \left(-0.271 \frac{z}{\tau}\right)+0.574 \exp \left(-0.0095 \frac{z}{\tau}\right)
$$

Using the estimate of the steady-state phosphorus concentration, the trophic status of the water body can be predicted by comparing the concentration to benchmark values corresponding to thresholds for eutrophic or oligotrophic lakes. Vollenweider (1975) suggested the following benchmarks: if the estimated concentration is less than 0.01 $\mathrm{mg} / \mathrm{l}$, the phosphorus level is considered acceptable and the lake is classified as oligotrophic; if the estimate is greater than $0.02 \mathrm{mg} / 1$, the phosphorus concentration is considered excessive and the lake is classified eutrophic.

\section{Chlorophyl 1-a Models}

Another approach to determining the trophic status of a water body is to estimate the chlorophyll-a concentration 
given the phosphorus concentration. Dillon and Rigler (1974) used a sample of 19 lakes located in Southern Canada to develop a regression line that could be used to predict average summer chlorophyll-a concentration from a single measurement of spring phosphorus concentration:

$$
\log _{10}(c h 1)=1.449 \log _{10}(p)-1.136
$$

where

$$
\begin{aligned}
& \mathrm{chl} \text { - chlorophyll-a concentration in } \mathrm{mg} / \mathrm{l} \text {; } \\
& \mathrm{p} \text { - total phosphorus concentration in } \mathrm{mg} / \mathrm{l} \text {. }
\end{aligned}
$$

Chapra and Tarachak (1976), building upon the models estimating phosphorus concentration, developed a regression equation that predicts summer chlorophyl1-a concentration given the phosphorus loading. Using Dillon and Rigler's regression relating chlorophyll-a and phosphorus and applying it to the steady-state mass balance solution of

$$
p=\frac{L}{\frac{Q}{A_{S}}+V_{S}}
$$

they developed the equation

$$
\operatorname{ChI}=1866\left(\frac{L}{q+12.4}\right)^{1.449}
$$

where 


$$
q=\frac{Q}{A_{S}}
$$

chl - chlorophyll-a concentration in $\mu \mathrm{g} / 1$;

$\mathrm{L}$ - phosphorus loading in $\mathrm{gm}^{-2} \mathrm{yr}^{-1}$;

$q$ - inflow rate per unit area $(\mathrm{m} / \mathrm{yr})$.

With this expression the mean summer chlorophyll-a concentration can be estimated for a typical water body for which the inflow and phosphorus loading is known. This relation used a net settling velocity of $12.4 \mathrm{~m} / \mathrm{yr}$, in contrast to the $10.0 \mathrm{~m} / \mathrm{yr}$ suggested by Vollenweider. Chapra and Tarachak also proposed that a chlorophyl1-a concentration greater than $9.0 \mu \mathrm{g} / 1$ indicates a eutrophic environment.

\section{DYNAMIC MODELS}

Because of the need to improve the predictive abilities of water quality models, theoretical water quality models have been developed which can simulate mass transport and constituent kinetics. These models are generally much more complicated than the steady-state empirical models, but they can provide better insight into the workings of an ecosystem. The belief that the physical, chemical, and biological processes occurring in a water body can be modeled are based on the following premises: (i) the interactions and events can be represented mathematically; (ii) all these processes can be linked into a system which 
adequately simulates the real world (Scavia, 1979). Constituents other than phosphorus can affect a system's phosphorus cycling and are also modeled. These constituents include phosphorus sources and sinks such as detritus and sediment as well as living populations of algae, zooplankton, and fish. The development and proper application of water quality models is dependent upon a good understanding of the interactions occurring within an ecosystem along with the rates at which they occur. The dependence of the theoretical based models upon using the more costly and time consuming approach of establishing growth and reaction rates pays off with the development of theoretically more accurate models. Through the use of quantified rates the theoretical models are much more effective in simulating short-term events such as algal blooms and die-offs. This leads to the usefulness of the dynamic models in the simulation of ecosystem perturbations. Steady-state empirical models are restricted to predicting long-term effects using annual averages.

The complexity of dynamic water quality models varies widely. Mass transport can be simulated with a simple series of continuously stirred reactors or through the use of partial differential equations that require complicated numerical techniques to solve. The recycling of a critical nutrient through its different forms necessitates that all the living organisms and other relevant elements which can 
affect the nutrient are also simulated. A perfect model that can predict all the potential nutrient interactions and transformations is impossible. Phosphorus, for instance, can exist in a variety of chemical and biological forms but the lack of complete understanding about growth and reaction rates requires that the models be simplified to the point where phosphorus states are grouped into a few general categories. Possible phosphorus classifications include organic and inorganic, particulate or dissolved, and living or nonliving.

Chapra and Reckhow (1983) suggested that the kinetic segmentation and the degree of complexity with which phosphorus is modeled should be based on measurement techniques, mechanistic considerations, and the project's management objectives. Some of the early efforts in dynamic phosphorus modeling involved its transformation between different forms and its movement in a vertically stratified lake. In models suggested by O'Melia (1972), Imboden (1974) and Snodgrass (1974), phosphorus is separated into two forms: soluble reactive phosphorus (SRP) and not soluble reactive phosphorus (NSRP). SRP represents orthophosphorus. Transport occurs between two continuously stirred batch reactors corresponding to the epilimnion and the hypolimnion (Figure 3). The rationale for dividing phosphorus into these categories was the availability of field data consisting of SRP and total phosphorus (TP) measurements. 


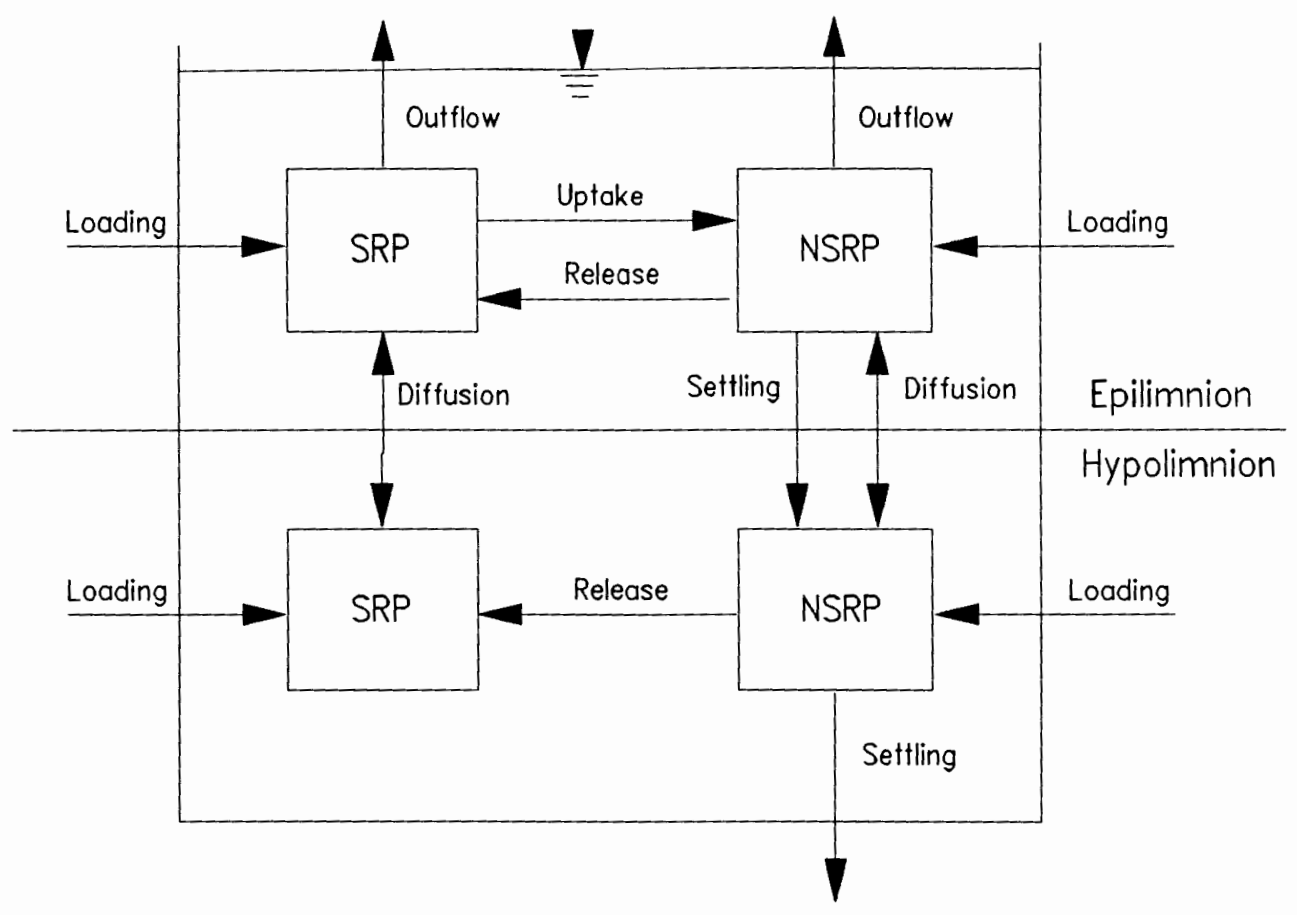

Figure 3. Schematic representation of phosphorus model developed by o'Melia, Imboden, and Snodgrass. (Chapra and Rechkhow, 1983, p. 164)

NSRP concentration was determined by subtracting soluble reactive phosphorus from total phosphorus (NSRP=TP-SRP). An underlying assumption of the model is that most of the NSRP is in particulate form consisting of algae and detritus. Algal growth and phosphorus uptake is represented by the transformation of SRP to NSRP while algal respiration and decomposition is simulated by the phosphorus release from NSRP back to SRP. Movement between the epilimnion and hypolimnion occurs through diffusion of both phosphorus forms and the settling of NSRP. 
other researchers included a separate algal compartment which functioned as a phosphorus source/sink. The non-algal phosphorus was classified according to its suitability for algae uptake (Thomann and Segna, 1980). Phosphorus which can be utilized for algae growth was considered to be approximately equal to the amount of soluble reactive phosphorus (SRP). The unavailable pool consisted of detritus and soluble organic phosphorus forms which cannot be consumed by algae until their conversion into SRP. A further refinement can be made by dividing the unavailable phosphorus into particulate and soluble components (Figure 4). This distinction permits the use of different kinetic rates for the transformation of unavailable phosphorus into SRP. Studies have shown this may occur rapidly for some forms of soluble phosphorus (Herbes 1974, Cowen and Lee 1976). A settling rate for particulate phosphorus forms can also be provided.

The transformation and movement of phosphorus occurs not only in the water column but also between the water body and the sediments. A model was developed by Lorenzon (1974) and Lorenzon et. al (1976) which simulated the accumulation, sorption, and release of total phosphorus by sediments (Figure 5). This model divided sediment phosphorus into exchangeable and non-exchangeable components. The nonexchangeable phosphorus was assumed to be permanently stored within the sediments whereas the exchangeable form 


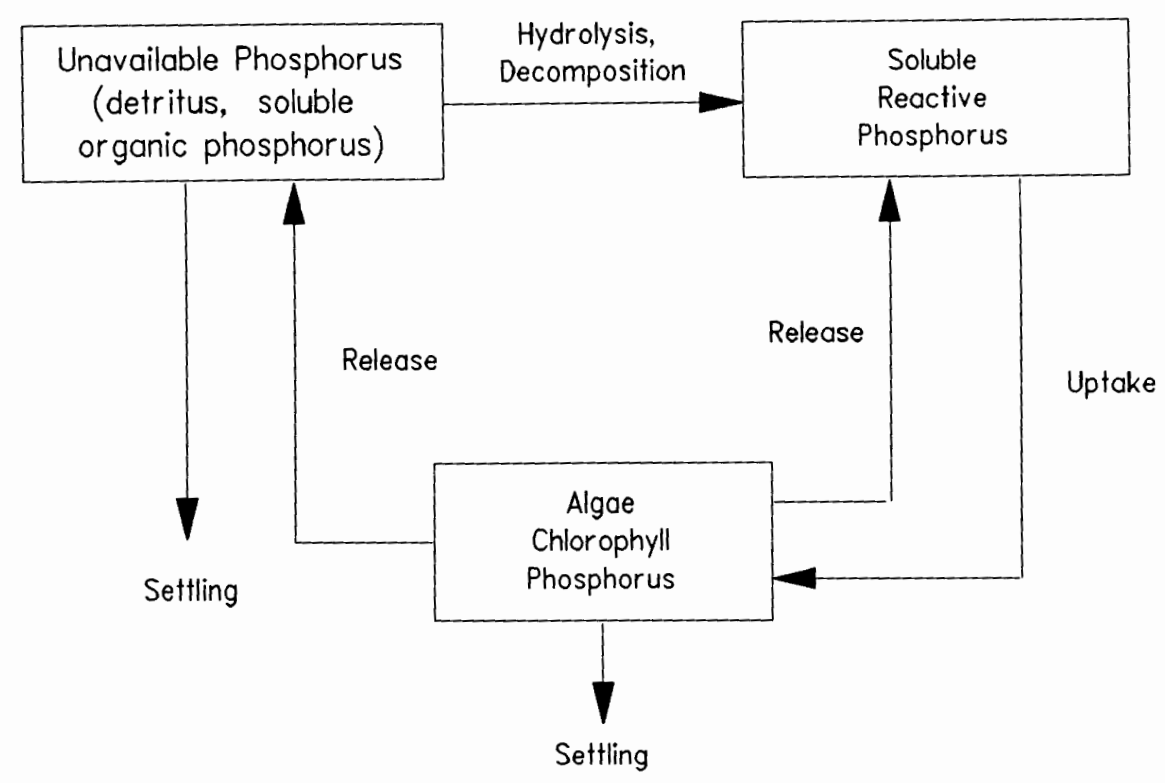

Figure 4. Cycling between available and unavailable phosphorus pools and algae. (Thoman and Mueller, 1987)

could be released back into the water column. Lung et. al. (1976) and Kamp-Nielson (1977) expanded on this model by dividing the total phosphorus into particulate and dissolved forms.

The transformation and interaction of phosphorus components is typically modeled using first-order kinetics. Algal uptake of available phosphorus, or orthophosphate, can be expressed by

$$
\frac{d a}{d t}=k(p) a
$$




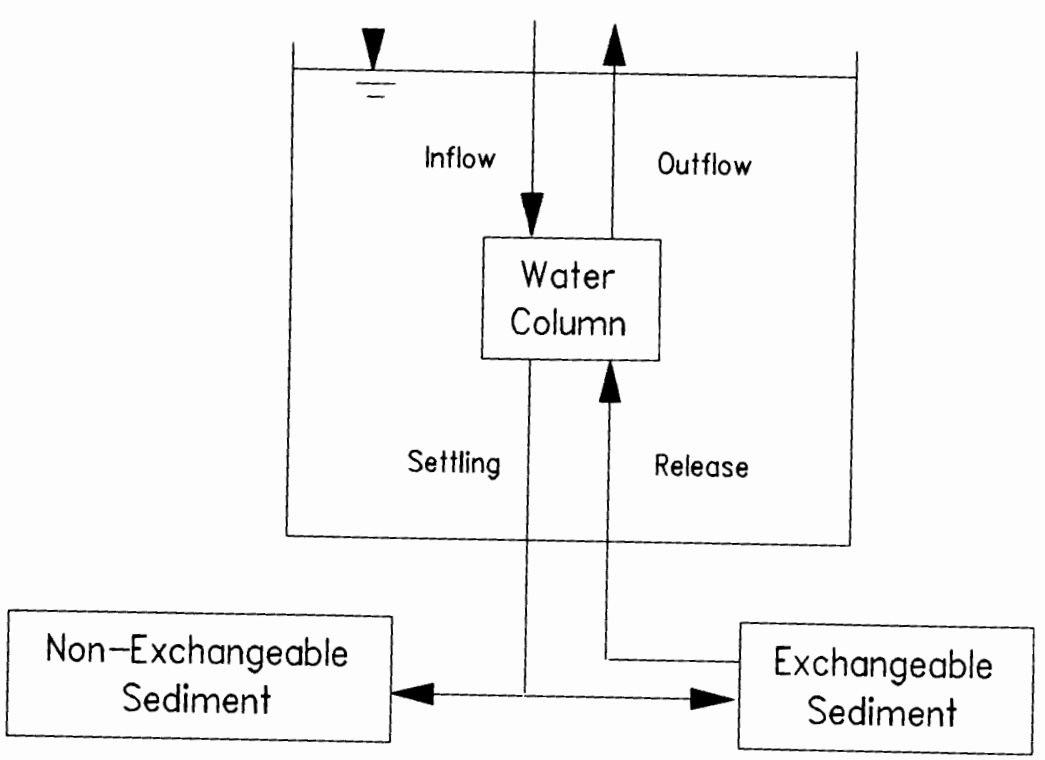

Figure 5. Schematic of Lorenzen's sediment-water model. (Chapra and Reckhow, 1983)

and

$$
\frac{d p}{d t}=-\frac{1}{s} k(p) a
$$

where

$$
\begin{aligned}
& \text { a - concentration of algae }\left[\mathrm{M} / \mathrm{L}^{3}\right] \\
& t \text { - time [T] } \\
& k(\mathrm{p}) \text { - first order reaction rate as a function of } \\
& \text { phosphorus concentration }\left[\mathrm{T}^{-1}\right] \text {. } \\
& s \text { - stoichiometric constant representing the mass of } \\
& \text { organism created per mass of food eaten [M/M]. }
\end{aligned}
$$

The reaction rate $\mathrm{k}(\mathrm{p})$ is dependent upon phosphorus concentration is expressed quantitatively by the Michaelis- 
Menten kinetic relationship of the form

$$
k(p)=\frac{k_{m} p}{k_{s}+p}
$$

where

$\mathrm{k}_{\mathrm{m}}$ - maximum growth rate $\left[\mathrm{T}^{-1}\right]$

$\mathrm{k}_{\mathrm{s}}$ - the concentration at which growth rate is half the maximum rate $\left[\mathrm{M} / \mathrm{L}^{-3}\right]$.

The Michaelis-Menten kinetic relationship can also be used to describe algal uptake of other nutrients. When there is more than one nutrient being modeled, it is necessary to formulate the reaction rate so it is a function of the limitation terms for the individual nutrients. Some relationships used for this purpose include:

$$
R=k\left(n_{1}\right) \times k\left(n_{2}\right) \times k\left(n_{3}\right) \times k\left(n_{4}\right) \ldots k\left(n_{i}\right)
$$

proposed by Chen (1970), Di Toro et al. (1971), and Thomann et al. (1975);

$$
R=\operatorname{Min}\left(k\left(n_{1}\right), k\left(n_{2}\right), \ldots, k\left(n_{i}\right)\right)
$$

by Larsen et al. (1973), Scavia (1980), and Bierman (1976);

$$
R=\frac{n}{\sum_{i=1}^{n}\left(\frac{1}{k\left(n_{i}\right)}\right)}
$$


by Bloomfield et al. (1973) and Park et al. (1974);

$$
R=\frac{1}{n} \sum_{i=1}^{n} k\left(n_{i}\right)
$$

by patten et al. (1975). R represents the net kinetic growth rate $\left[\mathrm{T}^{-1}\right], \mathrm{n}_{\mathrm{i}}$ is the concentration of a nutrient, and $k\left(n_{i}\right)$ is the kinetic growth rate of a nutrient.

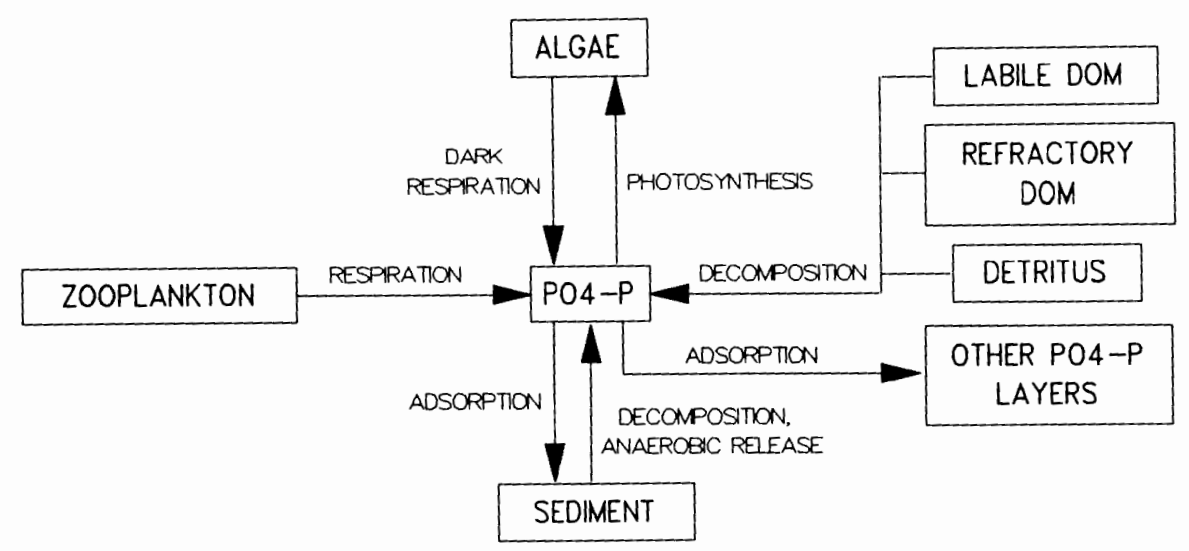

Figure 6. Orthophosphorus sources/sinks of the model.

The model developed for this study uses a variation of (22), with the net kinetic growth rate equal to the minimum fractional growth rates of phosphorus, nitrogen, or light. of course, the fractional growth rate for light does not use the Michaelis-Menten formulation. The model's 
orthophosphorus sources and sinks are illustrated in Figure 6. Sources include decomposition of organic matter and zooplankton and algal respiration. Orthophosphorus sinks include algal photosynthesis and the adsorption of phosphorus by suspended solids which settle out of the water column. 
CHAPTER III

MODEL DESCRIPTION

INTRODUCTION

The Corps of Engineer's environmental simulation model CE-QUAL-W2 was used to evaluate management alternatives. This model is a two-dimensional, laterally averaged, dynamic model of hydrodynamics and water quality. It uses finite difference methods to approximate the six governing partial differential equations and is written in FORTRAN. The model can predict water surface elevations, velocities, temperatures and 22 water quality constituents.

CE-QUAL-W2 was ideally suited for simulating the lower Tualatin. The lower river is analogous to a long, narrow reservoir that has significant water quality and temperature gradients vertically and longitudinally. The model is well matched to the river's topography because its twodimensional domain corresponds to the river's vertical and longitudinal dimensions of the river. For narrow water bodies like the Tualatin River, the lateral, or width-wise direction is relatively insignificant. The governing equations are laterally averaged, the assumption being that lateral variations in hydrodynamic and water quality parameters are negligible. 
The two-dimensional CE-QUAL-W2 has an advantage over one-dimensional models because it is able to simulate the downstream movement of algae and suspended solids in conjunction with movement resulting from settling or vertical velocities. The model is also versatile enough that algorithms can be added which simulate the hydrodynamic and water quality effects of the diversion dam.

\section{GOVERNING EQUATIONS}

CE-QUAL-W2 uses a system of six equations with six unknowns to model fluid motion and mass transport. The 2dimensional laterally averaged equations are derived from the corresponding 3-dimensional equations (Edinger and Buchank, 1978). The Corps of Engineer's CE-QUAL-W2 user's manual (1990) was the source of most of the following information.

The model's governing equation for the conservation of horizontal momentum is

$$
\frac{\partial U B}{\partial t}+\frac{\partial U U B}{\partial x}+\frac{\partial W U B}{\partial z}=-\frac{1}{\rho} \frac{\partial B P}{\partial x}+\frac{\partial}{\partial x}\left(B A_{x} \frac{\partial U}{\partial x}\right)+\frac{\partial B \tau_{x}}{\partial z}
$$

where

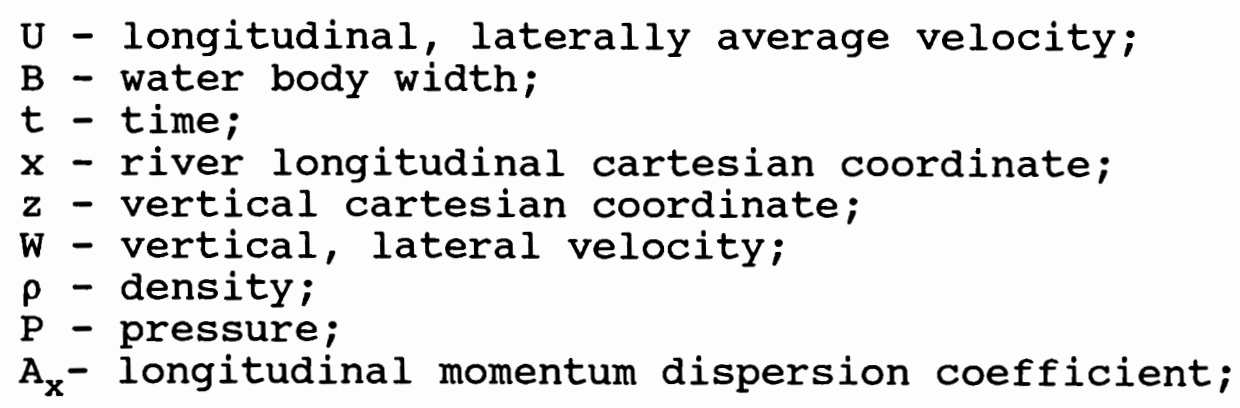


$\tau_{x}$ - shear stress per unit mass resulting from the gradient of the horizontal velocity.

The terms represent, from left to right: the time rate of change of horizontal momentum; the horizontal advection of momentum; the vertical advection of momentum; the force resulting from the gradient in horizontal pressure the dispersion of horizontal momentum; and the force imposed by shear stresses. Vertical accelerations were assumed negligible.

Constituent transport is governed by the laterally averaged advection-diffusion equation

$$
\frac{\partial B \Phi}{\partial t}+\frac{\partial U B \Phi}{\partial x}+\frac{\partial W B \Phi}{\partial z}-\frac{\partial}{\partial x}\left(B D_{x} \frac{\partial \Phi}{\partial x}\right)-\frac{\partial}{\partial z}\left(B D_{z} \frac{\partial \Phi}{\partial z}\right)=q_{\Phi}+S_{K} B
$$

where

$\Phi$ - laterally averaged constituent concentration; $D_{y}$ - dispersion coefficient; $D_{y}$ - vertical temperature and constituent dispersion

$q_{\Phi}$ - lateral infi

$\mathrm{s}_{\mathrm{K}}$ - constituent per unit volume; concentration.

The terms of the advection-diffusion equation represent, moving from left to right: the time rate of change of the constituent; horizontal advection; vertical advection; horizontal dispersion; vertical dispersion; the inflow or outflow source/sink term; and the constituent kinetics 
The free water surface elevation is solved using

$$
\frac{\partial B_{\zeta} \zeta}{\partial t}=\frac{\partial}{\partial x} \int_{\zeta}^{h} U B d z-\int_{\zeta}^{h} q B d z
$$

where

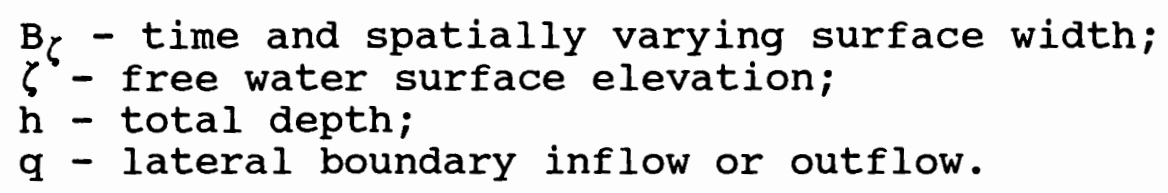

The first term represents the time rate of change of the surface elevation, the next term is the water volume change caused by horizontal advection, and the last term represents volume change caused by tributaries or withdrawals.

The other governing equations utilized by CE-QUAL-W2 are the equation describing hydrostatic pressure,

$$
\frac{\partial P}{\partial z}=\rho g
$$

where

$$
\text { g - acceleration due to gravity; }
$$

the continuity equation,

$$
\frac{\partial U B}{\partial x}+\frac{\partial W B}{\partial z}=q B
$$

where

$$
\text { q - lateral inflow or outflow; }
$$

and the equation of state,

$$
\rho=f(\Phi)
$$

where $f(\Phi)$ is a function which calculates the water density given the temperature, total dissolved solids, and the 
suspended solids.

The system of six governing equations is used to solve the following six unknowns: free water surface elevation, $\zeta$; pressure, $\mathrm{P}$; horizontal velocity, $\mathrm{U}$; vertical velocity, $\mathrm{V}$; constituent concentration, $\Phi$; and density, $\rho$.

\section{CONSTITUENTS}

CE-QUAL-W2 can model the kinetics, transport, and interactions of up to 22 water quality constituents. For the lower Tualatin River, the constituents modeled included: inorganic suspended solids, total dissolved solids, refractory and labile dissolved organic matter, algae, detritus, phosphorus (orthophosphorus, $\mathrm{PO}_{4}-\mathrm{P}$ ), ammonianitrogen $\left(\mathrm{NH}_{3}-\mathrm{N}\right)$, nitrate-nitrogen $\left(\mathrm{NO}_{3}-\mathrm{N}\right)$, dissolved oxygen, inorganic carbon, alkalinity, $\mathrm{pH}$, carbon dioxide, bicarbonate, carbonate, and zooplankton. The mass transport and kinetic source/sink rates for each constituent are governed by the advection-diffusion equation. of course, the nature of the source/sink term is dependent upon the constituent. Each constituent's source/sink term is Iisted in Appendix A, along with figures illustrating its sources and sinks. 
MODEL DOMAIN

\section{Discretization}

The Tualatin River pool model, stretching from river mile 32 to river mile 3.5, is divided into 104 longitudinal segments, each consisting of 19 vertical layers. Thus the model is discretized into a 104 by 19 rectangular grid. However, due to the vertical variations in the river bottom and changing water surface levels, not all of the cells are active. The vertical layers span a domain reaching from 72 feet to 120 feet (mean sea level datum), allowing the model to simulate a large flood and include the river's deepest hole. Each cell is 449 meters (1475 feet) long and has a vertical thickness ranging from 2 feet to 10 feet. All layers below 100 feet MSL, an elevation just a few feet below the average summer water surface elevation, have a thickness of 2 feet, ensuring fairly good vertical resolution except in large floods. The cell layout for the longitudinal segments are shown in Figure 7. Figure 8 shows the vertical cell layout at each cross-section for a CEQUAL-W2 model, while Figure 9 shows the computational grid and the active cells in the Tualatin River pool model. 


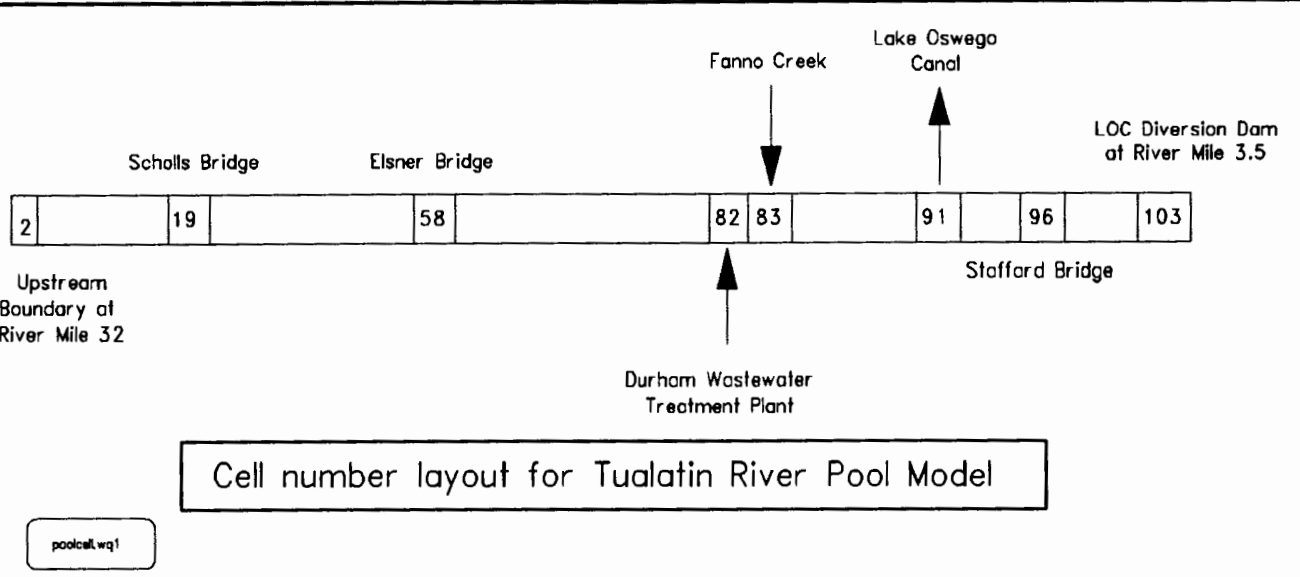

Figure 7. Layout of the longitudinal segments for the Tualatin River pool model.

\section{Bathymetry}

The Tualatin River channel bathymetry data, or channel widths, were developed using cross-sectional surveys. Data sources included USGS and USA channel cross-sections and Oregon Department of Water Resources streamflow records. USGS topographic maps were used to develop portions of the cross-sections in the flood plain. The river cross-sections had to be converted from their initial format into one compatible with the CE-QUAL-W2. This generally involved establishing the elevation of each cross-section in reference to mean sea level, transforming the elevations 


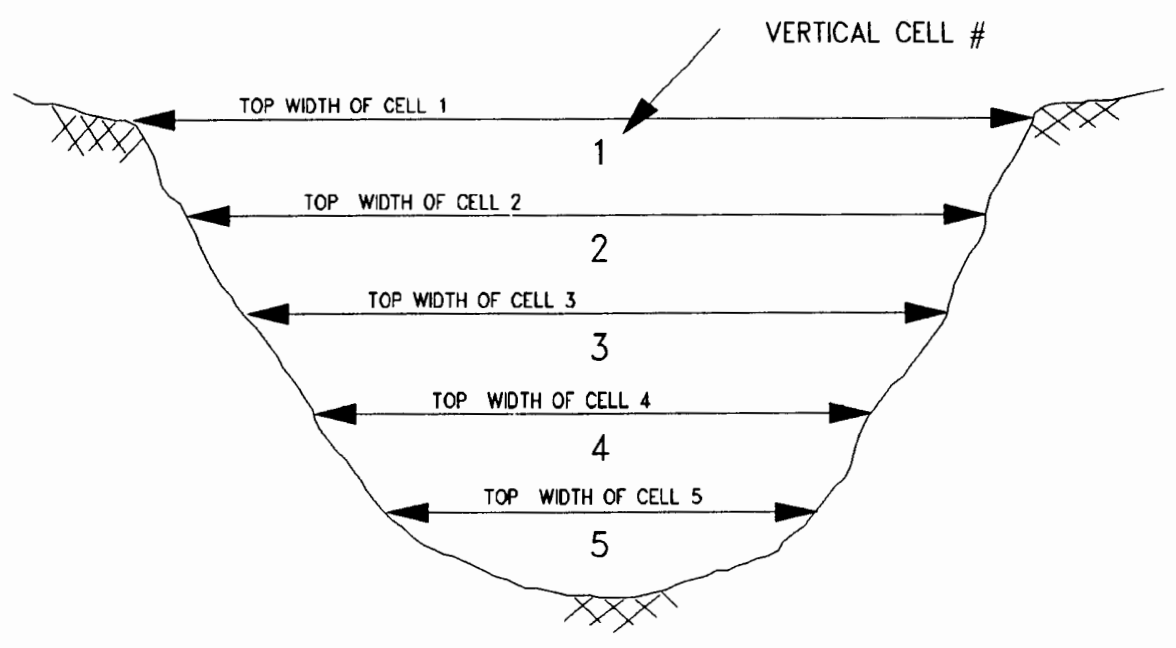

Figure 8. Vertical cell layout at each cross-section for CE-QUAL-W2 model.

into the channel widths used by CE-QUAL-W2, and then interpolating between known cross-sections to estimate river bathymetry for cells where cross-sectional data were nonexistent.

The first step in transforming the bathymetry data into the format used by CE-QUAL-W2 required establishing the mean sea level elevations of the cross-sections. When the crosssections were obtained, they were identified by river mile and water depths at various distances across the river channel. In order for the cross-sectional data to be useful to the model, it was necessary to find the actual MSL 


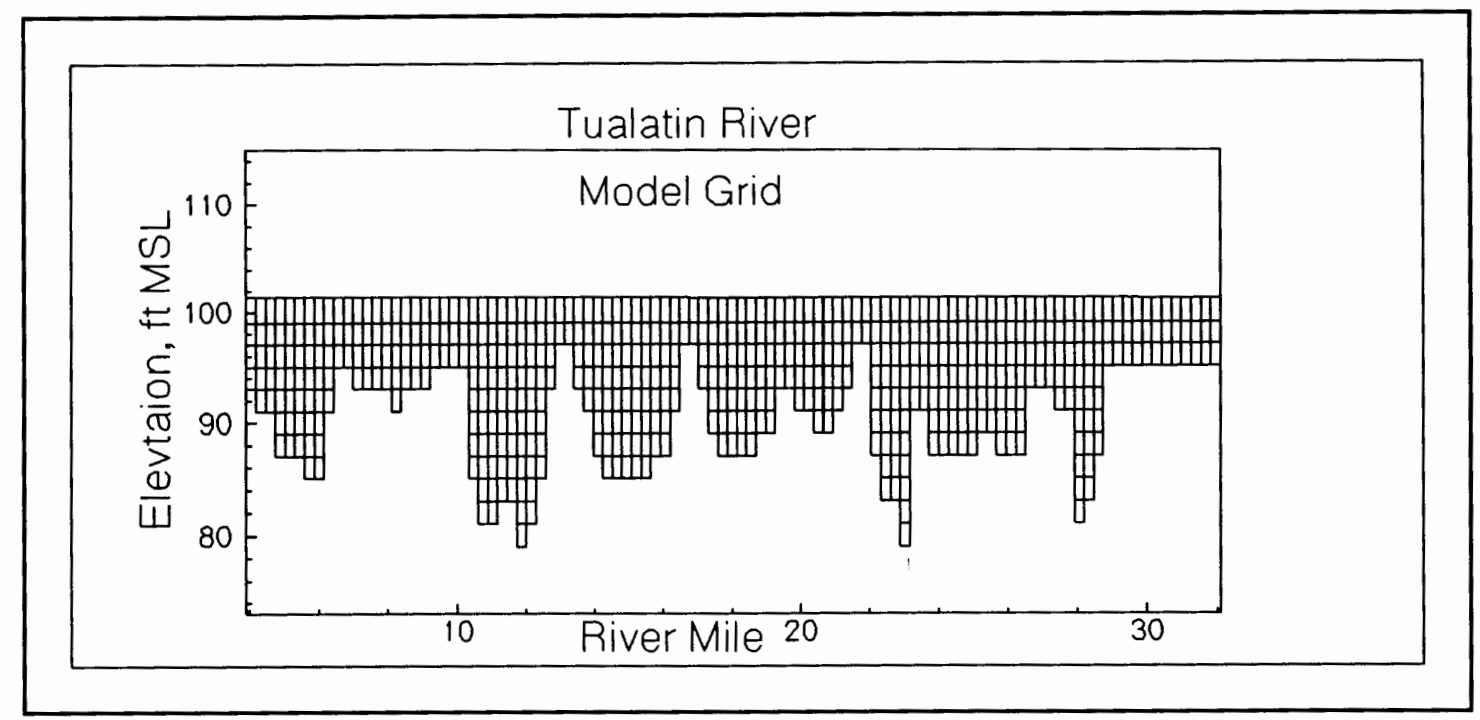

Figure 9. Approximate representation of the computational grid for the Tualatin River pool model.

elevations of the river bottom. These elevations were obtained by first finding the MSL elevation of the water surface at the time a cross-section was measured and subtracting the depths.

Once the MSL elevations of a cross-section were determined, the cell widths of the vertical layers composing the model's grid were computed. The cell width is the distance across a river channel at the top elevation of a vertical layer. A computer program calculated the cell width for each layer at a particular longitudinal cell.

Not every longitudinal cell in the model's grid had a measured cross-section which could be used to determine its bathymetry. Interpolation between longitudinal cells was performed where cross-sectional data were not available. A computer algorithm was used to generate a bathymetry file 
which was compatible with CE-QUAL-W2 .

\section{Initial conditions}

At the start of the evaluation period, the model was assigned initial conditions for the water surface level, temperature, and the constituent concentrations. The initial water surface profile was typical of late spring conditions. Initial constituent concentrations and temperature were constant throughout the model's domain and were developed from sampling data.

\section{Boundary Conditions}

The two-dimensional laterally averaged CE-QUAL-W2 model has four boundaries, two bracketing the vertical domain and two surrounding the horizontal. The upstream and downstream ends employ longitudinal flow boundary conditions. Input files incorporating inflow rates, temperatures, and constituent concentrations were used for the upstream boundary. Outflow rates for the downstream boundary were calculated using the diversion dam algorithm described below. Model boundaries representing the river bottom and water surface utilize no-flux boundary conditions.

Source and Sink Terms Simulating Fluxes Across Boundaries

Although the river bottom and water surface represent no-flux boundary conditions, the transport of water, constituents and heat across model boundaries was simulated through the governing equations' source/sink terms. 
Tributary inflows and irrigation withdrawals of water and the constituents were modeled by source/sink terms located in the advection-diffusion equation, the free water surface elevation equation, and the continuity equation. The advection-diffusion equation's source/sink term was also used to simulate the reaeration of dissolved oxygen across the air-water interface, the exchange of heat through the water surface, the adsorption of solar radiation in the water column, and the settling out of suspended solids (algae, detritus, and inorganic suspended solids) to the river bottom. The weather driven phenomena were modeled with the aid of meteorological input files consisting of air temperature, dew point temperature, cloud cover, wind speed, and wind direction.

\section{NUMERICAL SOLUTION}

The water surface elevation was computed using an implicit, space-staggered, finite difference solution algorithm to approximate the governing partial differential equations. The equations governing temperature and the constituents were solved using a Crank-Nicholson, quadratic upstream differencing algorithm (Leonard, 1979). The calculation of model variables at a succeeding time step began by determining the water surface elevation, which could be calculated given the current time step's water surface elevation and horizontal velocities. With the next 
time step's water surface elevation, the new horizontal velocities could be calculated. This was followed with the calculation of the vertical velocities using the continuity equation and the calculation of constituents and temperature using the advection-diffusion equation. This sequence was then repeated at each time step until the end of the run.

\section{DIVERSION DAM ALGORITHM}

In order to simulate the flow of water over the Lake Oswego Diversion Dam (Figure 10), a subroutine was added to the CE-QUAL-W2 program which calculated the flow over the dam and through the fish ladder given the upstream water surface elevation. Water flowing past the dam can follow three different routes: over the dam, through the fish ladder, and through a steel pipe which runs underground adjacent to the fish ladder. The algorithm differentiates between six different scenarios:

(1) the upstream water surface elevation is less than the crest of the dam, the crest of the fish ladder, and the invert elevation of the pipe, in which case the flow is zero;

(2) the upstream water surface elevation is greater than the invert elevation of the pipe, but less than the crests of the dam and fish ladder, so all flow is through the pipe; (3) the upstream water surface elevation is less than the crest of the diversion dam but greater than invert elevation 
of the pipe and the crest of the fish ladder, so flow is through the fish ladder and pipe;

(4) the upstream water surface elevation is greater than the crest of the diversion dam and the invert elevation of the pipe but less than the crest of the fish ladder, so the flow is over the dam and through the pipe;

(5) the upstream water surface elevation is greater than the invert elevation of the pipe and the crests of the diversion dam and the fish ladder, so water flows through

\section{all three;}

(6) all of the flash boards are up and the upstream water surface elevation exceeds the invert elevation of the pipe and the crests of the flash boards and the fish ladder, in which case the diversion dam functions as a sharp-crested weir rather than a broad-crested weir.

The dam and fish ladder function as weirs. With flash boards up the dam operates as a sharp-crested weir and with flash boards down it performs as a broad-crested weir. The fish ladder always functions as a sharp-crested weir. Flow through each is calculated using the following equation (Streeter and Wylie, 1985):

$$
Q=C_{w} L H^{3 / 2}
$$

Q - flow;

$C_{w}$ - weir coefficient, dependent on type of weir and geometry;

L - width of weir;

$\mathrm{H}$ - distance between weir crest and upstream surface elevation. 


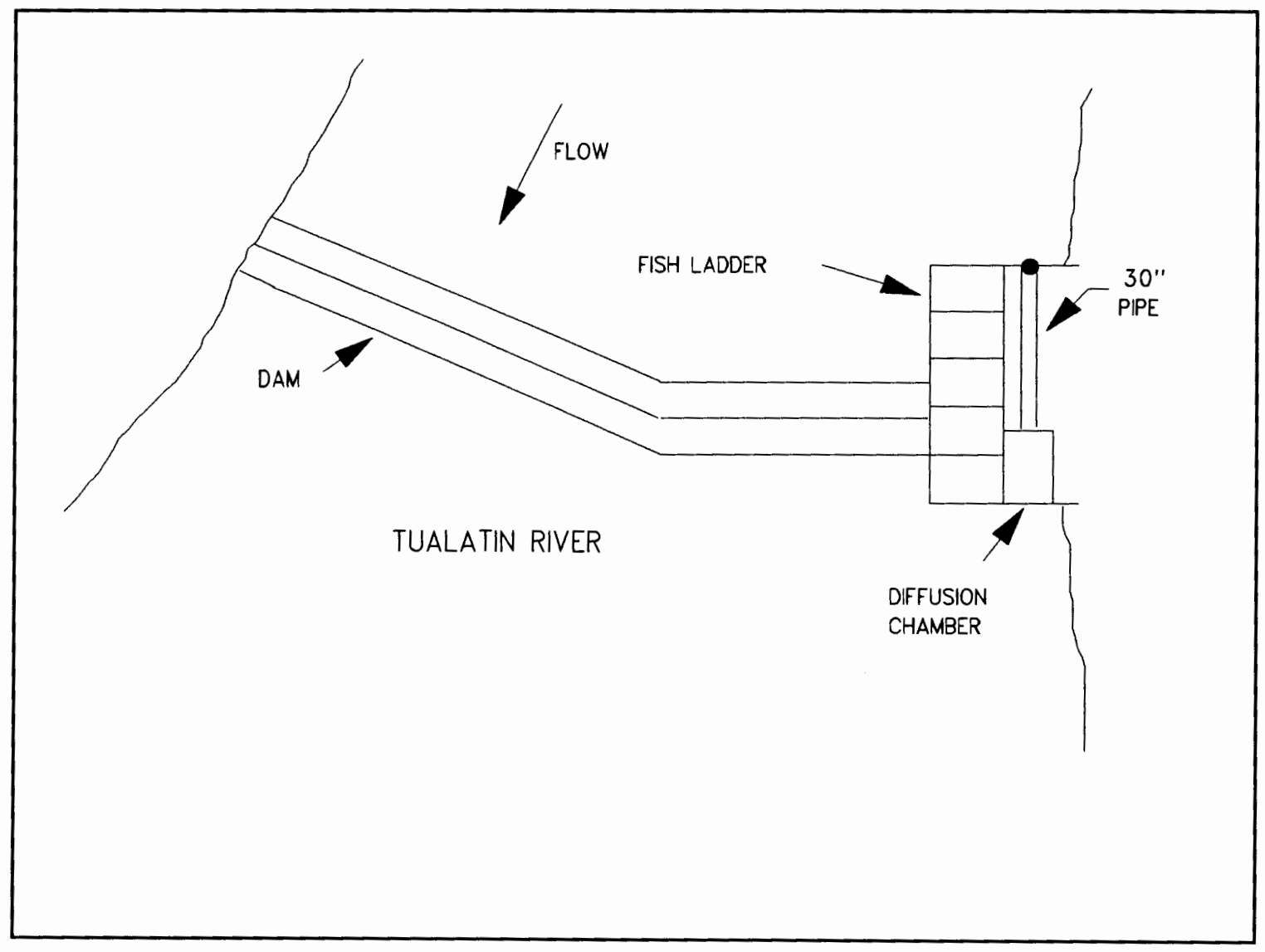

Figure 10. Sketch of diversion dam.

The weir coefficient $c_{w}$ can be expressed as

$$
C_{w}=\frac{2}{3} C_{d} \sqrt{2 g}
$$

for sharp crested weirs or

$$
C_{W}=0.385 C_{o} \sqrt{2 g}
$$

for broad crested weirs. $C_{d}$ is a dimensionless discharge coefficient. Typical values for the weir coefficient vary from 1.8 to 1.9 for sharp crested weirs and between 1.6 to 1.7 for a broad crested weir. Values of $c_{w}$ used for the fish ladder and the dam were 1.85 and 1.65, respectively. 


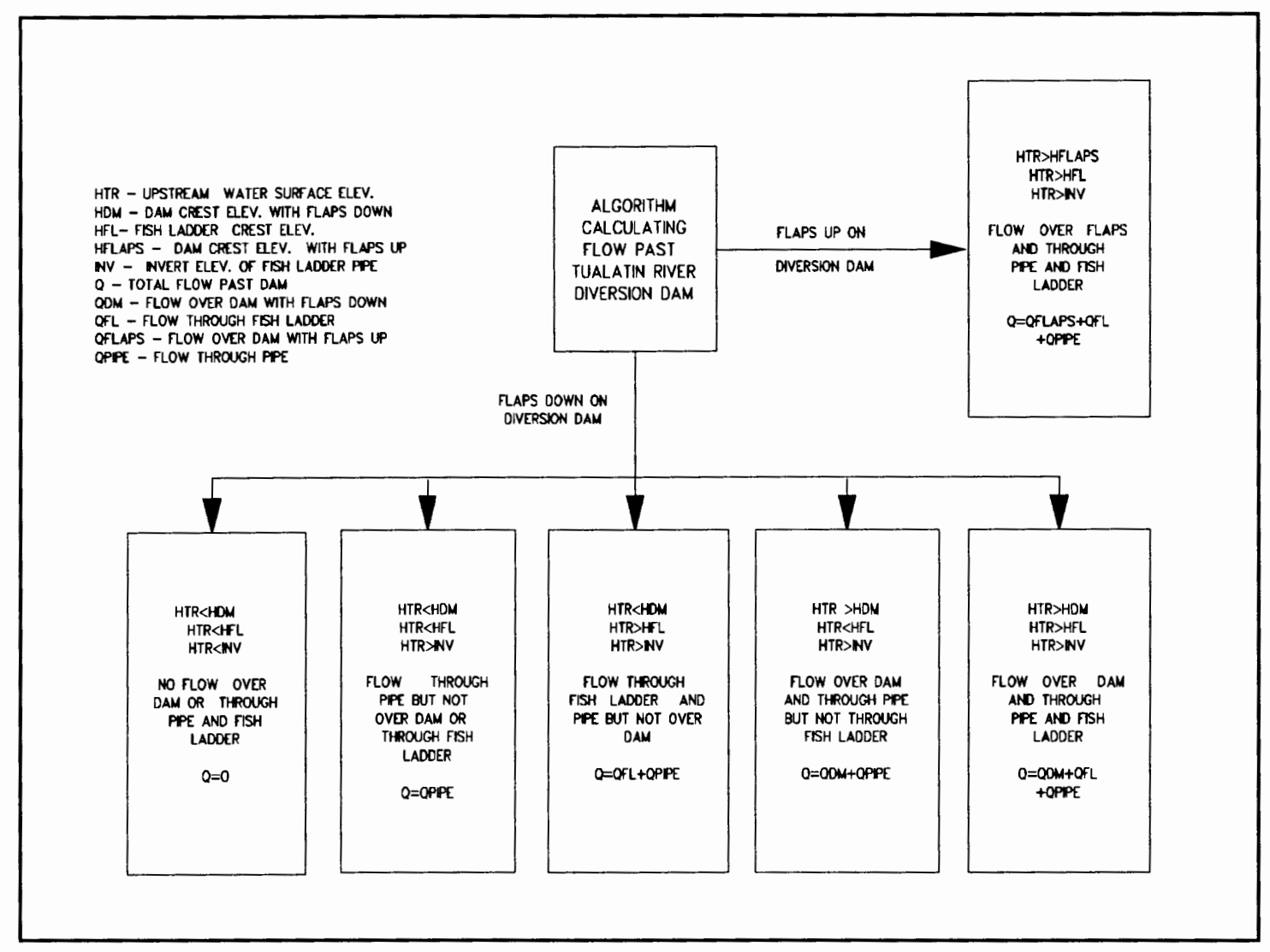

Figure 11. Flowchart showing diversion dam algorithm.

The algorithm calculating flow over the diversion dam is shown in Figure 11.

Water passing through the pipe is modeled as steady closed-conduit flow. An energy balance is used to calculate the flow. Consideration is given to changes in potential and kinetic energy along with frictional losses. The energy balance between the upstream and downstream sides of the dam is expressed in the following relation

$$
H_{1}=H_{2}+\frac{\left(\frac{Q}{A}\right)^{2}}{2 g}+K_{e} \frac{\left(\frac{Q}{A}\right)^{2}}{2 g}+\frac{R}{C^{1.852}} \frac{Q^{1.852}}{D^{4.8704}} L
$$

where 


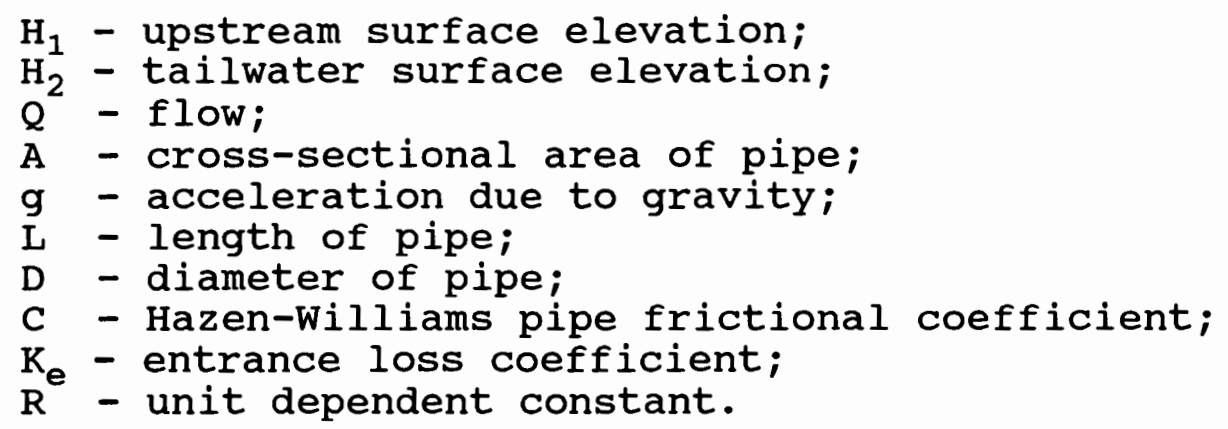

The term on the LHS of the equation and the first term on the RHS of the equation represent the upstream and downstream potential energy heads. The second term on the RHS represents the downstream velocity head, whereas the upstream velocity head was ignored because of the low flow velocities in the pool above the dam. Entrance losses are accounted for with the third term on the RHS of the equation. The entrance loss coefficient may vary widely depending on the amount of debris trapped on the grate at the pipe entrance. Typical values may be from 1 to 10 . Frictional pipe losses are represented in the fourth term on the RHS. The Hazen-Williams formula is used to estimate pipe losses, with values of $C$ for old steel ranging from 100 to 110 (Streeter and Wylie, 1983). The unit dependent constant $R$ is 4.727 for USC units and 10.675 for SI units. The downstream surface elevation, or $\mathrm{H}_{2}$, is the water level in the diffusion chamber in which the pipe empties. This can differ from the surface elevation of the river tailwater, which is connected hydraulicly to the diffusion chamber via a grate, because debris becomes trapped against 
the grate and raises the chamber's water surface several feet above the river. The water surface elevation of the diffusion chamber was observed and the elevation of the top of the pipe outlet was chosen as a reasonable estimate. 
CHAPTER IV

MODEL CALIBRATION AND VERIFICATION

\section{INTRODUCTION}

The calibration of the Tualatin River pool model was a process whereby model predictions of hydrodynamics (water surface elevations and flow rate), temperature, and water quality constituents, were compared with field data after adjusting model parameters. The period of calibration was June through August of 1991. The period of verification was June through August of 1990. The year 1991 rather than 1990 was chosen as the calibration year because of its more extensive sampling record. The 1991 sampling data included $\mathrm{pH}$ and temperature measurements along with constituent concentrations of dissolved oxygen, chlorophyll a, chemical oxygen demand, ortho-phosphate, ammonia nitrogen, nitrite/nitrate nitrogen, total suspended solids, and total dissolved solids. Vertical profiles of temperature, dissolved oxygen and $\mathrm{pH}$ were also available in 1991. In contrast, the 1990 sampling data lacked the vertical profiles and consistent chemical oxygen demand data. 


\section{CALIBRATION OF HYDRODYNAMICS}

The hydrodynamics of the pool model were calibrated using flow and water level data. Flow data were available at the west Linn stream gaging station at river mile 1.5 and water level data were available on the Tualatin River at the Lake Oswego Canal (Figure 12). The West Linn flow data were selected as an adequate approximation of flow over the diversion dam because of its relative proximity downstream from the dam (2 river miles). There are no significant summer tributary inflows between the diversion dam and gaging station. The model parameters used to calibrate the hydrodynamics were Manning's friction factor and the dam width. The dam width varied with respect to the number of flash boards which were raised. During the low flow months of the summer, water levels in the pool region of the river are mostly controlled by the width and crest elevation of the diversion dam. Notes containing information about the raising of the dam flaps throughout the summer of 1991 were obtained from the United States Geological Survey, greatly aiding the calibration process. To help correctly time model predicted flow peaks and troughs with flow measurement data, the bottom friction, or Mannings friction factor, was varied. The code is flexible enough to allow individual friction values for each longitudinal cell. If the chosen values were too high, water surface elevations would increase in response to the decreased horizontal velocities, 


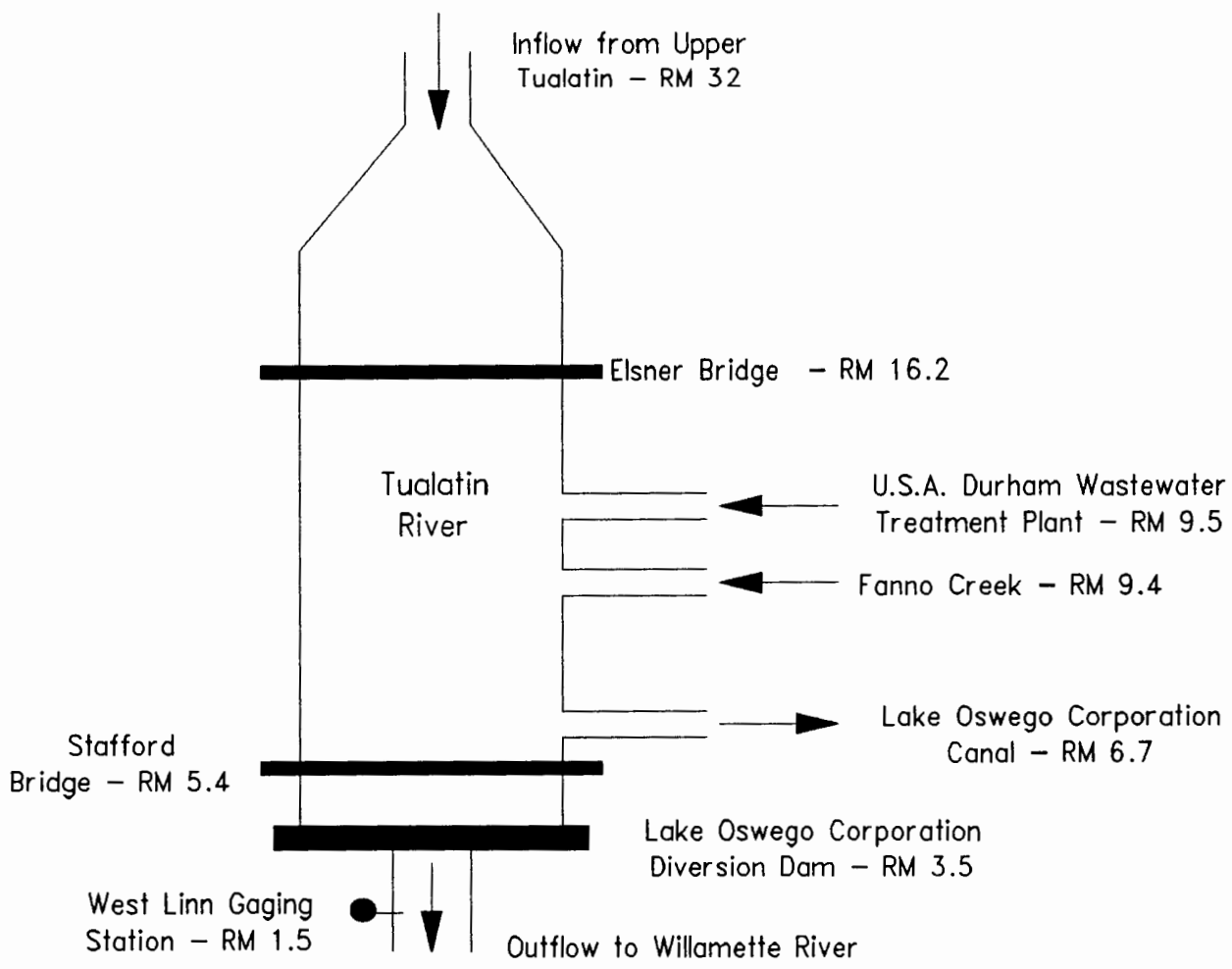

Figure 12. Schematic illustrating lower Tualatin River.

producing greater river volumes and larger detention times. This would cause the model predicted flow peak to arrive later than the proper time. If the Mannings friction factors were too low, the opposite would occur. The selection of correct bottom friction values were most critical during the early summer when flows were still relatively high and the water levels were less dependent upon the diversion dam.

As can be seen in Figure 13, a fairly close match between model predictions and data was obtained for water surface elevation and flow. These close fits were attained 
despite only considering inflows from Fanno Creek, the Durham sewage treatment plant and flow from the upstream boundary (flow data from Farmington gaging station was used). To help account for early summer inflows from minor tributaries and groundwater, a 70 cfs distributed inflow was included, but this was discontinued after Julian Day 200 . Thus, after Julian day 200 the close fit between the simulation and data was attained despite only considering inflow from the upstream boundary, Fanno Creek, and USA Durham. Apparently the summer groundwater inflow was balanced by irrigation withdrawals. A Mannings friction factor of 0.035 was selected as an appropriate value for all longitudinal cells. This value helped correctly time flow maxima and minima and is fairly representative of rivers similar to the Tualatin (Henderson, 1966).

Figure 14 shows the model predicted shift of the water surface profile during calibration run. In the late spring and early summer, the pool area of the Tualatin had a profile which was representative of a river rather than a reservoir. As the river flow decreased through the summer, the water surface profile became flatter, and the lower Tualatin became more like a lake. 

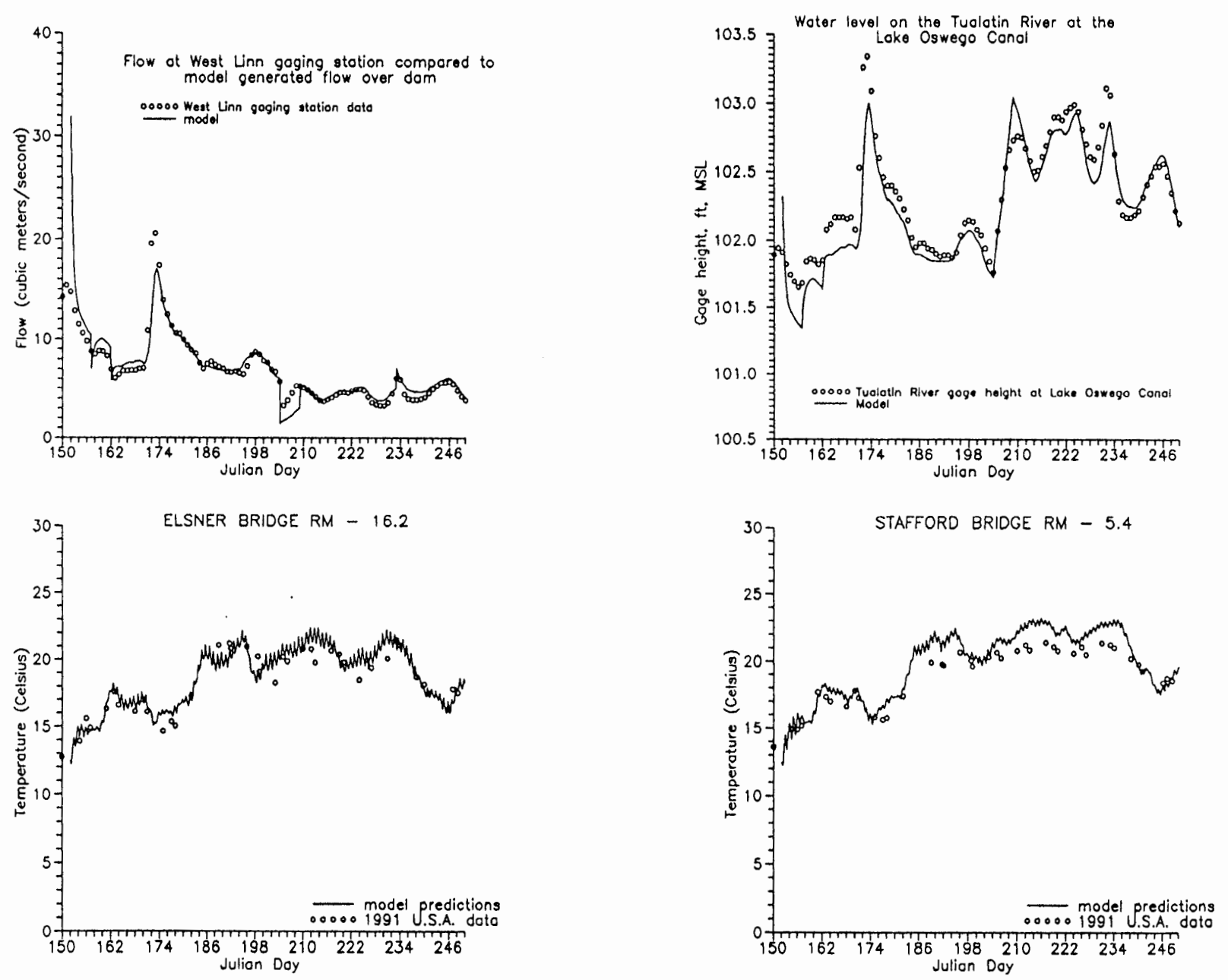

Figure 13. Calibration results for flow, water surface elevation, and temperature is 
1991 Model Predicted Water Surface Profiles

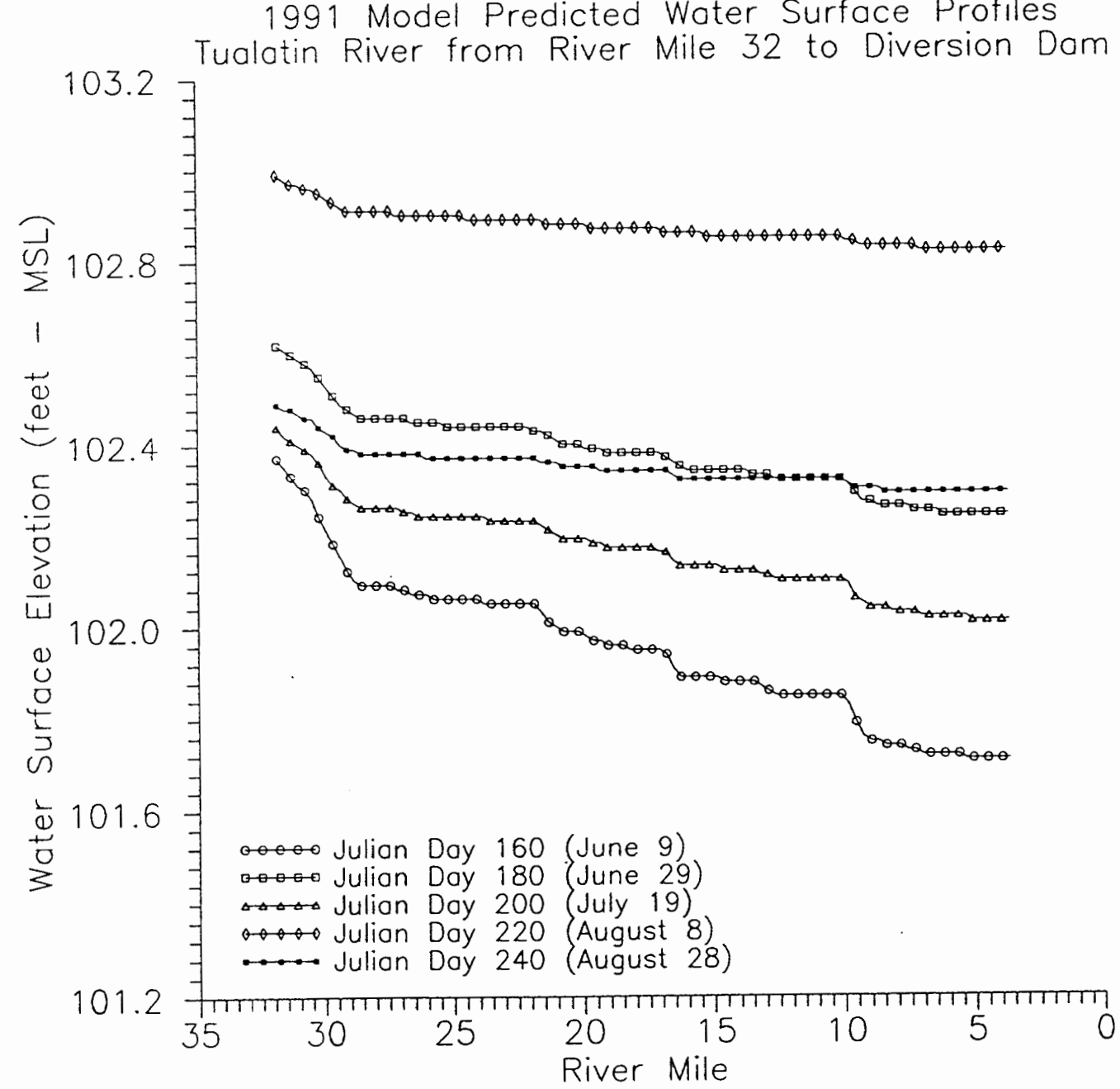

Figure 14. Model predicted water surface profiles for 1991. 


\section{TEMPERATURE CALIBRATION}

Water temperature was calibrated using USA sampling data at Elsner and stafford. These sampling data included temperature versus depth profiles which allowed the comparison of actual and model predicted stratification. Because of the lack of consistent temperature data immediately above the beginning of the pool model (river mile 32), inflow temperatures were estimated using temperature data obtained at Scholls bridge (river mile 26.9), which is located within the model, 5 miles downstream from the upstream boundary. Given the water temperatures at Scholls, the inflow temperatures at the beginning of the model were back-calculated. The primary parameter used in the water temperature calibration was the wind sheltering coefficient, although the vertical diffusion parameter was also varied. The model predictions were fairly close to the data at Elsner but were higher than the data at stafford (Figure 13). Figures 15 and 16 show vertical profiles of temperature at stafford and Elsner on selected days in the calibration run. It is curious that the sampling data shows only a small difference in temperature between Elsner and Stafford, even though stafford is 11 miles further downstream. In the summer months it seems reasonable that further heating may occur in the slow moving river stretch between Elsner and Stafford, and the model predicts a 
temperature increase. The discrepancy may be partially the result of the model using only one wind sheltering coefficient. Wind sheltering is a parameter that is dependent on river width and bank vegetation, and the model uses a constant value for all longitudinal cells rather than assigning a particular value for each river segment. Above Elsner, the Tualatin River is narrow and meandering, but between Elsner and stafford it begins to straighten and become wider. The increased fetch length and less wind sheltering below Elsner may allow wind to affect the water surface more than above Elsner, producing greater cooling. 

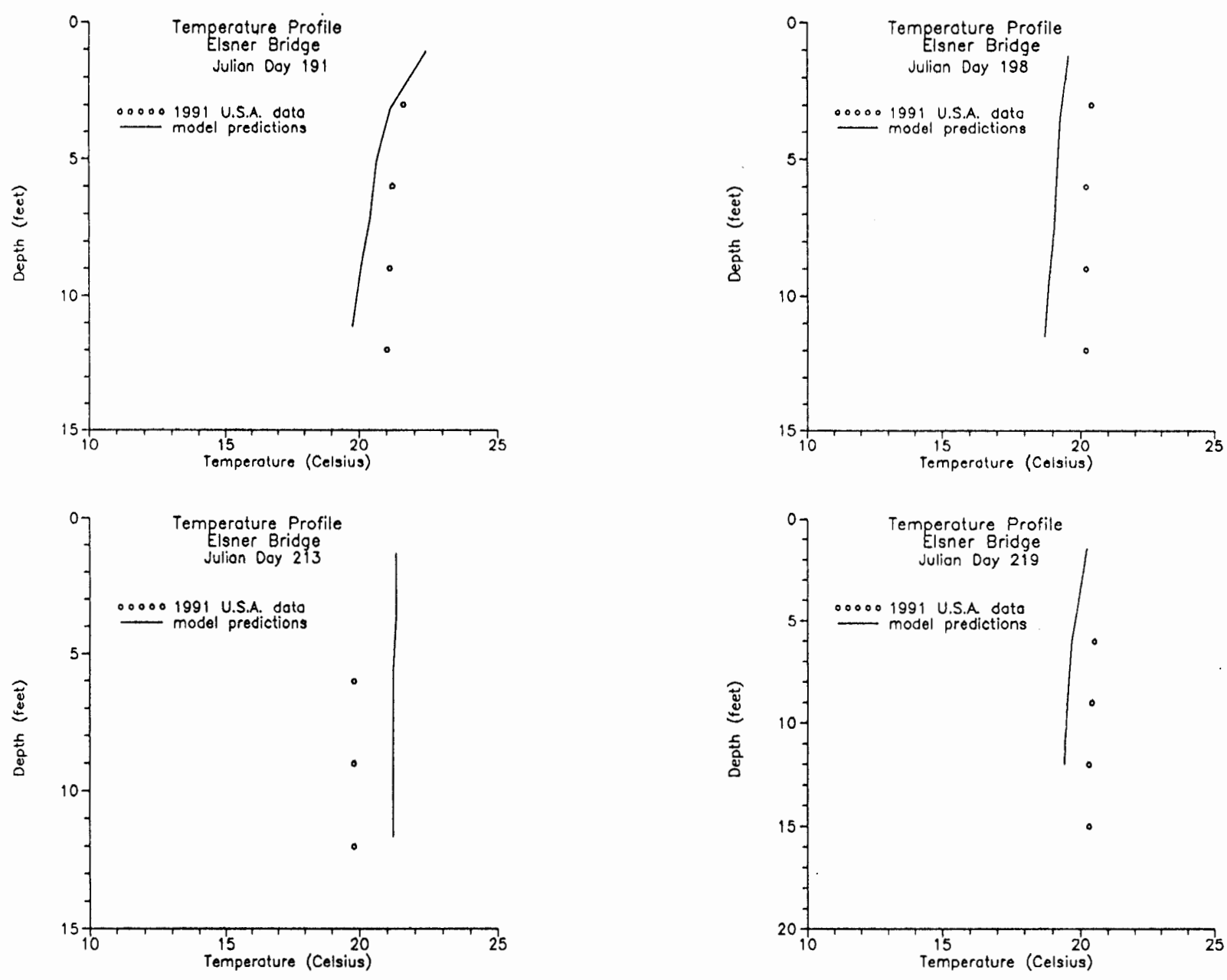

Figure 15. Calibration results for temperature stratification at Elsner Bridge. 

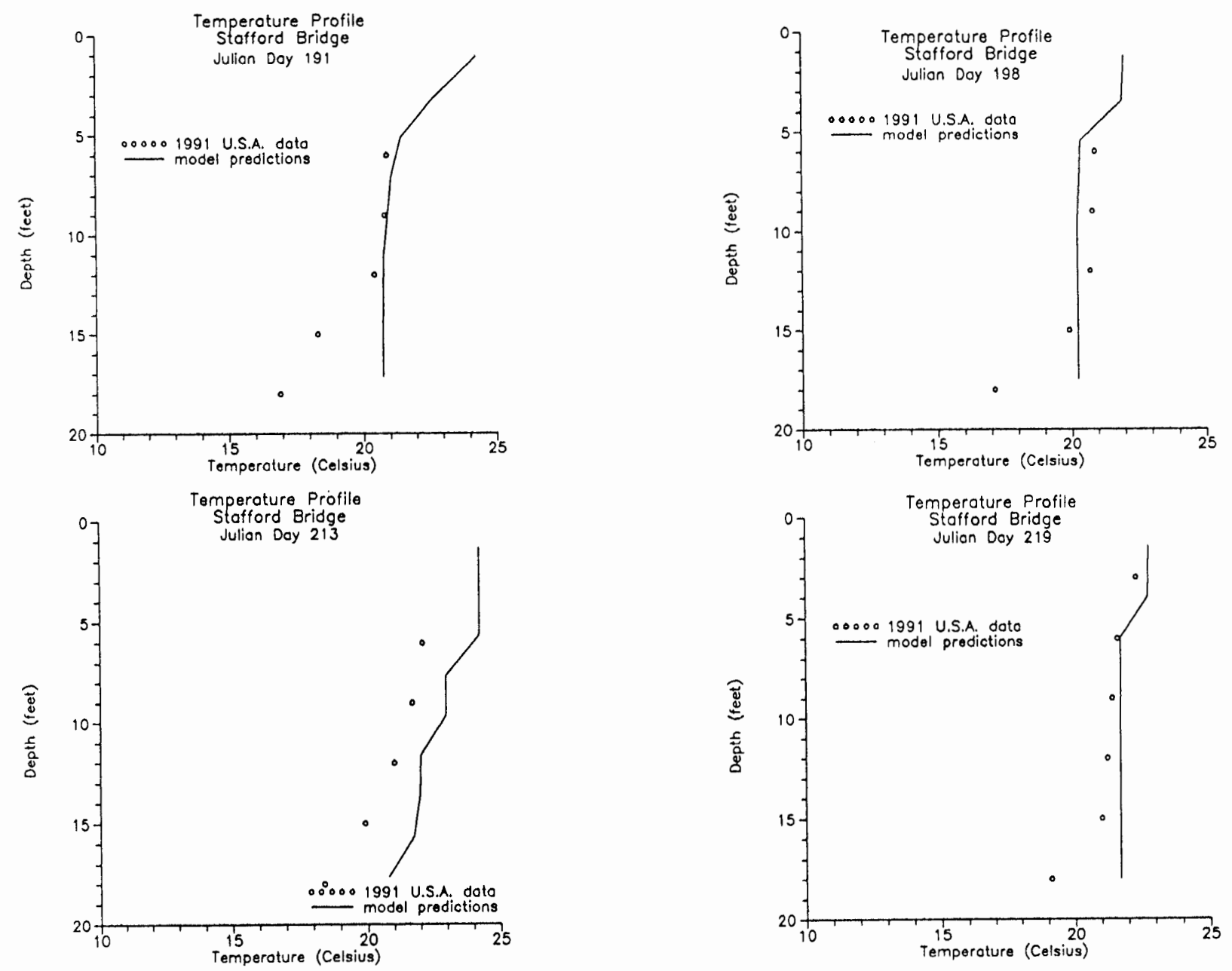

Figure 16. Calibration results for temperature stratification at stafford Bridge. 
CONSTITUENT CALIBRATION

Constituent calibration was accomplished by comparing USA sampling data at Elsner Bridge and Stafford Bridge with model predictions (Figures 17 to 24). Elsner and Stafford were selected as calibration points because of the extensive sampling record at those locations. These data records included frequent sampling along with vertical profiles of DO, pH, and temperature. Elsner and Stafford were also ideally situated within the pool. Stafford, located at river mile 5.4 , is representative of water quality conditions immediately above the diversion dam and below the Durham Treatment Plant, while Elsner, at river mile 16.2 , is more representative of meandering regions of the pool above the Durham Treatment Plant. The sampling data used to calibrate the model consisted of a vertical average of concentration in the first 10 feet of water below the surface. Model predicted concentrations are also a vertical average through approximately the first 10 feet of depth. Constituent calibration was an iterative process involving varying model parameters while also estimating constituent inflow concentrations for which sampling data were unavailable.

\section{Upstream Boundary}

Input constituent concentrations for the upstream boundary were formulated using USA sampling data from 
Scholls Bridge and inferences drawn from these data. Scholls bridge sampling data were selected for the inflow file because of the proximity of scholls bridge to the pool models upstream boundary and the availability of sampling data at this location. Scholls bridge sampling data were used to create the constituent inflow file along with concentration estimates of zooplankton, labile BOD, refractory BOD, detritus, inorganic carbon, algae, and alkalinity.

Inflow concentrations for labile BOD, refractory BOD, and detritus were estimated using COD (chemical oxygen demand) concentrations acquired through USA sampling. As suggested by the USGS, ultimate BOD concentration was calculated using a supposed 10:1 ratio between COD and ultimate BOD. Labile BOD, refractory BOD, and detritus concentrations were then estimated by taking $80 \%, 10 \%$, and $10 \%$, respectively, from the ultimate BOD.

Inorganic carbon and alkalinity concentrations were estimated using the $\mathrm{pH}$ data that were available at Scholls bridge. For the first calibration run, a reasonable alkalinity concentration was assumed, and the inorganic carbon was calculated using the known $\mathrm{pH}$ and the assumed alkalinity. After the model run, the predicted $\mathrm{pH}$ was compared with the $\mathrm{pH}$ sampling data at Elsner and Stafford. If more or less buffering was required, the inorganic carbon and alkalinity concentrations were adjusted accordingly, 
though the $\mathrm{pH}$ determined through sampling at Scholls was still maintained.

The algal inflow concentrations were estimated from chlorophyll a sampling data. The model uses algal concentrations in $\mathrm{mg} / \mathrm{l}$, and a microgram per liter chlorophyll a to milligrams per liter wet algae ratio of 37.5 was used to estimate the algal inflow concentrations.

Zooplankton inflow concentrations were estimated by inferring their grazing effect on algal concentrations. For the summer of 1991, there were several late summer algal blooms which occurred at Elsner but seemed to dwindle when they reached stafford. Early summer algal blooms, in contrast, were larger at stafford than at Elsner. It had been observed by the USGS that zooplankton were more prevalent in the lower pool area near stafford than upriver. A fairly close fit for chlorophyll a concentration was obtained at Elsner and stafford by adjusting the inflow zooplankton concentrations so that they were small enough not to substantially effect algal concentrations at Elsner (Figure 17). The zooplankton growth rate, however, was large enough so that by the time the zooplankton population had reached stafford, further downriver, they had begun to limit the algal concentrations. This effect was restricted to the late summer by gradually increasing the zooplankton inflow concentrations through the summer (Figure 21). 


\section{Tributary Inflow Concentrations}

Constituent concentrations from tributary inflows were obtained from USA sampling data of Fanno Creek and the Durham Treatment Plant. For Fanno creek, the labile BOD, refractory $\mathrm{BOD}$, and detritus concentrations were estimated using COD sampling data (discussed above). For the Durham Treatment Plant, COD concentrations were also used to estimate total ultimate $B O D$ using a 10:1 ratio, and the total ultimate BOD was assumed to be all labile BOD.

Inorganic carbon concentrations from the Durham Treatment Plant were estimated using $\mathrm{pH}$ and alkalinity sampling data.

Constituent groundwater concentrations of phosphorous, nitrogen, and nitrates were obtained by using the informed estimates of the USGS. The concentrations were: dissolved orthophosphorous, $0.05 \mathrm{mg} / 1$; ammonia-nitrogen, $0.003 \mathrm{mg} / 1$; and nitrate-nitrogen, $0.5 \mathrm{mg} / \mathrm{l}$. The dissolved oxygen concentration of the groundwater was assumed to be $9.0 \mathrm{mg} / \mathrm{l}$.

\section{Constituent Model Parameters}

Throughout the calibration process the model constituent parameters were changed so as to achieve a best fit between model predictions and sampling data. While a range of parameter values was tried, careful attention was paid to ensure that each parameter value stayed within generally accepted ranges. These parameter ranges were either known for the Tualatin itself or were obtained from 
published sources describing similar water bodies. The reasoning behind the chosen values for a few of the parameters is discussed below. All final parameter values are listed in Table I.

Because of the close link between phytoplankton and water quality, some of the most critical parameters calibrated were the ones controlling algal dynamics. Algal growth, mortality, respiration, and settling rates strongly affected $\mathrm{pH}$ along with dissolved oxygen, nitrogen, nitrate, and phosphorus concentrations. As was done with the algae inflow concentrations, a ratio of $37.5 \mu \mathrm{g} / 1$ chlorophyll a to $1 \mathrm{mg} / \mathrm{l}$ algae was used to convert model predicted algal concentrations to chlorophyll a concentrations. An algal growth rate of $3.0 \mathrm{day}^{-1}$ seemed to provide the closest fit between model predictions and sampling data. The calibrated algal settling rate was 0.2 meters/day. It had been suggested using a settling rate of 0.5 meters/day, but it was discovered that the phytoplankton settled out faster than they could grow, causing the model to under-predict algal concentrations. Algal settling rate was varied with the goal of recreating the late summer algal blooms that existed at Elsner but had diminished by the time they had reached stafford. It was hoped that algae coming in from the upstream boundary would multiply once they entered the pool, producing a bloom when they reached Elsner, but then settling out before arriving at stafford. It was discovered 
that varying the settling rate changed the magnitudes of algal blooms at Elsner and stafford uniformly, rather than affecting the bloom more at one location than the other. As was discussed above in the section describing the upstream boundary, zooplankton growth rate and inflow concentration provided a better mechanism for influencing the relative magnitudes of the algal blooms.

The river's algal populations caused large swings in dissolved oxygen concentration. Sampling data showed that dissolved oxygen supersaturation was a frequent occurrence during the algal blooms. Unfortunately, despite a relatively high algal growth rate, supersaturation was difficult to attain because the dissolved oxygen would often equilibrate with atmosphere faster than it could be produced through photosynthesis. Consequently, the model tended to predict dissolved oxygen concentrations which were near saturation rather than above it. To better simulate the dissolved oxygen conditions which exist in the river, the interfacial exchange rate used by the model was modified. The original interfacial exchange rate used was Kanwisher's (1963) formulation

$$
E_{o}=\frac{D_{o}}{\left[200-60\left(W_{a}\right)^{1 / 2}\right] * 1 \times 10^{-6}}
$$

$D_{0}$ - molecular diffusivity of dissolved oxygen;

$\mathrm{w}_{\mathrm{a}}$ - wind speed in meters/second.

The equation was modified by multiplying it by a reducing 
factor of 0.1 . This alteration allowed the model to recreate the supersaturated conditions which occurred during the blooms (Figure 17).

Dissolved oxygen sampling data at Elsner and Stafford included vertical profiles (Figures 23 and 24 ). The profiles showed stratification which is representative of a significant sediment oxygen demand. Stratification appeared to be more substantial at Stafford than at Elsner. The model permitted different sediment oxygen demand rates to be assigned to each longitudinal cell. A sediment oxygen demand rate of $3.0 \mathrm{~g} / \mathrm{m}^{2}$-day was given to the bottom cells between the Durham Treatment Plant (RM 10.0) and Stafford Bridge (RM 5.4). All other bottom cells had SOD of 0.5 $\mathrm{g} / \mathrm{m}^{2}$-day. Although the stratification predicted by the model did not exactly fit the data, the model was able to approximately recreate the dissolved oxygen stratification. 

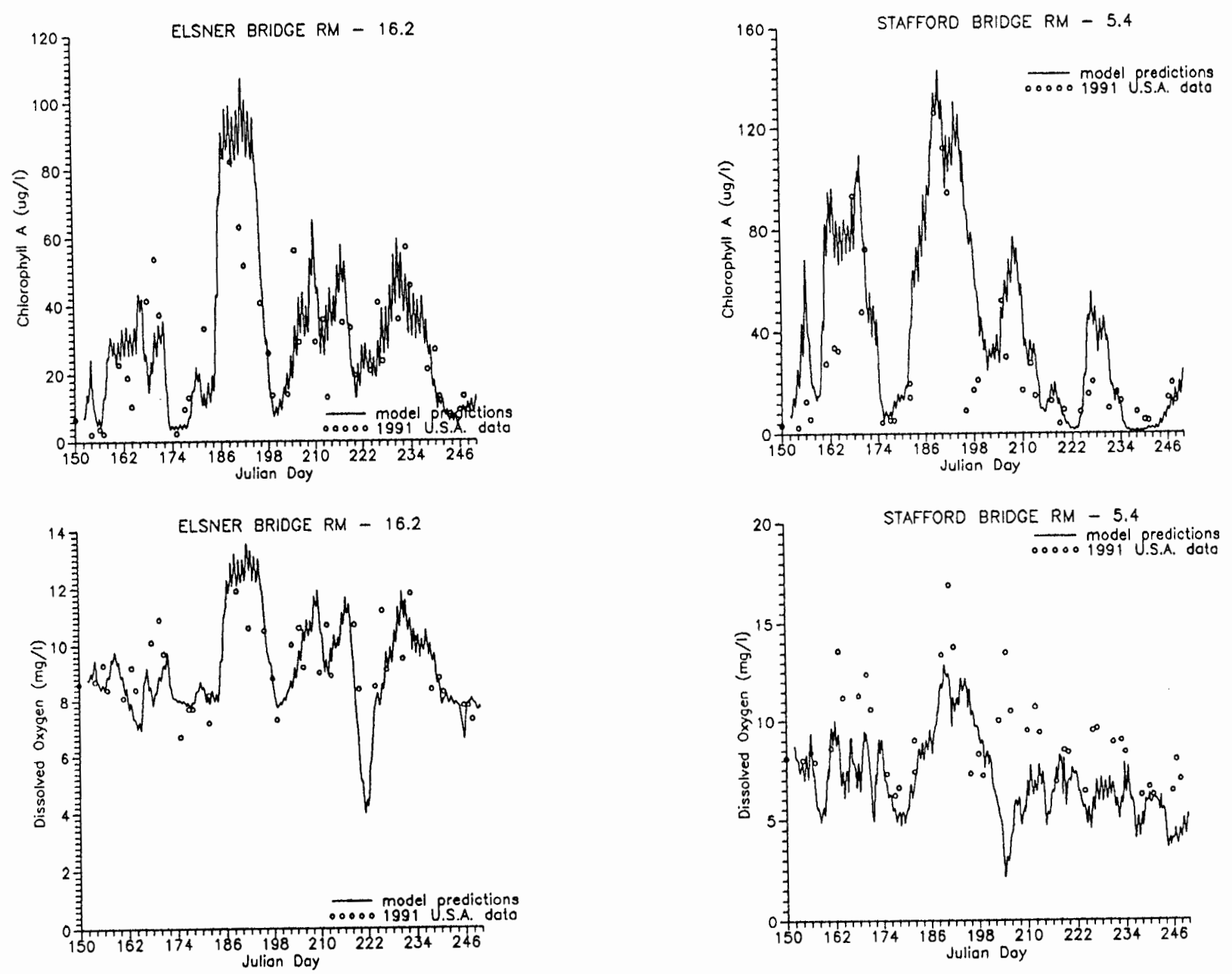

Figure 17. Calibration results for chlorophyll-a and dissolved oxygen. 

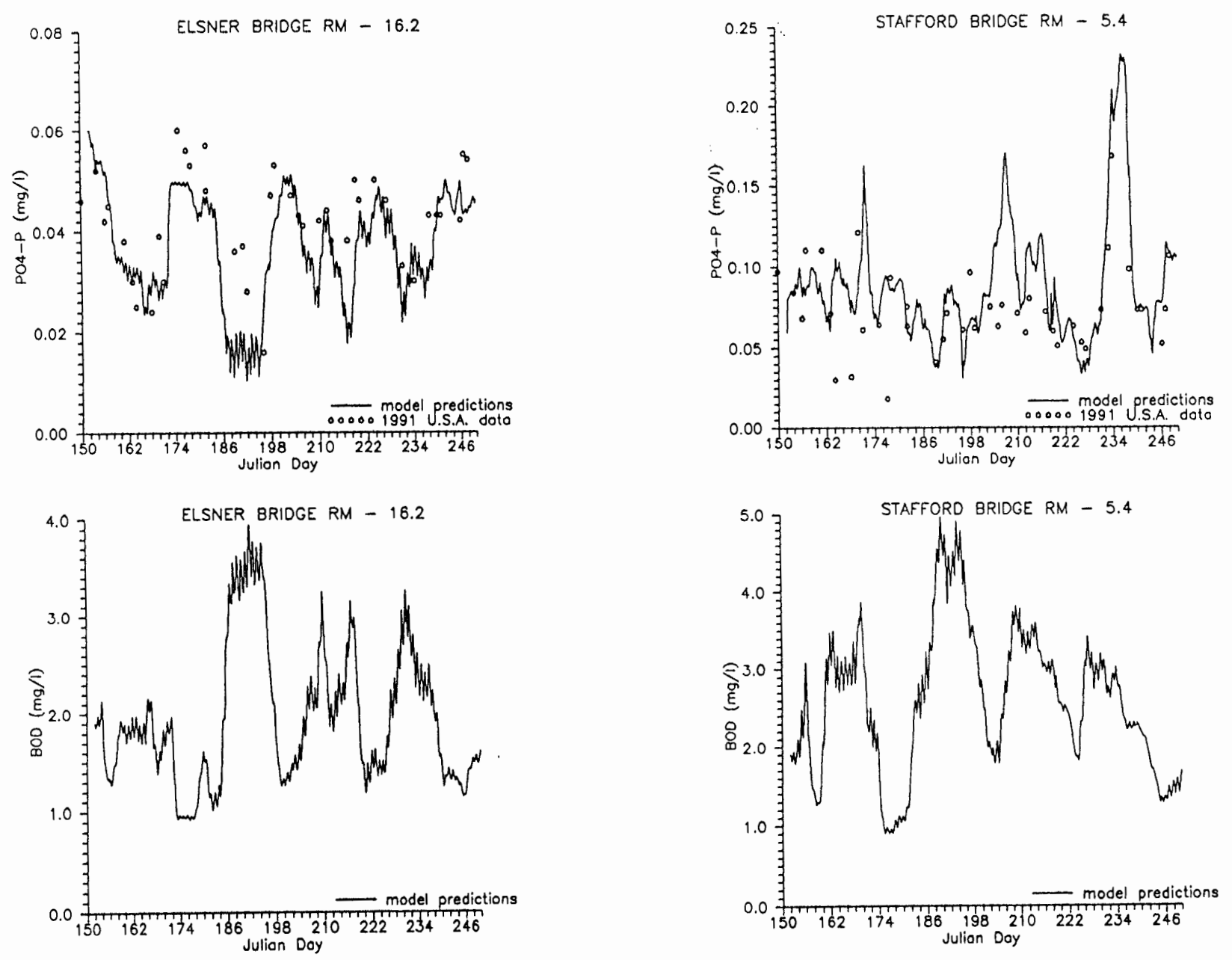

Figure 18. Calibration results for orthophosphorus and biochemical oxygen demand. 

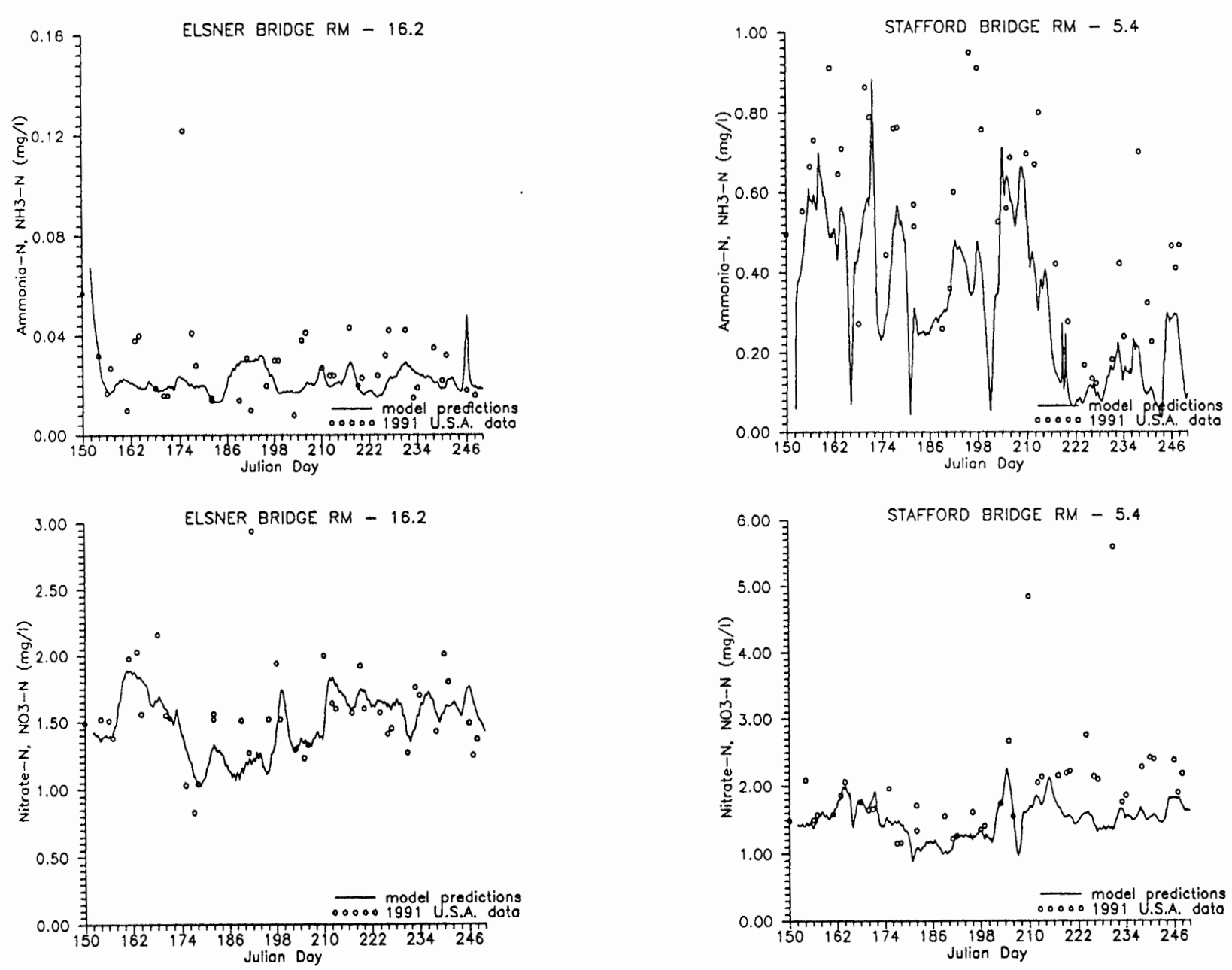

Figure 19. Calibration results for ammonia nitrogen and nitrite/nitrate nitrogen. 

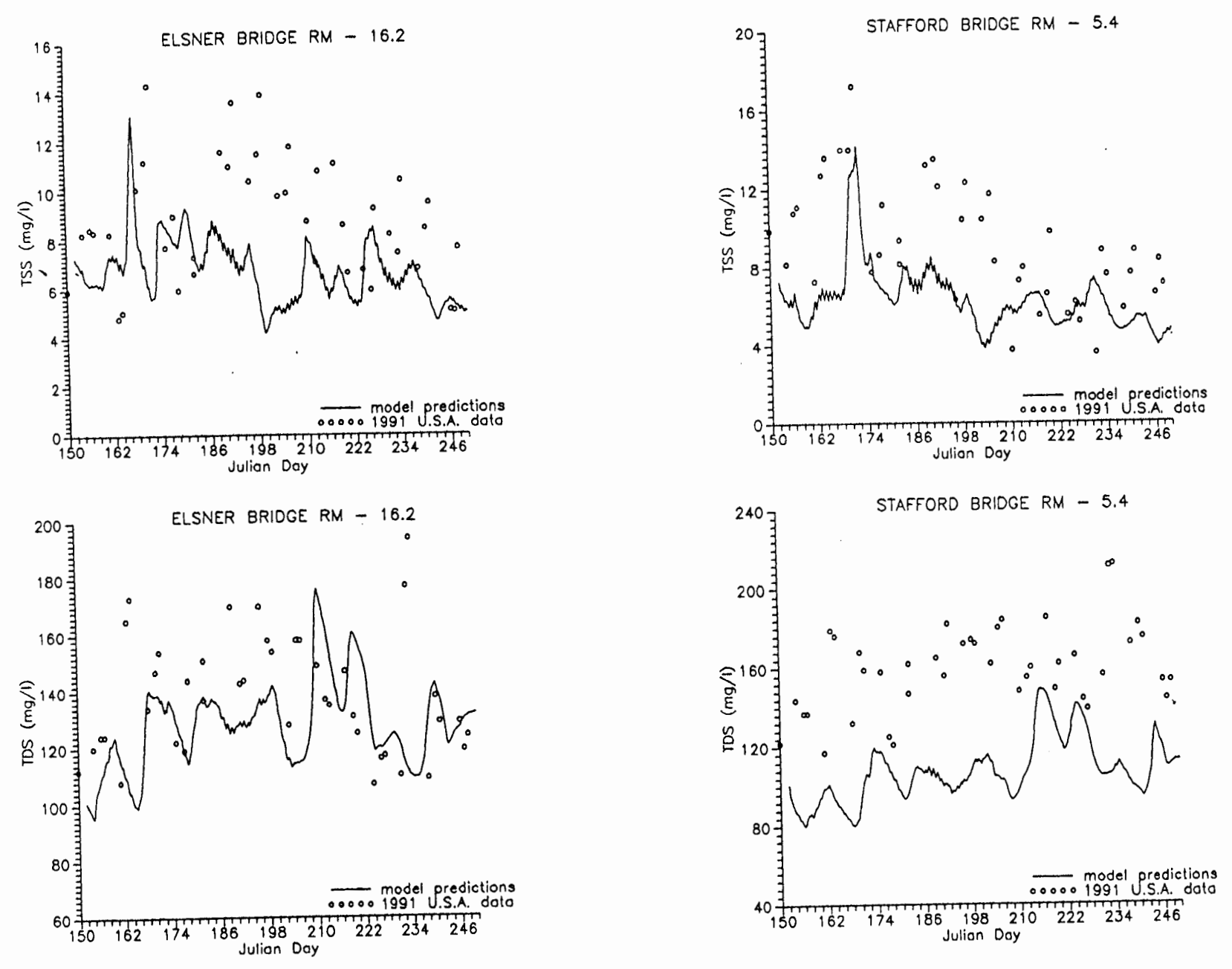

Figure 20. Calibration results for total suspended solids and total dissolved solids. 

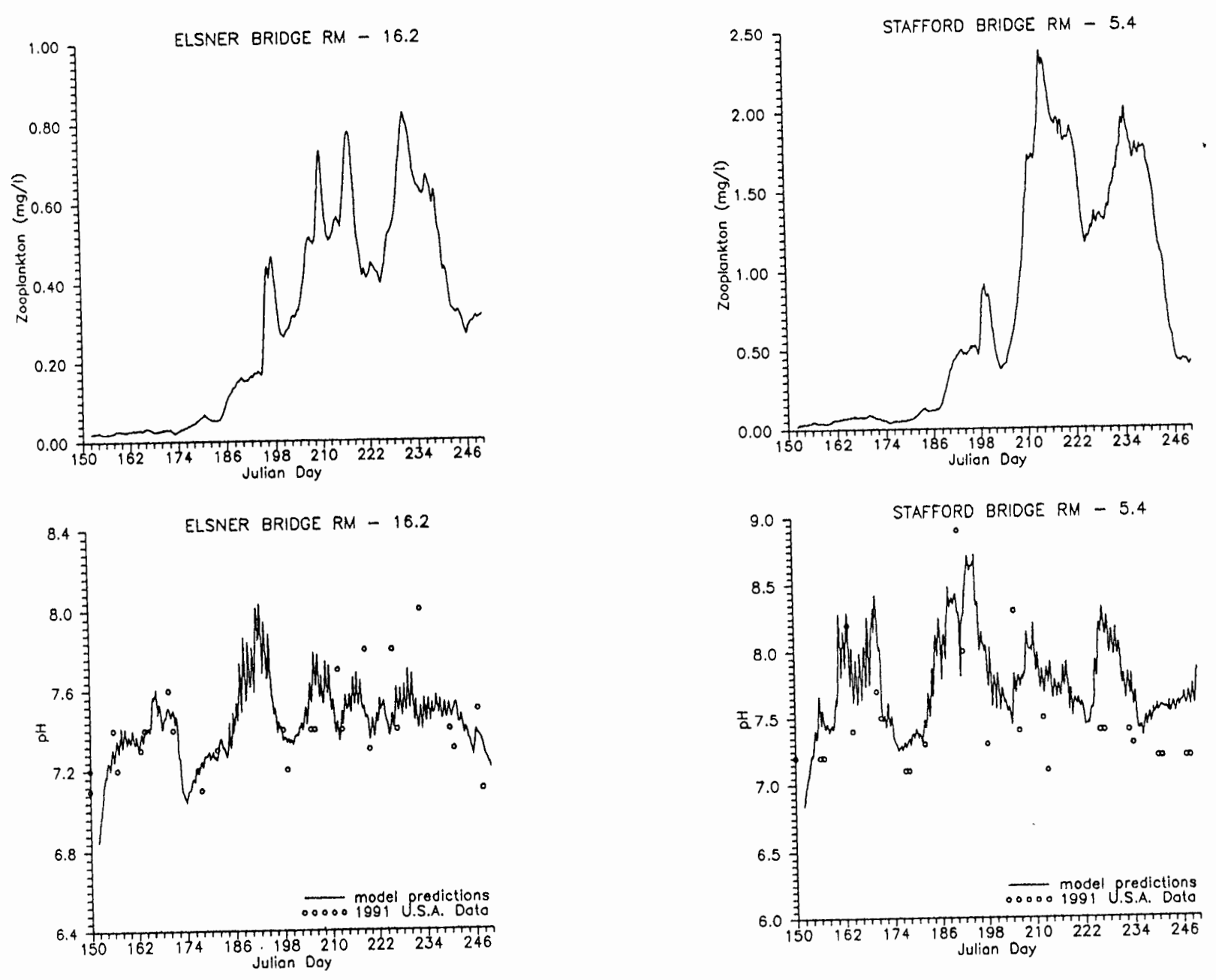

Fiqure 21. Calibration results for $\mathrm{pH}$ and model predicted zooplankton. 

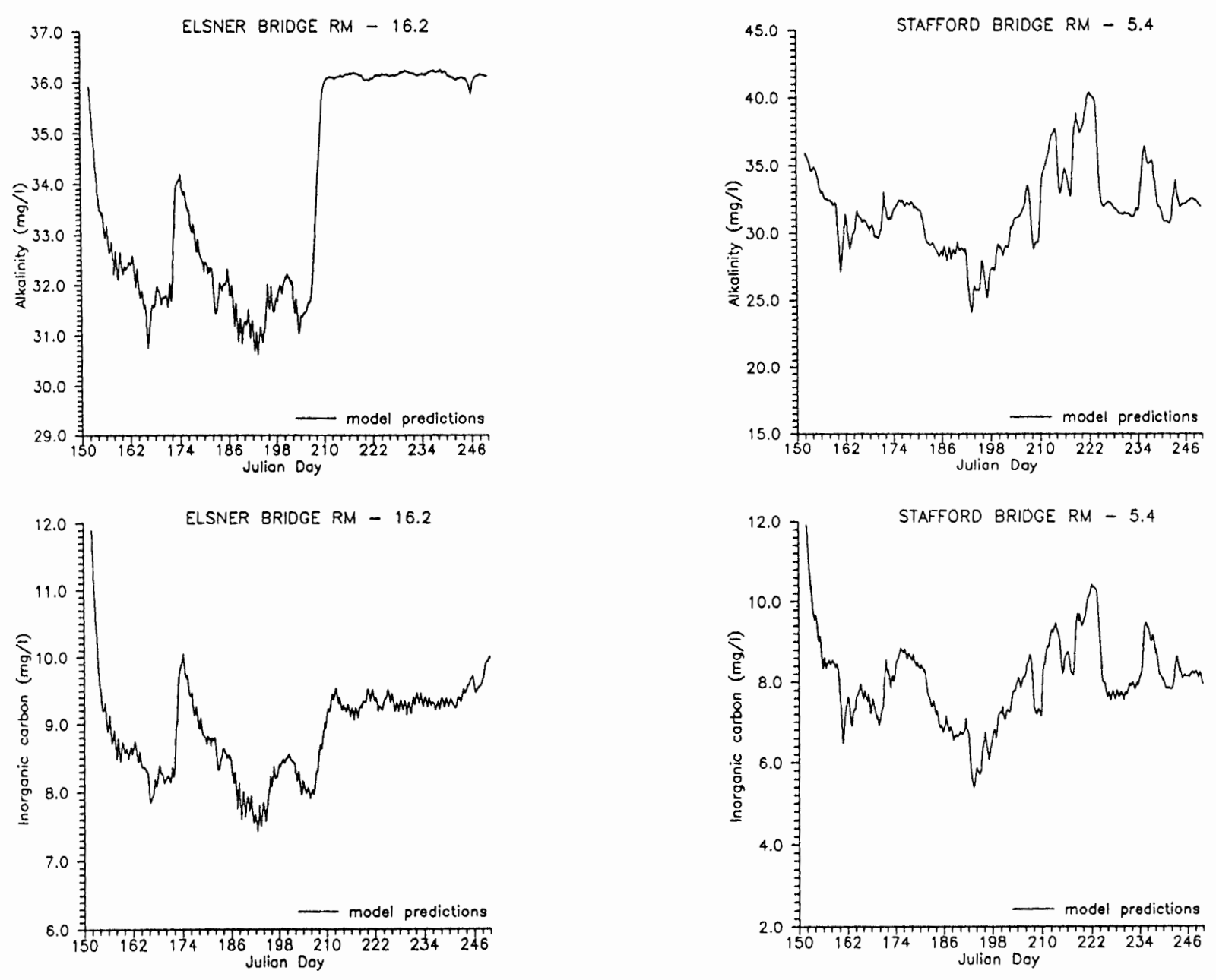

Figure 22. Model predicted alkalinity and inorganic carbon for the calibration run. 

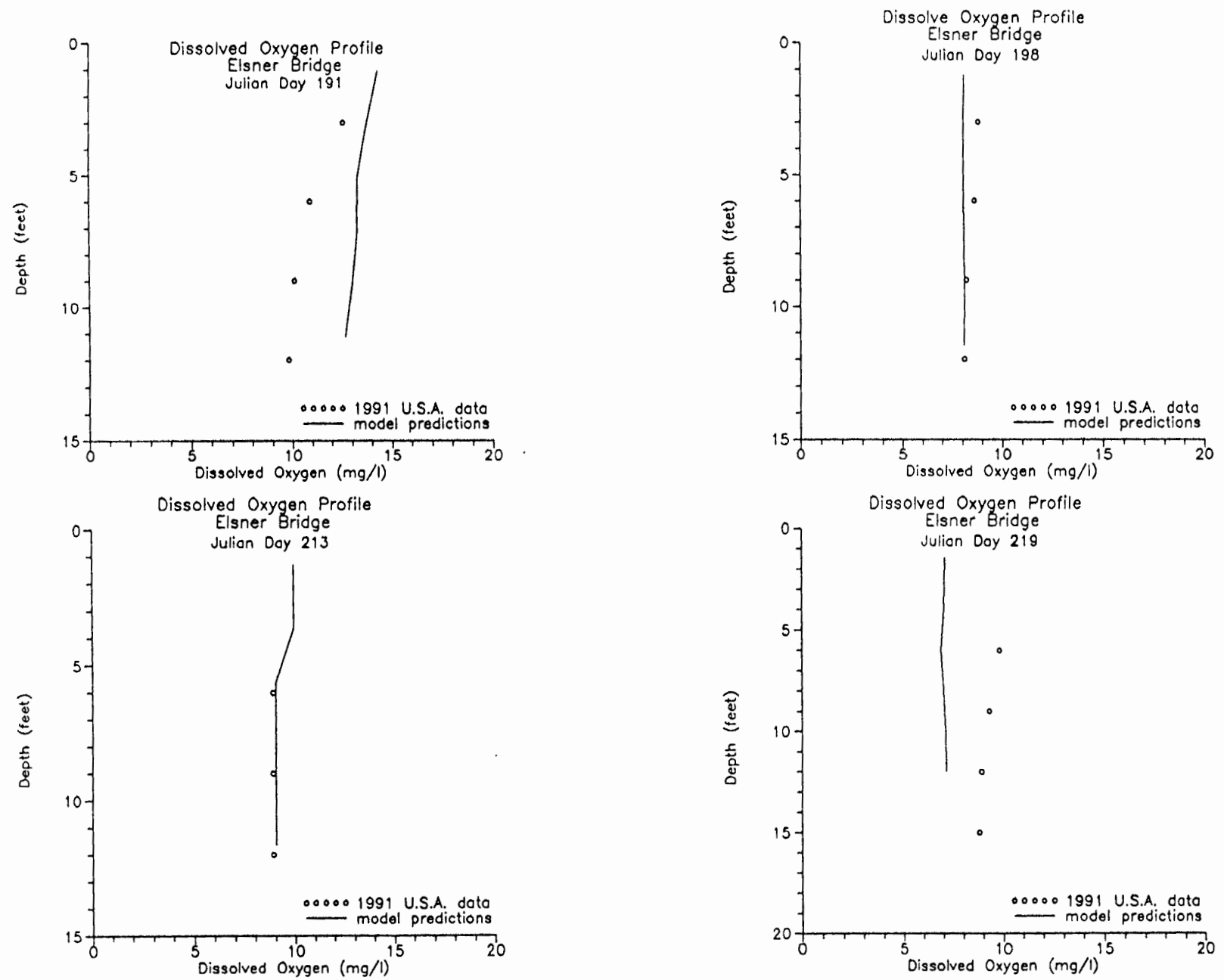

Figure 23. Calibration results for dissolved oxygen stratification at Elsner Bridge. 

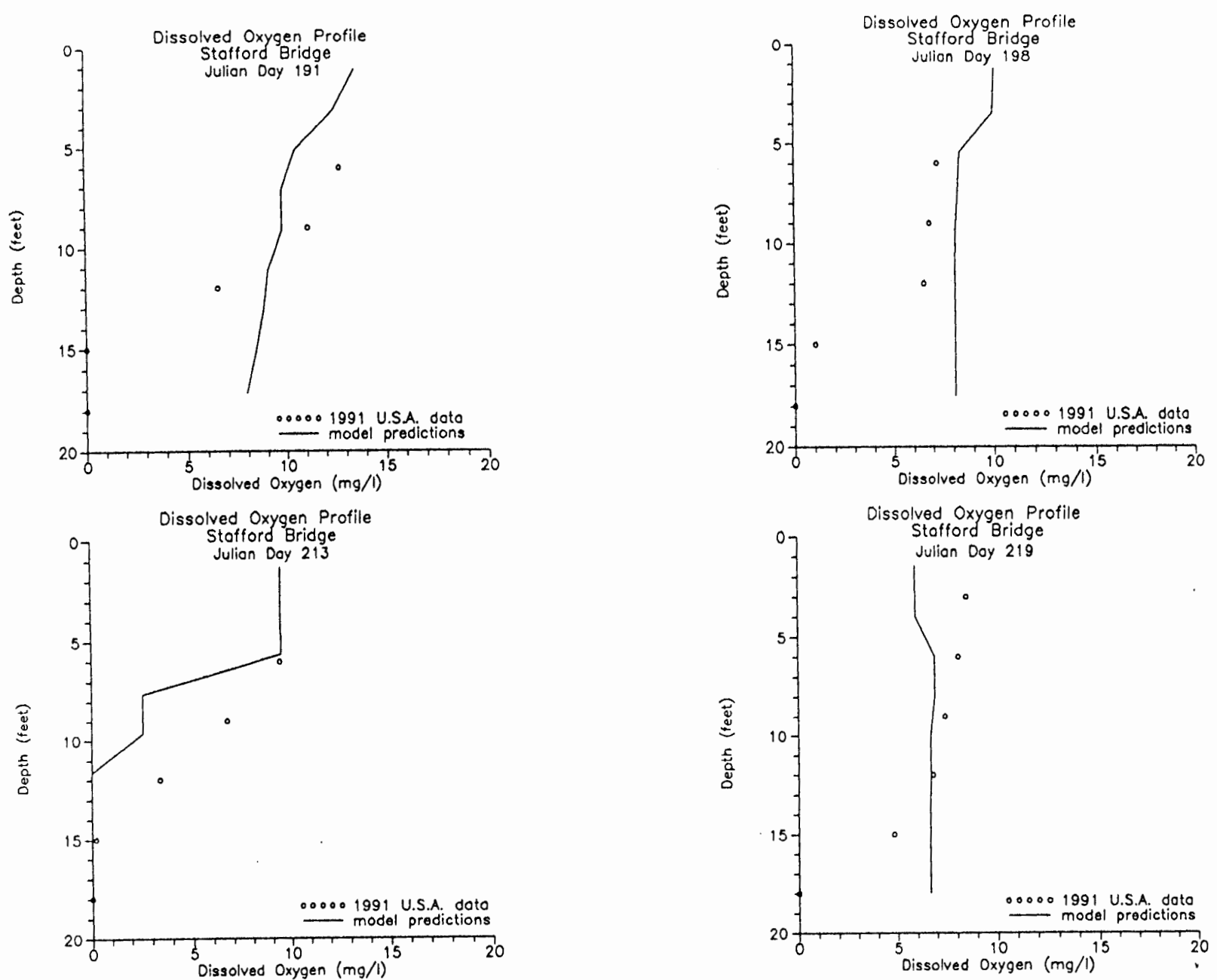

Figure 24. Calibration results for dissolved oxygen stratification at stafford Bridge. 

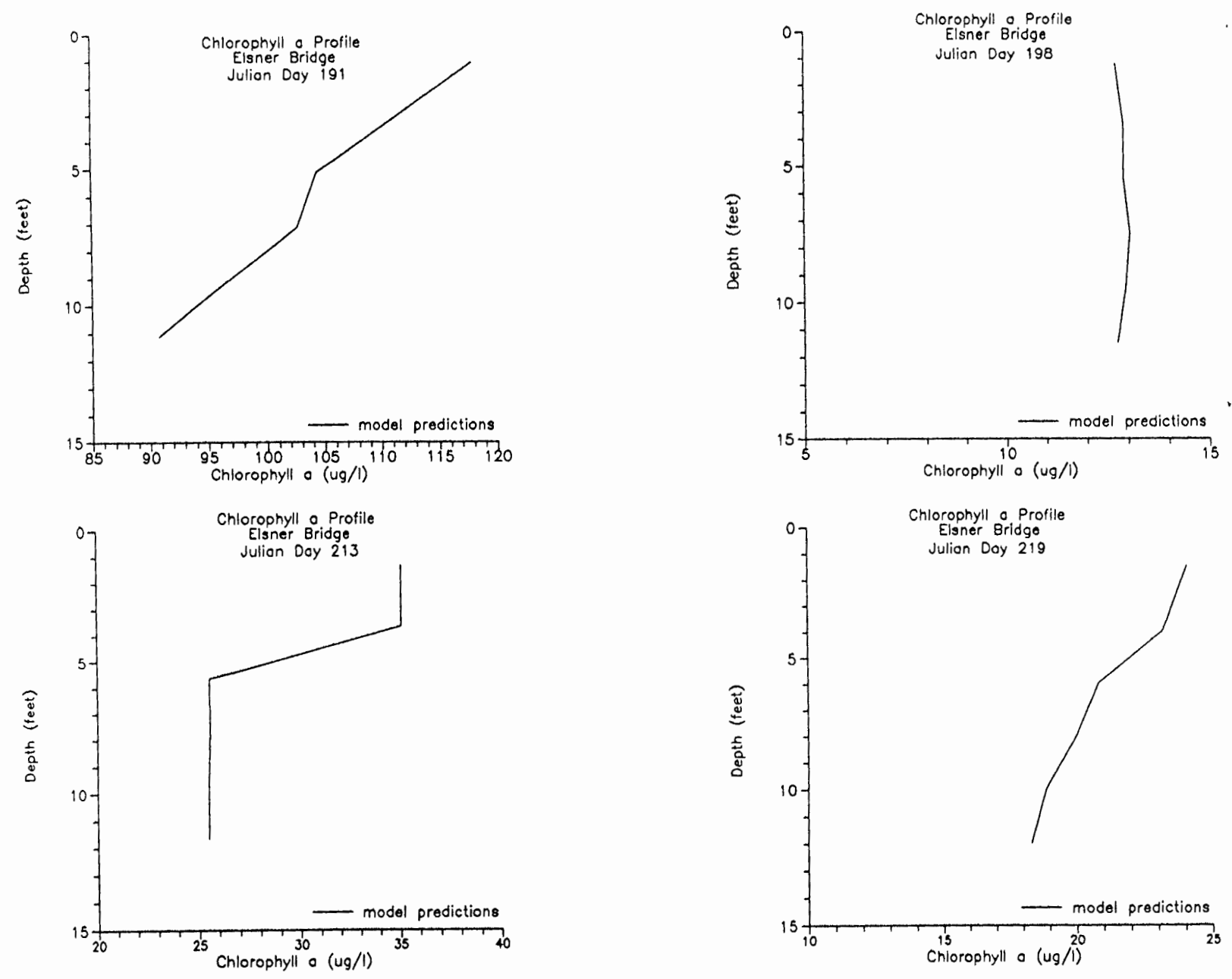

Figure 25. Model predicted chlorophyll-a stratification for the calibration run at Elsner Bridge. 

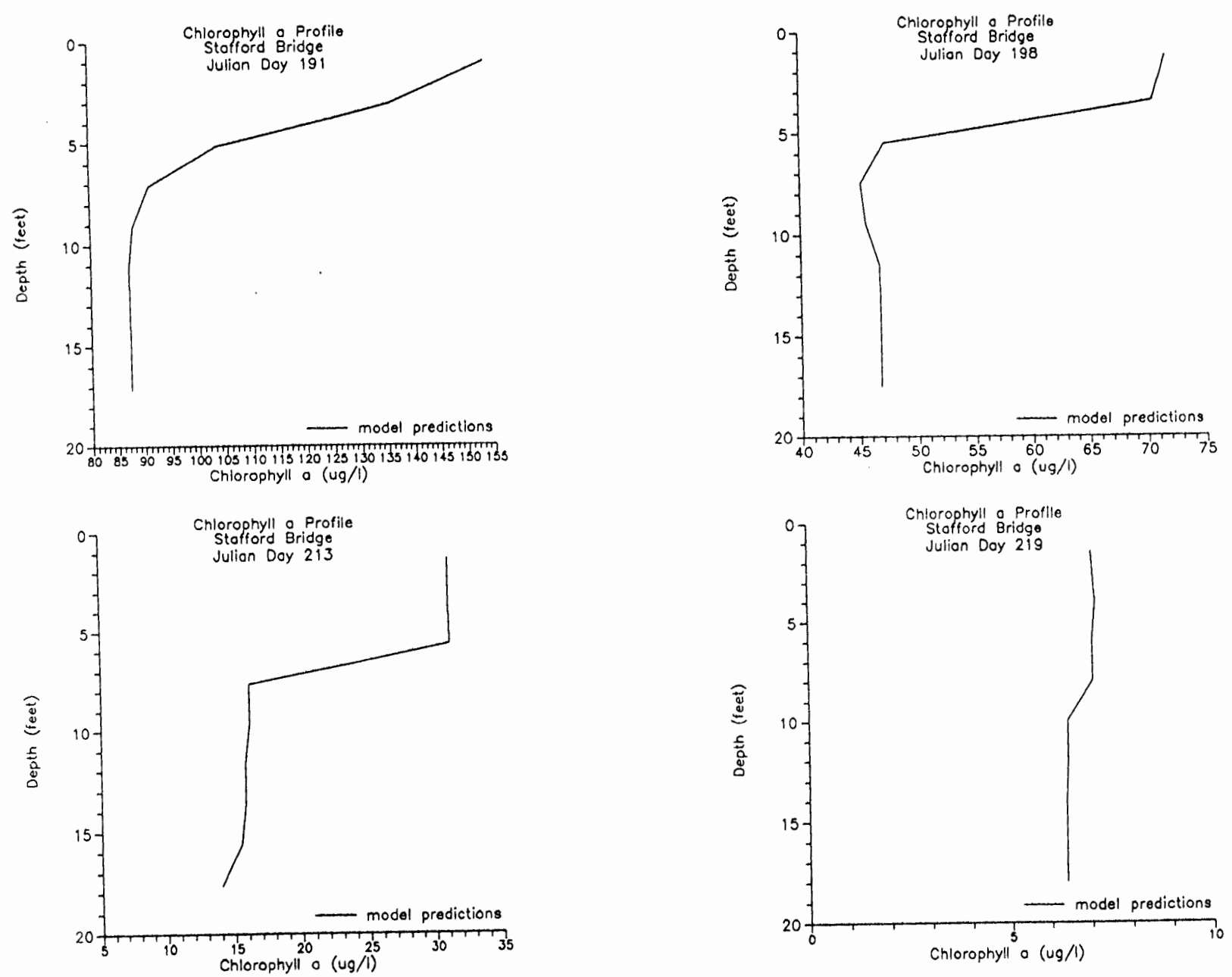

Figure 26. Model predicted chlorophyll-a stratification for the calibration run at Stafford Bridge. 
TABLE I

TUALATIN RIVER CALIBRATED COEFFICIENT VALUES

\begin{tabular}{|c|c|c|}
\hline $\begin{array}{l}\text { Coefficient } \\
\text { (Variable } \\
\text { Name in } \\
\text { Appendix } \\
\text { TABLE A-2) }\end{array}$ & $\begin{array}{l}\text { Tualatin } \\
\text { River Model } \\
\text { VALUE: }\end{array}$ & DEFINITION: \\
\hline ITEMP & 12.5 & $\begin{array}{l}\text { Initial water temperature } \\
\text { (Celsius). }\end{array}$ \\
\hline WSC & 0.80 & $\begin{array}{l}\text { Wind sheltering coef. }(1.0 \\
=\text { maximum wind, } 0.0=\text { no } \\
\text { wind) }\end{array}$ \\
\hline $\mathrm{AX}$ & 20.0 & $\begin{array}{l}\text { Horizontal dispersion coef. } \\
\text { for momentum }\left(\mathrm{m}^{2} / \mathrm{sec}\right) \text {. }\end{array}$ \\
\hline IDX & 1.0 & $\begin{array}{l}\text { Horizontal dispersion coef. } \\
\text { for heat and mass }\left(\mathrm{m}^{2} / \mathrm{sec}\right) \text {. }\end{array}$ \\
\hline AZMIN & $1.4 e-8$ & $\begin{array}{l}\text { Minimum Horizontal } \\
\text { Dispersion coef. for } \\
\text { momentum }\left(\mathrm{m}^{2} / \mathrm{sec}\right) \text {. }\end{array}$ \\
\hline DZMIN & $1.4 e-7$ & $\begin{array}{l}\text { Minimum vertical diffusion } \\
\text { coef. for heat and mass } \\
\left(\mathrm{m}^{2} / \mathrm{sec}\right) \text {. }\end{array}$ \\
\hline DZMAX & 1.0 & $\begin{array}{l}\text { Maximum vertical diffusion } \\
\text { coef. for heat and mass } \\
\left(\mathrm{m}^{2} / \mathrm{sec}\right) \text {. }\end{array}$ \\
\hline EXH2O & 1.00 & $\begin{array}{l}\text { Light extinction coef. for } \\
\text { water }\left(\mathrm{m}^{-1}\right) \text {. }\end{array}$ \\
\hline EXINOR & 0.01 & $\begin{array}{l}\text { Light extinction coef. for } \\
\text { inorganic particles } \\
(\mathrm{m} / \mathrm{mg} / \mathrm{l}) \text {. }\end{array}$ \\
\hline EXORG & 0.45 & $\begin{array}{l}\text { Light extinction coef. for } \\
\text { organic particles }(\mathrm{m} / \mathrm{mg} / \mathrm{l}) \text {. }\end{array}$ \\
\hline BETA & 0.50 & $\begin{array}{l}\text { Fraction of solar radiation } \\
\text { absorbed at surface }(-) \text {. }\end{array}$ \\
\hline COLQ10 & $\begin{array}{l}\text { not } \\
\text { used }\end{array}$ & $\begin{array}{l}\text { Q10 modification for } \\
\text { coliform die off rate. }\end{array}$ \\
\hline COLDK & not used & Coliform decay rate $\left(\mathrm{d}^{-1}\right)$. \\
\hline SSETL & 0.1 & $\begin{array}{l}\text { Suspended solids settling } \\
\text { rate (m/day). }\end{array}$ \\
\hline
\end{tabular}




\begin{tabular}{|c|c|c|}
\hline $\begin{array}{l}\text { Coefficient } \\
\text { (Variable } \\
\text { Name in } \\
\text { Appendix } \\
\text { TABLE } A-2 \text { ) }\end{array}$ & $\begin{array}{l}\text { Tualatin } \\
\text { River Model } \\
\text { VALUE: }\end{array}$ & DEFINITION: \\
\hline AGROW & 3.0 & $\begin{array}{l}\text { Maximum gross } \\
\text { photosynthetic production } \\
\text { rate }\left(d^{-1}\right) .\end{array}$ \\
\hline AMORT & 0.02 & $\begin{array}{l}\text { Maximum algal mortality } \\
\text { rate }\left(d^{-1}\right) .\end{array}$ \\
\hline AEXCR & 0.04 & $\begin{array}{l}\text { Maximum excretion rate or } \\
\text { photorespiration rate } \\
1 \text { ). }\end{array}$ \\
\hline ARESP & 0.08 & $\begin{array}{l}\text { Maximum algal dark } \\
\text { respiration rate }\left(d^{-1}\right)\end{array}$ \\
\hline ASETL & 0.20 & $\begin{array}{l}\text { Phytoplankton settling rate } \\
(\mathrm{m} / \mathrm{d}) \text {. }\end{array}$ \\
\hline ASATUR & 175.0 & $\begin{array}{l}\text { Saturation light intensity } \\
\text { at the maximum } \\
\text { photosynthetic rate }\left(\mathrm{w} / \mathrm{m}^{2}\right) \text {. }\end{array}$ \\
\hline ALGDET & 0.80 & $\begin{array}{l}\text { Fraction of dead algae } \\
\text { which becomes detritus, the } \\
\text { fraction (1-ALGDET) becomes } \\
\text { BOD-L (-). }\end{array}$ \\
\hline AGT1 & 0.0 & $\begin{array}{l}\text { Lower temperature bound for } \\
\text { algal growth (C). }\end{array}$ \\
\hline AGT2 & 18.0 & $\begin{array}{l}\text { Lowest temperature at which } \\
\text { growth processes are near } \\
\text { the maximum rate (C). }\end{array}$ \\
\hline AGT3 & 23.0 & $\begin{array}{l}\text { Upper temperature at which } \\
\text { growth processes are near } \\
\text { the maximum rate (C). }\end{array}$ \\
\hline AGT4 & 30.0 & $\begin{array}{l}\text { Upper lethal temperature } \\
\text { (C). }\end{array}$ \\
\hline AGK1 & 0.1 & $\begin{array}{l}\text { Temperature rate multiplier } \\
\text { for AGT1. }\end{array}$ \\
\hline AGK2 & 0.98 & $\begin{array}{l}\text { Temperature rate multiplier } \\
\text { for AGT2. }\end{array}$ \\
\hline AGK3 & 0.98 & $\begin{array}{l}\text { Temperature rate multiplier } \\
\text { for AGT3. }\end{array}$ \\
\hline
\end{tabular}




\begin{tabular}{|c|c|c|}
\hline $\begin{array}{l}\text { Coefficient } \\
\text { (Variable } \\
\text { Name in } \\
\text { Appendix } \\
\text { TABLE } A-2 \text { ) }\end{array}$ & $\begin{array}{l}\text { Tualatin } \\
\text { River Model } \\
\text { VALUE: }\end{array}$ & DEFINITION: \\
\hline AGK4 & 0.1 & $\begin{array}{l}\text { Temperature rate multiplier } \\
\text { for AGT } 4 \text {. }\end{array}$ \\
\hline LABDK & 0.08 & $\begin{array}{l}\text { Liable DOM decay rate } \\
\text { 1). }\end{array}$ \\
\hline LRFDK & 0.01 & $\begin{array}{l}\text { Transfer rate from liable } \\
\text { to refractory DOM }\left(\mathrm{d}^{-1}\right) \text {. }\end{array}$ \\
\hline REFDK & 0.001 & $\begin{array}{l}\text { Refractory DOM decay rate } \\
\left(d^{-1}\right) .\end{array}$ \\
\hline DETDK & 0.005 & Detritus decay rate $\left(\mathrm{d}^{-1}\right)$. \\
\hline DSETL & 0.50 & $\begin{array}{l}\text { Detrital settling velocity } \\
(\mathrm{m} / \mathrm{d}) \text {. }\end{array}$ \\
\hline OMT1 & 4.0 & $\begin{array}{l}\text { Lower temperature bound for } \\
\text { organic decomposition }(C) \text {. }\end{array}$ \\
\hline OMT2 & 20.0 & $\begin{array}{l}\text { Temperature where organic } \\
\text { decomposition is near } \\
\text { maximum (C). }\end{array}$ \\
\hline OMK1 & 0.1 & $\begin{array}{l}\text { Temperature rate multiplier } \\
\text { for OMT1. }\end{array}$ \\
\hline OMK2 & 0.98 & $\begin{array}{l}\text { Temperature rate multiplier } \\
\text { for OMT2. }\end{array}$ \\
\hline SEDDK & 0.06 & $\begin{array}{l}\text { Sediment decomposition rate } \\
\left(d^{-1}\right) \text {. }\end{array}$ \\
\hline SOD & $0.50-3.00$ & $\begin{array}{l}\text { Maximum rate of sediment } \\
\text { oxygen demand }\left(\mathrm{g} / \mathrm{m}^{2} / \text { day }\right)\end{array}$ \\
\hline KBOD & $\begin{array}{r}\text { not } \\
\text { used }\end{array}$ & Decay rate for $\operatorname{CBOD}\left(\mathrm{d}^{-1}\right)$ \\
\hline TBOD & $\begin{array}{r}\text { not } \\
\text { used }\end{array}$ & $\begin{array}{l}\text { Temperature coef. for CBOD } \\
\text { decay rate correction. }\end{array}$ \\
\hline RBOD & $\begin{array}{r}\text { not } \\
\text { used }\end{array}$ & $\begin{array}{l}\text { Decay rate for } 02 \\
\text { consumption of } C B O D\left(d^{-1}\right) \text {. }\end{array}$ \\
\hline PO4REL & 0.015 & $\begin{array}{l}\text { Rate as fraction of SOD } \\
\text { which } \mathrm{PO}_{4} \text { is released from } \\
\text { sediments during anaerobic } \\
\text { conditions }\left(\mathrm{g} / \mathrm{m}^{2} / \text { day }\right) \text {. }\end{array}$ \\
\hline
\end{tabular}




\begin{tabular}{|c|c|c|}
\hline $\begin{array}{l}\text { Coefficient } \\
\text { (Variable } \\
\text { Name in } \\
\text { Appendix } \\
\text { TABLE } A-2 \text { ) }\end{array}$ & $\begin{array}{l}\text { Tualatin } \\
\text { River Model } \\
\text { VALUE: }\end{array}$ & DEFINITION: \\
\hline PARTP & 0.100 & $\begin{array}{l}\text { Maximum amount of } \mathrm{PO}_{4} \\
\text { absorbed per gram of solids } \\
\left(\mathrm{g} \mathrm{P} \mathrm{m} / \mathrm{g} \text { solid } \mathrm{m}^{3}\right) \text {. }\end{array}$ \\
\hline AHSP & 0.005 & $\begin{array}{l}\text { Adsorption coef. of } \mathrm{PO}_{4} \text { for } \\
\text { use in the langmuir } \\
\text { isotherm }\left(\mathrm{m}^{3} / \mathrm{g}\right) \text {. }\end{array}$ \\
\hline NH3REL & 0.08 & $\begin{array}{l}\text { Rate as fraction of SOD } \\
\text { which } \mathrm{NH}_{4} \text { is released from } \\
\text { sediments during anaerobic } \\
\text { conditions }\left(\mathrm{g} / \mathrm{m}^{2} / \mathrm{day}\right) \text {. }\end{array}$ \\
\hline NH3DK & 0.65 & Ammonia decay rate $\left(\mathrm{d}^{-1}\right)$. \\
\hline PARTN & 0.001 & $\begin{array}{l}\text { Maximum amount of } \mathrm{NH}_{3} \\
\text { absorbed per gram of solids } \\
\left(9 \mathrm{~N} \mathrm{~m} / g \text { solid } \mathrm{m}^{3}\right) \text {. }\end{array}$ \\
\hline AHSN & 0.014 & $\begin{array}{l}\text { Adsorption coef. of } \mathrm{N} \text { for } \\
\text { use in the Langmuir } \\
\text { isotherm }\left(\mathrm{m}^{3} / \mathrm{g}\right) \text {. }\end{array}$ \\
\hline NH3DT1 & 5.0 & $\begin{array}{l}\text { Lower temp. bound at which } \\
\text { ammonia nitrification } \\
\text { continues (C). }\end{array}$ \\
\hline NH3DT2 & 20.0 & $\begin{array}{l}\text { Lowest temp. at which } \\
\text { nitrification is occurring } \\
\text { near the maximum rate (C). }\end{array}$ \\
\hline NH3K1 & 0.1 & $\begin{array}{l}\text { Temperature rate multiplier } \\
\text { for NH3DT1. }\end{array}$ \\
\hline $\mathrm{NH} 3 \mathrm{~K} 2$ & 0.98 & $\begin{array}{l}\text { Temperature rate multiplier } \\
\text { for NH3DT2. }\end{array}$ \\
\hline NO3DK & 0.12 & $\begin{array}{l}\text { Denitrification rate of the } \\
\text { nitrite plus nitrate- } \\
\text { nitrogen compartment - } \\
\text { anaerobic only }\left(d^{-1}\right) \text {. }\end{array}$ \\
\hline NO3DT1 & 5.0 & $\begin{array}{l}\text { Lower temp. bound at which } \\
\text { denitrification continues } \\
\text { (C). }\end{array}$ \\
\hline NO3DT2 & 20.0 & $\begin{array}{l}\text { Lowest temp. at which } \\
\text { denitrification occurs near } \\
\text { maximum rate (C). }\end{array}$ \\
\hline
\end{tabular}




\begin{tabular}{|c|c|c|}
\hline $\begin{array}{l}\text { Coefficient } \\
\text { (Variable } \\
\text { Name in } \\
\text { Appendix } \\
\text { TABLE } A-2 \text { ) }\end{array}$ & $\begin{array}{l}\text { Tualatin } \\
\text { River Model } \\
\text { VALUE: }\end{array}$ & DEFINITION: \\
\hline NO3K1 & 0.1 & $\begin{array}{l}\text { Temperature rate multiplier } \\
\text { for NO3DT } 1 \text {. }\end{array}$ \\
\hline NO3K2 & 0.98 & $\begin{array}{l}\text { Temperature rate multiplier } \\
\text { for NO3DT2. }\end{array}$ \\
\hline CO2REL & 0.10 & $\begin{array}{l}\text { Fraction relating SOD to } \\
\text { inorganic carbon production } \\
(-) \text {. }\end{array}$ \\
\hline FEREL & $\begin{array}{l}\text { not } \\
\text { used }\end{array}$ & $\begin{array}{l}\text { Rate as a fraction of SOD } \\
\text { which Fe is released from } \\
\text { sediments }\left(\mathrm{g} / \mathrm{m}^{2} / \text { day }\right) \text {. }\end{array}$ \\
\hline FESETL & $\begin{array}{r}\text { not } \\
\text { used }\end{array}$ & $\begin{array}{l}\text { Rate at which particulate } \\
\text { Fe settles (m/day). }\end{array}$ \\
\hline ZMAX & 0.85 & $\begin{array}{l}\text { Maximum ingestion rate for } \\
\text { zooplankton }\left(\mathrm{hr}^{-1}\right) \text {. }\end{array}$ \\
\hline ZMORT & 0.001 & $\begin{array}{l}\text { Zooplankton mortality rate } \\
\left(\mathrm{hr}^{-1}\right) \text {. }\end{array}$ \\
\hline ZEFFIC & 0.70 & $\begin{array}{l}\text { Zooplankton ingestion } \\
\text { efficiency }(-) \text {. }\end{array}$ \\
\hline PREF1 & 0.50 & $\begin{array}{l}\text { Preference factor of } \\
\text { zooplankton for algae (-). }\end{array}$ \\
\hline PREF2 & 0.50 & $\begin{array}{l}\text { Preference factor of } \\
\text { zooplankton for detritus } \\
\text { ). }\end{array}$ \\
\hline ZRESP & 0.10 & $\begin{array}{l}\text { Zooplankton respiration } \\
\text { rate }\left(\mathrm{hr}^{-1}\right) \text {. }\end{array}$ \\
\hline ZOOMIN & 0.001 & $\begin{array}{l}\text { Low threshold concentration } \\
\text { for zooplankton feeding } \\
\left(\mathrm{g} / \mathrm{m}^{3}\right) \text {. }\end{array}$ \\
\hline $\mathrm{ZS} 2 \mathrm{P}$ & 0.30 & $\begin{array}{l}\text { Half-saturation coef. for } \\
\text { zooplankton ingestion } \\
\left(\mathrm{g} / \mathrm{m}^{3}\right) \text {. }\end{array}$ \\
\hline ZOOT1 & 10.0 & $\begin{array}{l}\text { Lower temperature bound for } \\
\text { zooplankton growth } \\
\text { (C). }\end{array}$ \\
\hline
\end{tabular}




\begin{tabular}{|c|c|c|}
\hline $\begin{array}{l}\text { Coefficient } \\
\text { (Variable } \\
\text { Name in } \\
\text { Appendix } \\
\text { TABLE } A-2 \text { ) }\end{array}$ & $\begin{array}{l}\text { Tualatin } \\
\text { River Model } \\
\text { VALUE: }\end{array}$ & DEFINITION: \\
\hline zoOT2 & 19.0 & $\begin{array}{l}\text { Lowest temperature at which } \\
\text { growth processes are near } \\
\text { maximum (C). }\end{array}$ \\
\hline zooT3 & 23.0 & $\begin{array}{l}\text { Upper temperature at which } \\
\text { growth processes are near } \\
\text { maximum (C). }\end{array}$ \\
\hline ZOOT4 & 36.0 & $\begin{array}{l}\text { Upper lethal temperature } \\
\text { for zooplankton (C). }\end{array}$ \\
\hline ZOOK1 & 0.1 & $\begin{array}{l}\text { Temperature rate multiplier } \\
\text { for ZOOT1. }\end{array}$ \\
\hline ZOOK2 & 0.98 & $\begin{array}{l}\text { Temperature rate multiplier } \\
\text { for zOOT2. }\end{array}$ \\
\hline ZOOK3 & 0.98 & $\begin{array}{l}\text { Temperature rate multiplier } \\
\text { for ZooT3. }\end{array}$ \\
\hline ZOOK4 & 0.1 & $\begin{array}{l}\text { Temperature rate multiplier } \\
\text { for ZOOT } 4 \text {. }\end{array}$ \\
\hline O2NH3 & 4.57 & $\begin{array}{l}\text { Number of grams } \mathrm{O}_{2} \text { reqd. to } \\
\text { oxidize } 1 \mathrm{~g} \text { of } \mathrm{NH}_{4} \text { to } \mathrm{NO}_{3} \text {. }\end{array}$ \\
\hline O2ORG & 1.4 & $\begin{array}{l}\text { Stoichiometric requirement } \\
\text { for } \mathrm{O}_{2} \text { to decompose } \\
\text { organics }(-) \text {. }\end{array}$ \\
\hline O2RESP & 0.6 & $\begin{array}{l}\mathrm{O}_{2} \text { requirement for } \\
\text { biological respiration }(-) \text {. }\end{array}$ \\
\hline O2ALG & 2.0 & $\begin{array}{l}\text { Stoichiometric equivalent } \\
\text { for } \mathrm{O}_{2} \text { production during } \\
\text { photosynthesis (-). }\end{array}$ \\
\hline BIOP & 0.015 & $\begin{array}{l}\text { Stoichiometric equivalent } \\
\text { between organic matter and } \\
\text { orthophosphate }(-)\end{array}$ \\
\hline BION & 0.10 & $\begin{array}{l}\text { Stoichiometric equivalent } \\
\text { between organic matter and } \\
\text { nitrogen }(-)\end{array}$ \\
\hline BIOC & 0.45 & $\begin{array}{l}\text { Stoichiometric equivalent } \\
\text { between organic matter and } \\
\text { carbon }(-) \text {. }\end{array}$ \\
\hline
\end{tabular}




\begin{tabular}{||l|l|l|}
\hline $\begin{array}{l}\text { Coefficient } \\
\text { Variable } \\
\text { Name in } \\
\text { Appendix } \\
\text { TABLE A-2) }\end{array}$ & $\begin{array}{l}\text { Tualatin } \\
\text { River Model } \\
\text { vALUE: }\end{array}$ & DEFINITION: \\
\hline \hline O2LIM & 0.50 & $\begin{array}{l}\text { Dissolved O concentration } \\
\text { which triggers anaerobic } \\
\text { conditions (mg/l). }\end{array}$ \\
\hline
\end{tabular}


MODEL VERIFICATION

The period of verification was June through August 1990. As discussed earlier, the summer of 1990 was selected for verification rather than calibration because vertical profiles and chemical oxygen demand data were available for 1991, making it better suited as the calibration period. Figures 27 through 32 show the verification results. All constituent parameter values which had been calibrated in 1991 remained the same for the 1990 verification period. However, because of variations in the way the diversion dam flaps were raised from year to year, the input file containing the time series of dam widths was edited to correspond to 1990. Information about when the flaps were raised in 1990 was obtained from the USGS and Watermasters office. Unfortunately, this information was incomplete because on at least one occasion during that summer some of the boards were knocked down by vandals. The number of flaps raised had to be inferred from water level data measured by the gaging station on the Tualatin River at the Lake Oswego Canal.

The distributed tributary input to the Tualatin used in 1991, which totaled 70 cfs and functioned through Julian day 200, was not used for the verification. Model inflows from the upstream boundary, Fanno creek and the Durham Treatment Plant were sufficient to adequately predict model outflow. Constituent inflow files were created using 1990 
sampling data. Data for a few of the constituents were unavailable and these inflow concentrations had to be assumed. Unlike in 1991, chemical oxygen demand data for Fanno Creek and the upstream boundary were not available in 1990. Labile BOD, refractory BOD, and detritus concentrations were given values of $1.00 \mathrm{mg} / 1,0.10 \mathrm{mg} / 1$, and $0.10 \mathrm{mgl}$, respectively. These concentrations were estimated through the inspection of the 1991 chemical oxygen demand data and were thought to be typical.

Zooplankton inflow concentrations were estimated by inferring their grazing effect on algal concentrations. As had been done for the calibration period, the concentrations were kept small enough so as to minimize their effect in the upper pool region near Elsner, but the calibrated growth rate was large enough so that zooplankton grazing would reduce algae concentrations by the time they reached the lower pool (Figure 32). 

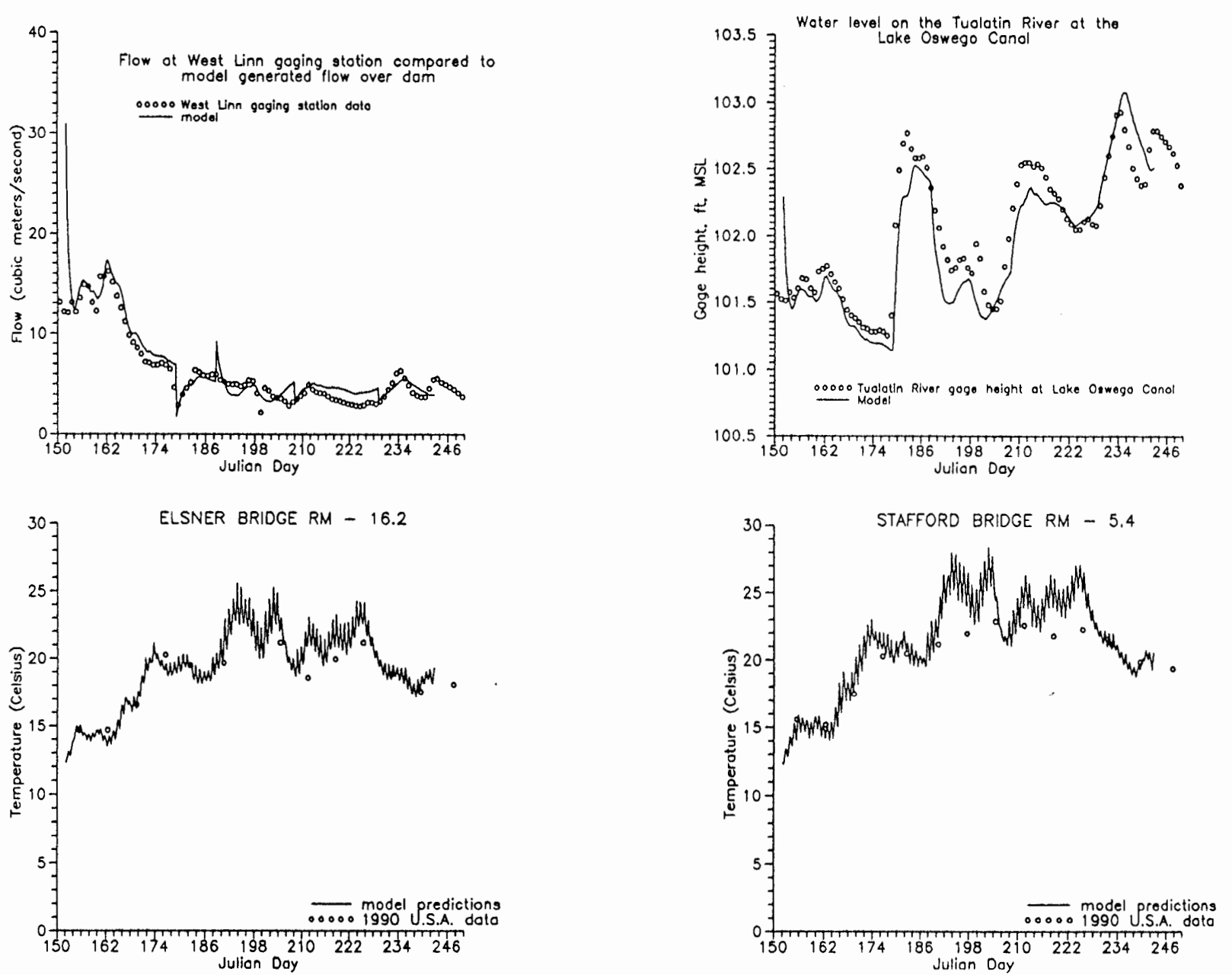

Figure 27. Verification results for flow, water surface elevation, and temperature. 

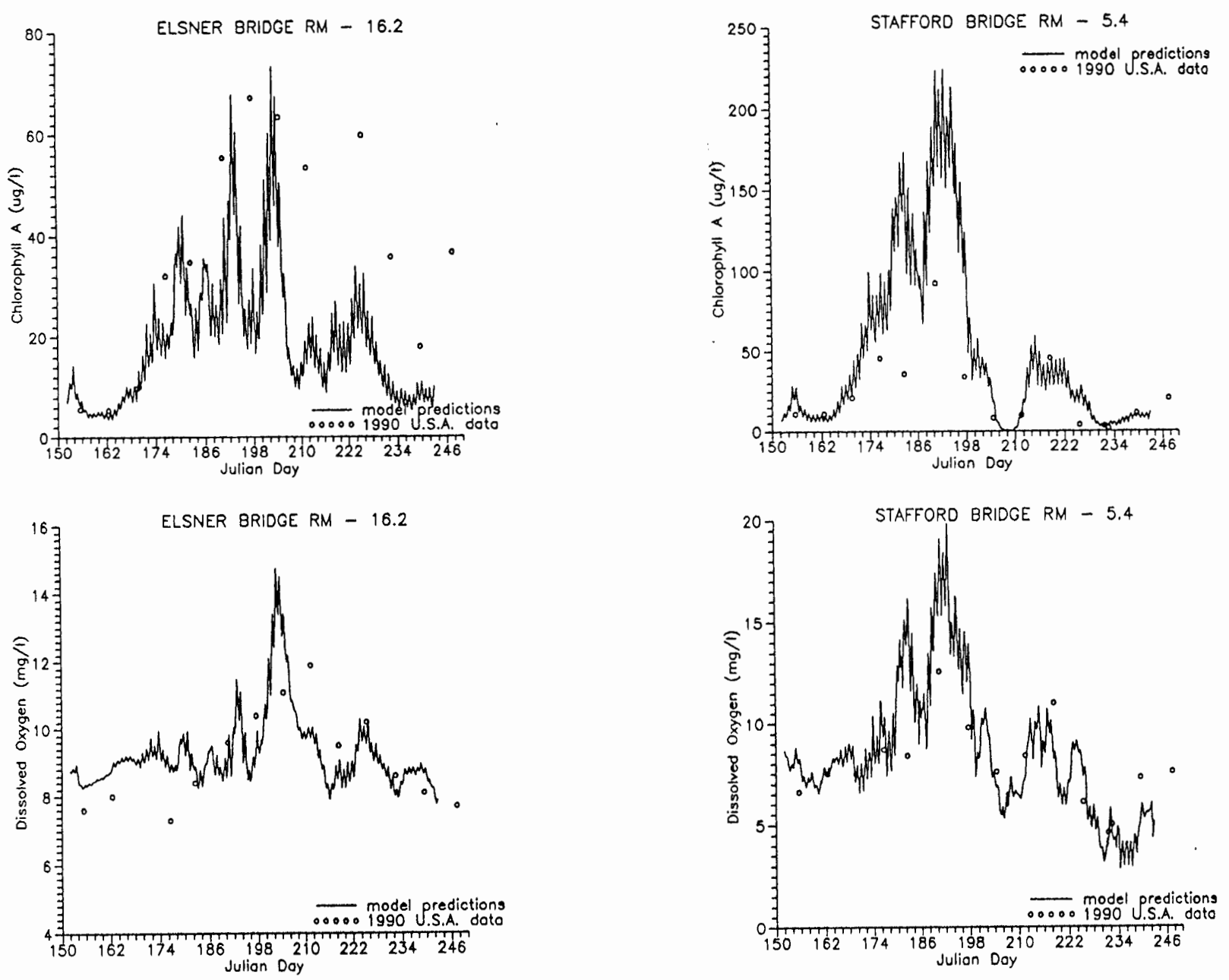

Figure 28. Verification results for chlorophyll-a and dissolved oxygen. 

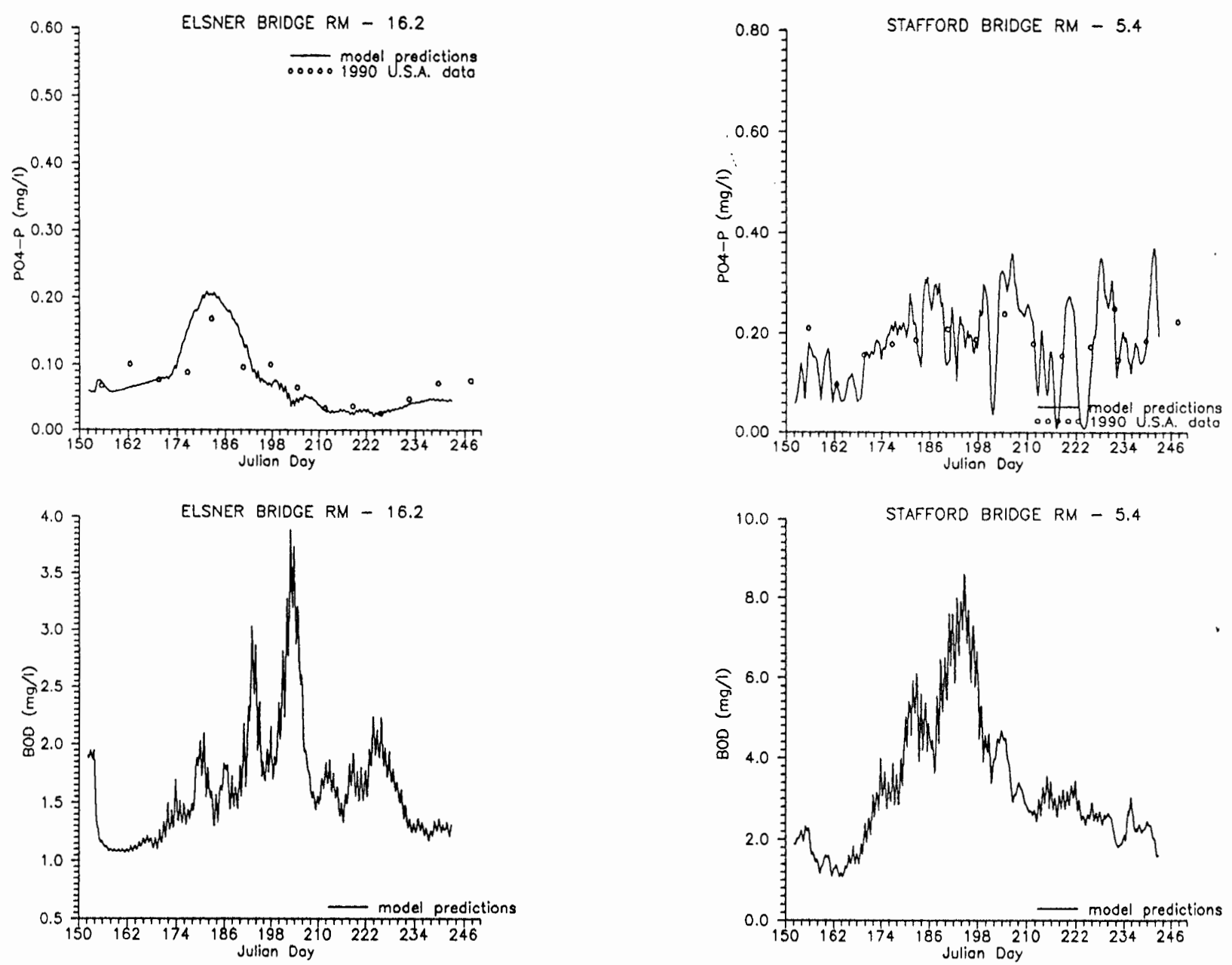

Figure 29. Verification results for orthophosphorus and biochemical oxygen demand. 

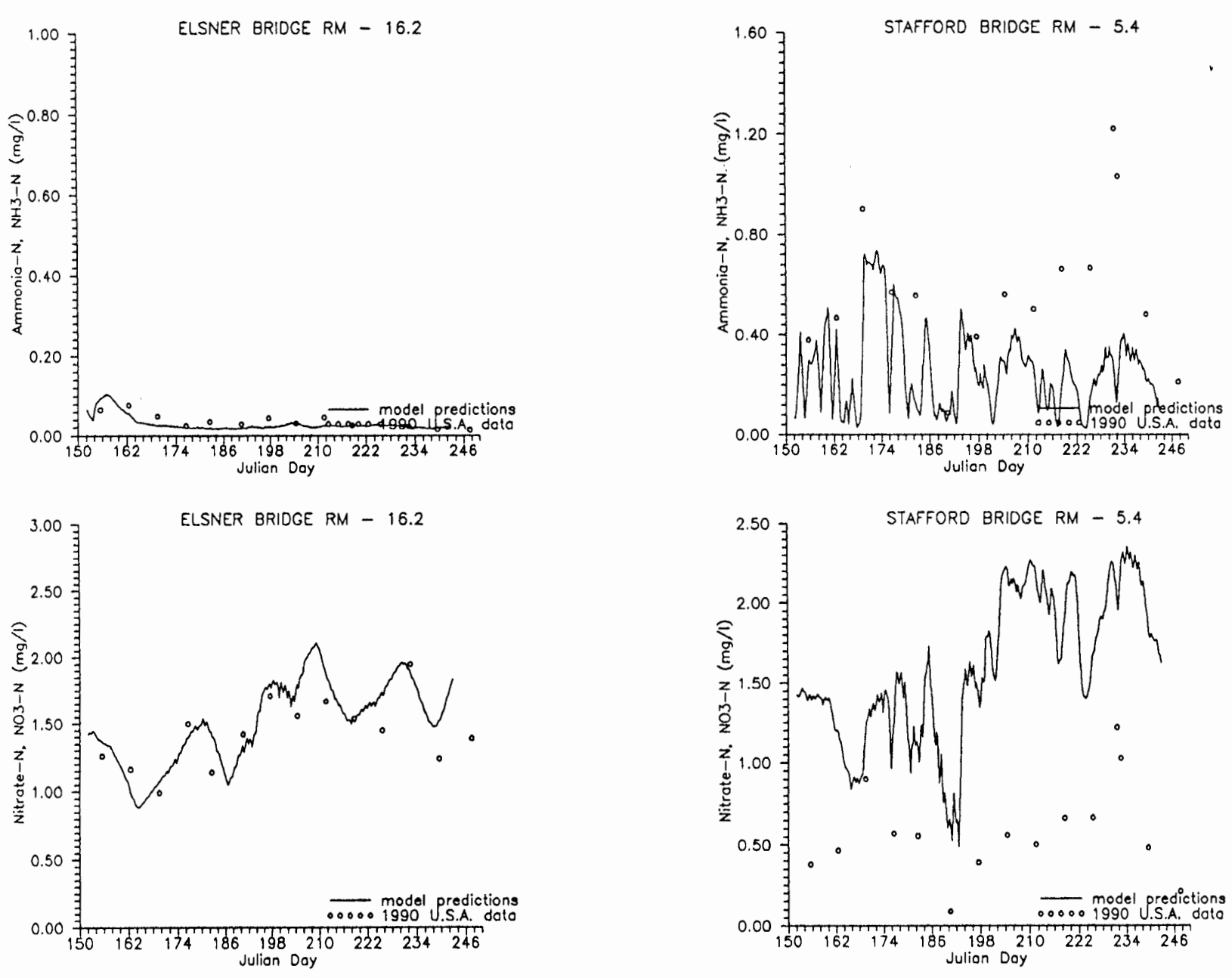

Figure 30. Verification results for ammonia nitrogen and nitrite/nitrate nitrogen. 

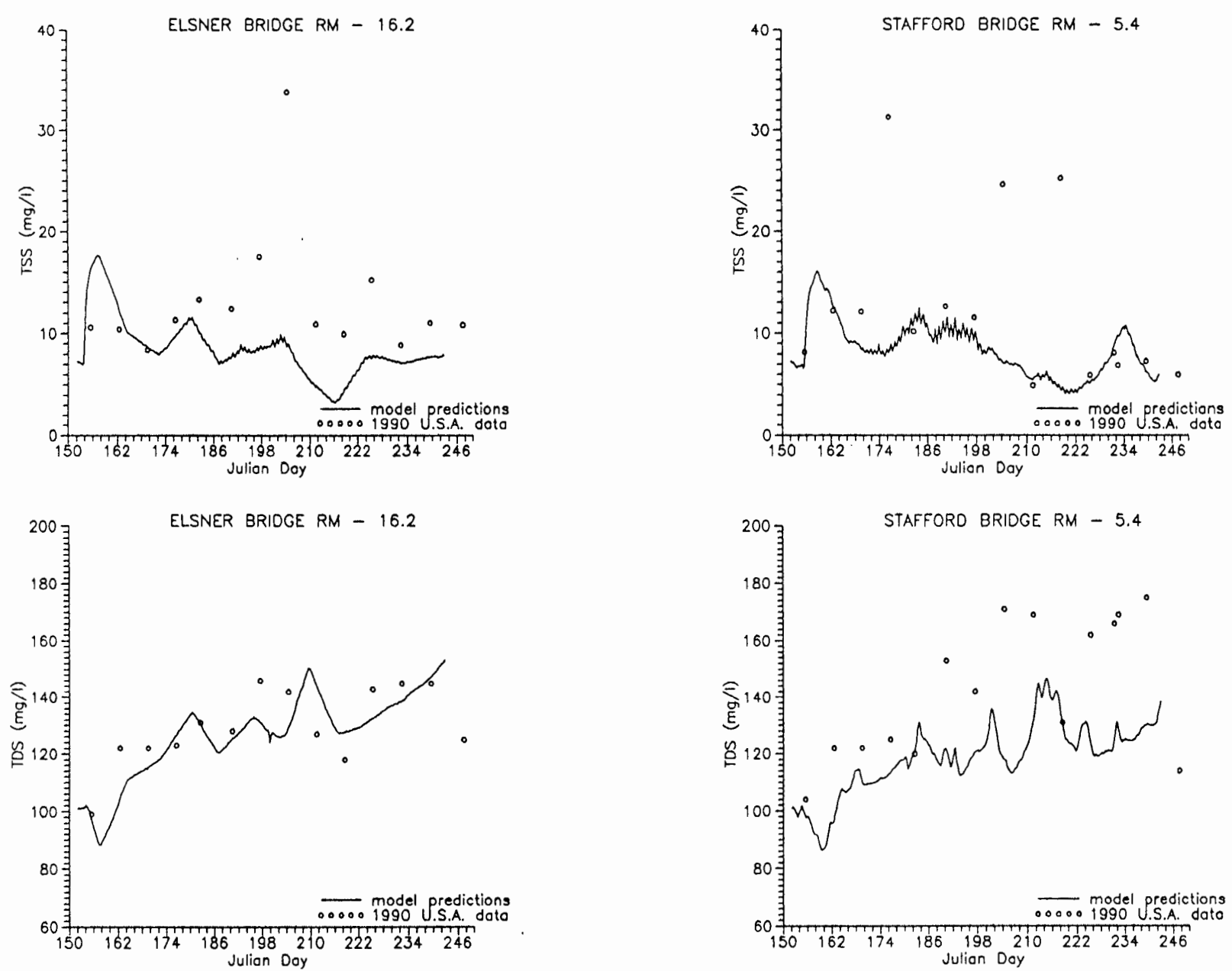

Figure 31. Verification results for total suspended solids and total dissolved solids. 

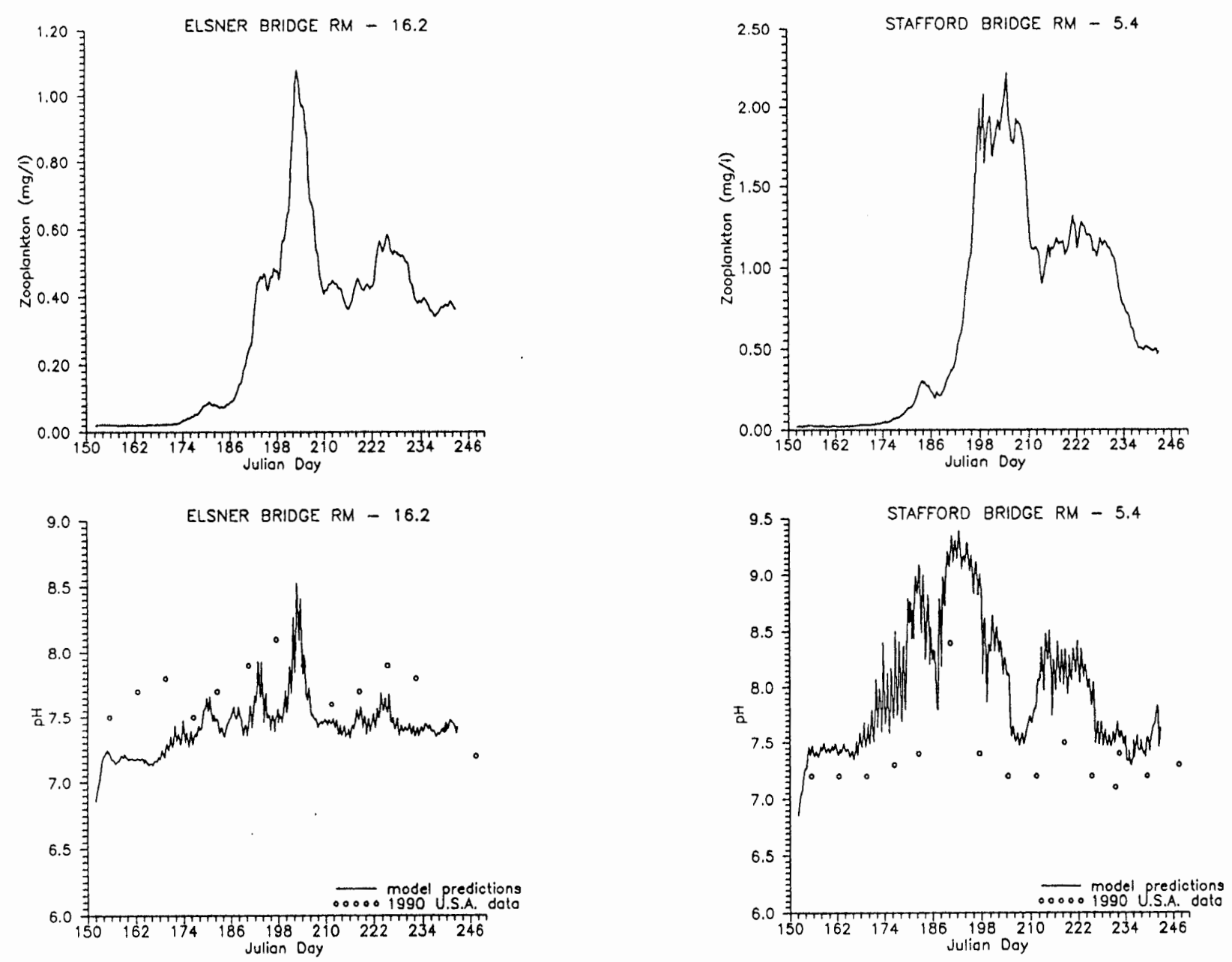

Figure 32. Verification results for $\mathrm{pH}$ and model predicted zooplankton. 


\section{CHAPTER V}

\section{MANAGEMENT ALTERNATIVES}

\section{INTRODUCTION}

Following model calibration and verification, modifications were made to the model corresponding to different pollution control alternatives. The management alternatives evaluated were flow augmentation, Lake Oswego diversion dam removal, tributary phosphorus load reduction, leaving the diversion dam flash boards down, and combinations of these alternatives. Scenario results were compared using statistical criteria describing temperature, $\mathrm{pH}$, and constituent concentrations. of special interest were the number of water quality violations caused by each alternative. Water quality goals were violated if at any time or location $\mathrm{pH}$ exceeded 8.5, the dissolved oxygen concentration fell below $6.0 \mathrm{mg} / 1$, or the chlorophyll-a concentration exceeded $15.0 \mu \mathrm{g} / \mathrm{l}$. To facilitate evaluation of scenario results, temporal and spatially averaged statistics were developed to quantify the severity and distribution of the violations.

The goal behind the formulation of each alternative was the improvement of water quality and aesthetic conditions in the river. The alternatives are listed in Table II. 
TABLE II

POLLUTION CONTROL ALTERNATIVES

\begin{tabular}{|c|l||}
\hline Alternative & Description \\
\hline \hline A & Base Case \\
\hline B & Flow augmentation of $100 \mathrm{cfs}$ \\
\hline C & Flow augmentation of $200 \mathrm{cfs}$ \\
\hline D & Diversion dam flash boards down \\
\hline E & $\begin{array}{l}\text { Diversion dam flash boards down and 100 cfs } \\
\text { flow augmentation }\end{array}$ \\
\hline F & $\begin{array}{l}\text { Tributary and upstream phosphorus load } \\
\text { reduction of } 50 \%\end{array}$ \\
\hline G & Removal of Diversion Dam \\
\hline
\end{tabular}

\section{BASE CASE AND ALTERNATIVE DESCRIPTIONS}

\section{Base Case}

The base case embodies present river water quality and hydrodynamic conditions and creates a benchmark from which management alternatives could be measured. The calibration period of June through August of 1991 was used for the base case. All management alternatives are identical to the base case except for the attributes distinguishing a particular scenario. 
Flow Augmentation: $100 \mathrm{cfs}$ and $200 \mathrm{cfs}$

Low summer flows are one of the contributing factors to poor water quality conditions on the Tualatin River. Low flow rates produce longer detention times, giving algae moving through the system more time to grow. Increasing summer flows would limit algal growth by decreasing residence time in the river. The additional flow would be created with increased releases originating from Hagg Lake, Barney Reservoir, and/or a future unspecified source.

Two model simulations using flow augmentation rates of $100 \mathrm{cfs}$ and $200 \mathrm{cfs}$, which were approximately $50 \%$ and $100 \%$ increases above typical late summer flows, were made. The upstream boundary inflows were increased above their 1991 flows by these rates. Constituent inflow concentrations were identical to those used in the base case.

\section{Diversion Dam Flash Boards Down}

The long reservoir of water impounded behind the LOC Diversion Dam was also believed to negatively impact water quality conditions in the river. The reservoir increases the river's detention time, providing more time for heating and algal growth. The impact of the dam is further aggravated when the dam's flash boards are raised for the summer. Another management option included leaving the flash boards down for the summer.

The set-up for this alternative required modifying the model input file containing the time series of dam widths. 
Dam width was maintained at the winter time distance when all the flash boards are left down.

Flash Boards Down with $100 \mathrm{cfs}$ Flow Augmentation

Since leaving the flash boards down and utilizing flow augmentation may improve water quality, the effect of implementing both strategies was investigated. This scenario required very little additional work because the necessary input files had already been developed for the previously described alternatives. A flow augmentation rate of 100 cfs was used.

\section{Phosphorus Load Reduction of $50 \%$}

The availability of nutrients critical for algal growth is another contributing cause of poor water quality conditions. If phosphorus loading into the river were reduced, algal growth may decrease because phosphorus is thought to be the limiting nutrient for algal growth.

For this option, phosphorus loading from Fanno creek, the USA Treatment Plant at Durham, and the model's upstream boundary were reduced by $50 \%$. Since the constituent inflow files modified were created from sampling data obtained in 1991, the 50\% phosphorus reduction for the Durham wastewater treatment plant is in addition to the reduction produced by the tertiary treatment process. 
Removal of Lake Oswego Diversion Dam

Another possible management alternative is the removal of Lake Oswego Diversion Dam. Although removal would not completely eliminate the sluggish, slow moving conditions which characterize the lower river, the decrease in water level may shorten the detention times for algal growth. The river stretch which had been inundated by the diversion dam's reservoir would become two pools separated by a shallow riffle near the Durham Treatment plant outflow at river mile 9.5 .

Unlike the previous scenarios, the CE-QUAL-W2 code had to be modified to simulate the new hydrodynamic conditions introduced by this alternative. The diversion dam was built on a shallow area marking the end of the river stretch of low elevation fall. Immediately downstream of the dam location, the river begins a relatively steep descent to the willamette River. Removing the dam would produce a shallow riffle which would control water levels upstream to the shoal area at Durham or perhaps further, depending on the river's flow. Since the decrease in the bottom channel elevation would be fairly rapid beyond the former dam site, this riffle was modeled as a weir since the downstream conditions would not affect flow through this shallow area except during high flow conditions.

The "no dam" model was divided into two branches, with the separation point corresponding to the shoal area near 
Durham. Flow over the shoal area was modeled either as a weir or as an internal head boundary condition, depending on the water level conditions. If the water level in the cell below the shallow area at Durham was greater than the crest elevation of the shoal, downstream conditions were assumed to affect flow over the shoal, and flow between branches were simulated using an internal head boundary. If the water level in the cell below the shallow area was less than the crest elevation of the shoal, flow between branches was modeled with a weir algorithm. If water velocities through the riffle exceeded critical velocity, downstream conditions would no longer affect upstream flow.

\section{ALTERNATIVE EVALUATION CRITERIA}

\section{Mean and Standard Deviation}

To evaluate the effect of the different pollution control alternatives, water quality statistics which summarized a scenario's impact on water quality conditions were compiled. Mean and standard deviations of temperature, $\mathrm{pH}$, and water quality constituent concentration at two locations gave an indication to which alternative effected the greatest overall improvements in water quality. The mean and standard deviation were calculated using data representing periodic samples of constituent concentration, temperature, and pH. During a model run values were output every few hundred iterations, generally producing 10 to 20 
sample points a day. As in the calibration, stafford Bridge and Elsner Bridge were chosen as the sample locations. The mean represented the average value of the water quality variable over the model run and was defined as

$$
\bar{x}=\sum_{i=1}^{n} \frac{x_{i}}{n}
$$

where

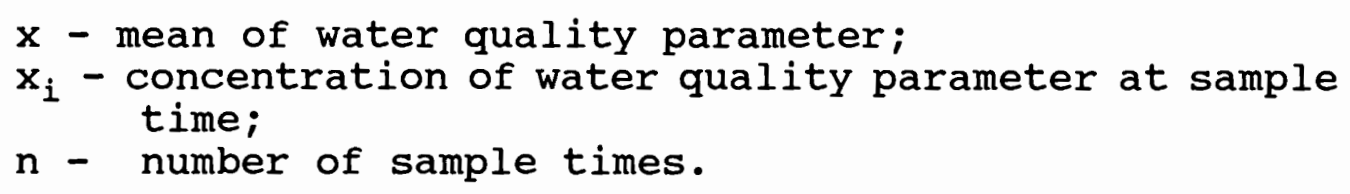
time;$$
\mathrm{n} \text { - number of sample times. }
$$

The standard deviation, defined as the average deviation from the mean over the model run was the water quality variable

$$
S=\sqrt{\frac{\sum_{i=1}^{n}\left(x_{i}-\bar{x}\right)^{2}}{(n-1)}}
$$

where

s - standard deviation.

\section{Environmental Performance criteria}

Water quality standards and goals were considered violated if at any time or location the chlorophyll-a concentration exceeded $15 \mu \mathrm{g} / \mathrm{l}$, the dissolved oxygen concentration fell below $6.0 \mathrm{mg} / \mathrm{l}$, or the $\mathrm{pH}$ was greater than 8.5 .

The environmental performance statistic represented the average number of model cells which were in violation over 
the entire model run. This performance criterion was computed by repeatedly scanning all active model cells at a specified time interval and counting those which violated a water quality standard. At the end of the model run, when all the violation counts and their associated time intervals were accumulated, the time-weighted average number of cells which were in violation was calculated. This statistic was defined by the following expression:

$$
V=\frac{\sum_{i=1}^{N_{t}}\left(\sum_{j=1}^{N_{c}} x_{j}\right) \Delta t_{i}}{T}
$$

$\mathrm{V}$ - average number of model cells violating a water quality standard or goal over a model run;

$x_{j}$ - violation counter $\left(x_{j}=1\right.$ if violation, $x_{j}=0$ otherwise);

$N_{t}$ - number of times model scanned for violations during a run;

$\mathrm{N}_{\mathrm{C}}$ - number of active cells;

$\Delta t_{i}-t i m e$ interval between model scans;

$T$ - total run time.

To show the distribution of the water quality violations, the average number of model cells which violated a water quality standard within designated intervals was calculated. This calculation was equivalent to determining the average number of cells which violated a water quality standard in equation (38), except that the violations were sorted according to the degree of the violation. If the average count from all the intervals were totaled, the number would be equivalent to equation (38). This 
relationship can be illustrated with

$$
V=V_{c_{1}, c_{2}}+V_{c_{2}, c_{3}}+\ldots+V_{c_{k-1}, c_{k}}+\ldots+V_{c_{n-1}, c_{n}}
$$

where

$$
V_{c_{k-1}, c_{k}}=\frac{\sum_{i=1}^{N_{t}}\left(\sum_{j=1}^{N_{c}} X_{j}\right) \Delta t_{i}}{T}
$$

is the average number of cell violations occurring in the interval from $c_{k-1}$ to $c_{k}$. Histograms were used to show the distribution of violations.

The mean value of the violations for a water quality variable was also computed using

$$
\bar{x}_{v}=\frac{\sum_{i=1}^{N_{t}}\left(\sum_{j=1}^{N_{v}} C_{j}\right) \Delta t_{i}}{T}
$$

$$
\begin{aligned}
& x_{v} \text { - mean value or concentration of violations; } \\
& c_{j} \text { - concentration or value of violations. }
\end{aligned}
$$

This statistic gives the location of the centroid of the violation histogram. 


\section{ALTERNATIVES EVALUATION}

Figures 33 through 39 show the environmental performance histograms for each of the management alternatives. The bar graphs shown in Figures 40,41 and 42 compare the time and spatially averaged number of chlorophyll-a, dissolved oxygen, and pH violations caused by each of the alternatives. Constituent averages and standard deviations at Elsner and stafford for the scenarios are listed in Table III. Table IV ranks the alternatives and summarizes the percent change in value of critical water parameters relative to the base case.

The management alternative that produced the greatest improvement in water quality was the 200 cfs flow augmentation option. As can be seen on the histograms and bar graphs, this alternative resulted in the largest decrease in water quality violations of all the options. When compared to the base case results, the number of dissolved oxygen, pH, and chlorophyll-a violations decreased by $21 \%, 92 \%$, and $45 \%$, respectively. The mean chlorophyll-a concentration decreased by $54 \%$ at Elsner and $32 \%$ at stafford. The option proposing a flow augmentation of 100 cfs while leaving the diversion dam's flash boards down for the summer ranked next in effectiveness. This followed by the $100 \mathrm{cfs}$ flow augmentation alternative, the 50\% reduction in phosphorus loading option, the flash boards down option and the no diversion dam option. 
The reduced phosphorus loading alternative decreased $\mathrm{pH}$ violations by $72 \%$ and chlorophyll a violations by $11 \%$. The mean chlorophyll a concentration decreased by $23 \%$ at Elsner and 17\% at stafford. When compared with the flow augmentation alternatives, the reduced phosphorus loading option was not as effective in eliminating water quality violations. Although the number of $\mathrm{pH}$ and chlorophyll a violations were lower relative to the base case, dissolved oxygen violations actually increased. The diminished phosphorus concentrations resulted in decreased algal growth, thus reducing the photosynthetic production of dissolved oxygen.

The flash boards down alternative produced the curious result of improving water quality conditions at Elsner (river mile 16.2) while slightly worsening conditions downriver at stafford (river mile 5.4). In development of this alternative it was believed that the decreased detention time resulting from smaller river volumes would be an effective restriction on algal growth. This was true for upstream regions of the pool area near Elsner but down river the drag on growth caused by the lower detention time was negated by the improved growth conditions caused warmer water temperatures. The warmer water temperatures were the result of increased shallowness and reduced river volume created by the decrease in depth, making the river more susceptible to solar heating. 
TABLE III

MODEL PREDICTED CONSTITUENT MEANS AND STANDARD DEVIATIONS AT ELSNER AND STAFFORD

\begin{tabular}{|c|c|c|c|c|c|c|c|}
\hline $\begin{array}{l}\text { Constituent } \\
\text { - Location }\end{array}$ & $\begin{array}{l}\text { Base } \\
\text { Case }\end{array}$ & $\begin{array}{l}100 \text { cfs } \\
\text { flow } \\
\text { augmen- } \\
\text { tation }\end{array}$ & $\begin{array}{l}200 \text { cfs } \\
\text { flow } \\
\text { augmen- } \\
\text { tation }\end{array}$ & $\begin{array}{l}\text { Div. Dam } \\
\text { Flash } \\
\text { Boards } \\
\text { Down }\end{array}$ & $\begin{array}{l}\text { Flash } \\
\text { Boards } \\
\text { Down }+ \\
100 \text { cfs }\end{array}$ & $\begin{array}{l}50 \% \text { PO4-P } \\
\text { reduction } \\
\text { in tribs. }\end{array}$ & $\begin{array}{l}\text { No } \\
\text { Diver- } \\
\text { sion Dam }\end{array}$ \\
\hline $\begin{array}{l}\text { Chlorophyll } \\
\text { a (ug/l) - } \\
\text { Elsner }\end{array}$ & $\begin{array}{l}31.1 \\
( \pm 23.5)\end{array}$ & $\begin{array}{l}20.1 \\
( \pm 18.3)\end{array}$ & $\begin{array}{l}14.3 \\
( \pm 12.4)\end{array}$ & $\begin{array}{l}26.6 \\
( \pm 23.7)\end{array}$ & $\begin{array}{l}16.4 \\
( \pm 15.2)\end{array}$ & $\begin{array}{l}24.1 \\
( \pm 15.5)\end{array}$ & $\begin{array}{l}18.8 \\
( \pm 17.1)\end{array}$ \\
\hline $\begin{array}{l}\text { Dissolved } \\
\text { Oxygen } \\
\text { (mg/l) - } \\
\text { Elsner }\end{array}$ & $\begin{array}{l}9.2 \\
( \pm 1.7)\end{array}$ & $\begin{array}{l}8.5 \\
( \pm 1.4)\end{array}$ & $\begin{array}{l}8.2 \\
( \pm 1.2)\end{array}$ & $\begin{array}{l}8.9 \\
( \pm 1.7)\end{array}$ & $\begin{array}{l}8.2 \\
( \pm 1.4)\end{array}$ & $\begin{array}{l}8.7 \\
( \pm 1.3)\end{array}$ & $\begin{array}{l}8.4 \\
( \pm 1.4)\end{array}$ \\
\hline pH - Elsner & $\begin{array}{l}7.4 \\
( \pm 0.2) \\
\end{array}$ & $\begin{array}{l}7.3 \\
( \pm 0.1) \\
\end{array}$ & $\begin{array}{l}7.2 \\
( \pm 0.1) \\
\end{array}$ & $\begin{array}{l}7.4 \\
( \pm 0.2) \\
\end{array}$ & $\begin{array}{l}7.3 \\
( \pm 0.1) \\
\end{array}$ & $\begin{array}{l}7.4 \\
( \pm 0.1) \\
\end{array}$ & $\begin{array}{l}7.5 \\
( \pm 0.2) \\
\end{array}$ \\
\hline $\begin{array}{l}\mathrm{pH}- \\
\text { Stafford }\end{array}$ & $\begin{array}{l}7.8 \\
( \pm 0.3) \\
\end{array}$ & $\begin{array}{l}7.7 \\
( \pm 0.3) \\
\end{array}$ & $\begin{array}{l}7.5 \\
( \pm 0.2) \\
\end{array}$ & $\begin{array}{l}7.8 \\
( \pm 0.4) \\
\end{array}$ & $\begin{array}{l}7.6 \\
( \pm 0.3) \\
\end{array}$ & $\begin{array}{l}7.7 \\
( \pm 0.3) \\
\end{array}$ & $\begin{array}{l}8.1 \\
( \pm 0.6) \\
\end{array}$ \\
\hline $\begin{array}{l}\text { Temperature } \\
{ }^{\circ} \mathrm{C}-\text { Elsner }\end{array}$ & $\begin{array}{l}18.7 \\
( \pm 2.3) \\
\end{array}$ & $\begin{array}{l}18.3 \\
( \pm 2.1)\end{array}$ & $\begin{array}{l}17.9 \\
( \pm 2.0)\end{array}$ & $\begin{array}{l}19.0 \\
( \pm 2.5)\end{array}$ & $\begin{array}{l}18.2 \\
( \pm 2.0)\end{array}$ & $\begin{array}{l}18.7 \\
( \pm 2.3)\end{array}$ & $\begin{array}{l}19.1 \\
( \pm 2.3)\end{array}$ \\
\hline
\end{tabular}




\begin{tabular}{|c|c|c|c|c|c|c|c|}
\hline $\begin{array}{l}\text { Constituent } \\
\text { - Location }\end{array}$ & $\begin{array}{l}\text { Base } \\
\text { Case }\end{array}$ & $\begin{array}{l}100 \text { cfs } \\
\text { flow } \\
\text { augmen- } \\
\text { tation }\end{array}$ & $\begin{array}{l}200 \text { cfs } \\
\text { flow } \\
\text { augmen- } \\
\text { tation }\end{array}$ & $\begin{array}{l}\text { Div. Dam } \\
\text { Flash } \\
\text { Boards } \\
\text { Down }\end{array}$ & $\begin{array}{l}\text { Flash } \\
\text { Boards } \\
\text { Down }+ \\
100 \text { cfs }\end{array}$ & $\begin{array}{l}50 \% \text { PO4-P } \\
\text { reduction } \\
\text { in tribs. }\end{array}$ & $\begin{array}{l}\text { No } \\
\text { Diver- } \\
\text { sion Dam }\end{array}$ \\
\hline $\begin{array}{l}\text { Temperature } \\
{ }^{\circ} \mathrm{C}- \\
\text { Stafford }\end{array}$ & $\begin{array}{l}19.8 \\
( \pm 2.6)\end{array}$ & $\begin{array}{l}19.4 \\
( \pm 2.4)\end{array}$ & $\begin{array}{l}19.0 \\
( \pm 2.3)\end{array}$ & $\begin{array}{l}20.1 \\
( \pm 2.9)\end{array}$ & $\begin{array}{l}19.3 \\
( \pm 2.4)\end{array}$ & $\begin{array}{l}19.8 \\
( \pm 2.6)\end{array}$ & $\begin{array}{l}21.0 \\
( \pm 2.6)\end{array}$ \\
\hline $\begin{array}{l}\mathrm{PO4-P} \\
(\mathrm{mg} / \mathrm{l})- \\
\text { Elsner }\end{array}$ & $\begin{array}{l}0.037 \\
( \pm 0.011)\end{array}$ & $\begin{array}{l}0.044 \\
( \pm 0.008)\end{array}$ & $\begin{array}{l}0.047 \\
( \pm 0.007)\end{array}$ & $\begin{array}{l}0.041 \\
( \pm 0.011)\end{array}$ & $\begin{array}{l}0.046 \\
( \pm 0.007)\end{array}$ & $\begin{array}{l}0.02 \\
( \pm 0.01)\end{array}$ & $\begin{array}{l}0.048 \\
( \pm 0.007)\end{array}$ \\
\hline $\begin{array}{l}\text { Po4-P } \\
\text { (mg/l) - } \\
\text { Stafford }\end{array}$ & $\begin{array}{l}0.089 \\
( \pm 0.035)\end{array}$ & $\begin{array}{l}0.08 \\
( \pm 0.024)\end{array}$ & $\begin{array}{l}0.078 \\
( \pm 0.018)\end{array}$ & $\begin{array}{l}0.095 \\
( \pm 0.038)\end{array}$ & $\begin{array}{l}0.085 \\
( \pm 0.026)\end{array}$ & $\begin{array}{l}0.045 \\
( \pm 0.019)\end{array}$ & $\begin{array}{l}0.246 \\
( \pm 0.101)\end{array}$ \\
\hline $\begin{array}{l}\mathrm{NH} 4-\mathrm{N} \\
(\mathrm{mg} / \mathrm{l})- \\
\text { Elsner }\end{array}$ & $\begin{array}{l}0.022 \\
( \pm 0.006)\end{array}$ & $\begin{array}{l}0.02 \\
( \pm 0.005)\end{array}$ & $\begin{array}{l}0.021 \\
( \pm 0.006)\end{array}$ & $\begin{array}{l}0.02 \\
( \pm 0.006)\end{array}$ & $\begin{array}{l}0.02 \\
( \pm 0.005)\end{array}$ & $\begin{array}{l}0.021 \\
( \pm 0.006)\end{array}$ & $\begin{array}{l}0.02 \\
( \pm 0.006)\end{array}$ \\
\hline $\begin{array}{l}\mathrm{NH} 4-\mathrm{N} \\
(\mathrm{mg} / \mathrm{l})- \\
\text { Stafford }\end{array}$ & $\begin{array}{l}0.315 \\
( \pm 0.177)\end{array}$ & $\begin{array}{l}0.272 \\
( \pm 0.161)\end{array}$ & $\begin{array}{l}0.244 \\
( \pm 0.146)\end{array}$ & $\begin{array}{l}0.325 \\
( \pm 0.187)\end{array}$ & $\begin{array}{l}0.286 \\
( \pm 0.169)\end{array}$ & $\begin{array}{l}0.311 \\
( \pm 0.177)\end{array}$ & $\begin{array}{l}0.733 \\
( \pm 0.581)\end{array}$ \\
\hline $\begin{array}{l}\text { NO3-N } \\
(\mathrm{mg} / \mathrm{l})- \\
\text { Elsner }\end{array}$ & $\begin{array}{l}1.49 \\
( \pm 0.22)\end{array}$ & $\begin{array}{l}1.56 \\
( \pm 0.22)\end{array}$ & $\begin{array}{l}1.59 \\
( \pm 0.21)\end{array}$ & $\begin{array}{l}1.51 \\
( \pm 0.23)\end{array}$ & $\begin{array}{l}1.57 \\
( \pm 0.21)\end{array}$ & $\begin{array}{l}1.52 \\
( \pm 0.21)\end{array}$ & $\begin{array}{l}1.55 \\
( \pm 0.2)\end{array}$ \\
\hline $\begin{array}{l}\text { NO3-N } \\
\text { (mg/l) - } \\
\text { Stafford }\end{array}$ & $\begin{array}{l}1.52 \\
( \pm 0.25)\end{array}$ & $\begin{array}{l}1.53 \\
( \pm 0.23)\end{array}$ & $\begin{array}{l}1.56 \\
( \pm 0.23)\end{array}$ & $\begin{array}{l}1.52 \\
( \pm 0.26)\end{array}$ & $\begin{array}{l}1.54 \\
( \pm 0.23)\end{array}$ & $\begin{array}{l}1.57 \\
( \pm 0.26)\end{array}$ & $\begin{array}{l}2.21 \\
( \pm 0.53)\end{array}$ \\
\hline
\end{tabular}


TABLE IV

ALTERNATIVE RANKINGS AND MODEL PREDICTED CHANGES IN CRITICAL WATER QUALITY PARAMETERS RELATIVE TO BASE CASE

\begin{tabular}{|c|c|c|c|c|c|c|c|}
\hline $\begin{array}{l}\text { Rank / } \\
\text { Alternative }\end{array}$ & $\begin{array}{l}\text { change } \\
\text { in algae } \\
\text { conc. at } \\
\text { Stafford }\end{array}$ & $\begin{array}{l}\text { change } \\
\text { in } \\
\text { algae } \\
\text { conc. } \\
\text { at } \\
\text { Elsner }\end{array}$ & $\begin{array}{l}\text { change } \\
\text { in DO } \\
\text { conc. at } \\
\text { stafford }\end{array}$ & $\begin{array}{l}\text { change } \\
\text { in pH at } \\
\text { stafford }\end{array}$ & $\begin{array}{l}\text { change in } \\
\text { space-time } \\
\text { averaged } \\
\text { chloro- } \\
\text { phyll-a } \\
\text { violations }\end{array}$ & $\begin{array}{l}\text { change in } \\
\text { space-time } \\
\text { averaged } \\
\text { Do } \\
\text { violations }\end{array}$ & $\begin{array}{l}\text { change } \\
\text { in } \\
\text { space- } \\
\text { time } \\
\text { averaged } \\
\text { pH viol- } \\
\text { ations }\end{array}$ \\
\hline $\begin{array}{l}\text { (1) } 200 \mathrm{cfs} \\
\text { flow } \\
\text { augmentation }\end{array}$ & $-32 \%$ & $-54 \%$ & $-1 \%$ & $-4 \%$ & $-45 \%$ & $-21 \%$ & $-92 \%$ \\
\hline $\begin{array}{l}\text { (2) } 100 \text { cfs } \\
\text { flow } \\
\text { augmentation } \\
+ \text { flash } \\
\text { boards down }\end{array}$ & $-21 \%$ & $-47 \%$ & $-3 \%$ & $-3 \%$ & $-28 \%$ & $-20 \%$ & $-75 \%$ \\
\hline $\begin{array}{l}\text { (3) } 100 \mathrm{cfs} \\
\text { flow } \\
\text { augmentation }\end{array}$ & $-6 \%$ & $-35 \%$ & $+4 \%$ & $-1 \%$ & $-21 \%$ & $-16 \%$ & $-72 \%$ \\
\hline $\begin{array}{l}\text { (4) } 50 \% \\
\text { phosphorus } \\
\text { reduction in } \\
\text { tributaries }\end{array}$ & $-17 \%$ & $-23 \%$ & $-9 \%$ & $-1 \%$ & $-11 \%$ & $+8 \%$ & $-72 \%$ \\
\hline
\end{tabular}




\begin{tabular}{||l||l|l|l|l|l|l|l||}
\hline $\begin{array}{l}\text { Rank / } \\
\text { Alternative }\end{array}$ & $\begin{array}{l}\text { change } \\
\text { in algae } \\
\text { conc. at } \\
\text { Stafford }\end{array}$ & $\begin{array}{l}\text { change } \\
\text { in } \\
\text { algae } \\
\text { conc. } \\
\text { at } \\
\text { Elsner }\end{array}$ & $\begin{array}{l}\text { change } \\
\text { in DO } \\
\text { conc. at } \\
\text { Stafford }\end{array}$ & $\begin{array}{l}\text { change } \\
\text { in pH at } \\
\text { Stafford }\end{array}$ & $\begin{array}{l}\text { change in } \\
\text { space-time } \\
\text { averaged } \\
\text { chloro- } \\
\text { phyll-a } \\
\text { violations }\end{array}$ & $\begin{array}{l}\text { change in } \\
\text { space-time } \\
\text { averaged } \\
\text { Do } \\
\text { violations }\end{array}$ & $\begin{array}{l}\text { change } \\
\text { in } \\
\text { space- } \\
\text { time } \\
\text { averaged } \\
\text { pH viol- } \\
\text { ations }\end{array}$ \\
\hline \hline $\begin{array}{l}\text { (5) Flash } \\
\text { boards down } \\
\text { on diversion } \\
\text { dam }\end{array}$ & $+2 \%$ & $-14 \%$ & $-3 \%$ & $0 \%$ & $-7 \%$ & $-24 \%$ & $-37 \%$ \\
\hline $\begin{array}{l}\text { (6) No } \\
\text { diversion } \\
\text { dam }\end{array}$ & $+61 \%$ & $-40 \%$ & $-53 \%$ & $+4 \%$ & $-23 \%$ & $+62 \%$ & $+140 \%$ \\
\hline
\end{tabular}


The "no diversion dam" alternative caused the most water quality violations. Dissolved oxygen and $\mathrm{pH}$ violations were much larger for this alternative than for the other options, including the base case. Although the mean algae concentration (chlorophyll-a) at Elsner decreased with respect to the base case by $40 \%$, it increased at Stafford by $61 \%$. This effect was caused by the warmer water temperatures at stafford producing more optimal growth conditions. The shallow water conditions created by removing the diversion dam made the lower pool area more susceptible to solar heating.

Greater algae biomass also resulted in larger swings in $\mathrm{pH}$ and dissolved oxygen, and anaerobic conditions became more prevalent because of increased biochemical oxygen demand. Anaerobic decomposition of the sediments released orthophosphorus and ammonia-nitrogen into the water column, further stimulating algal growth. This effect was represented by increased nutrient concentrations at stafford (Table III) . 
Chlorophyll a Violations

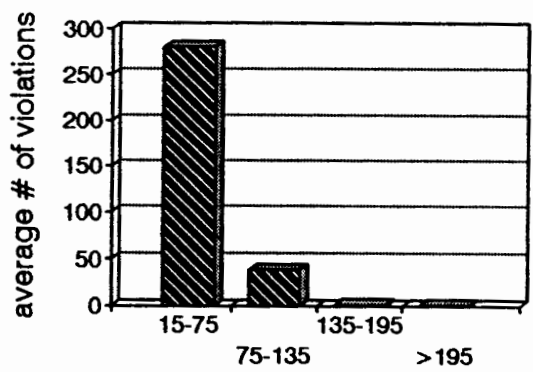

Chiorophyll a (ug/l)
Dissolved Oxygen Violations

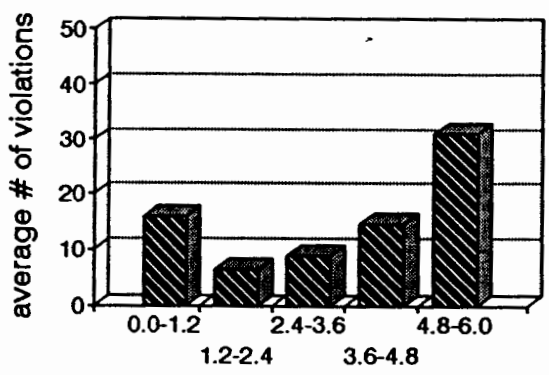

Dissolved Oxygen (mg/l)

$\begin{array}{lrlrl}\text { Mean Violation } & 35.4 & \mathrm{ug} / \mathrm{l} & \text { Mean Violation } & 3.7 \mathrm{mg} / \mathrm{l} \\ \text { Histogram Total } & 320.8 & \text { Histogram Total } & 76.5\end{array}$

$\mathrm{pH}$ Violations

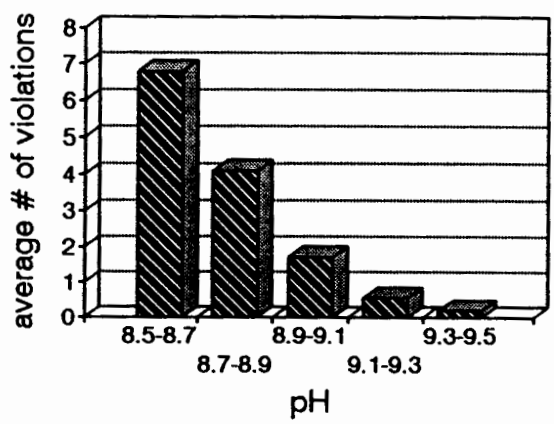

Mean Violation

8.7

Histogram Total

13.4

Figure 33. Histograms showing water quality violations for the base case. 
Chlorophyll a Violations

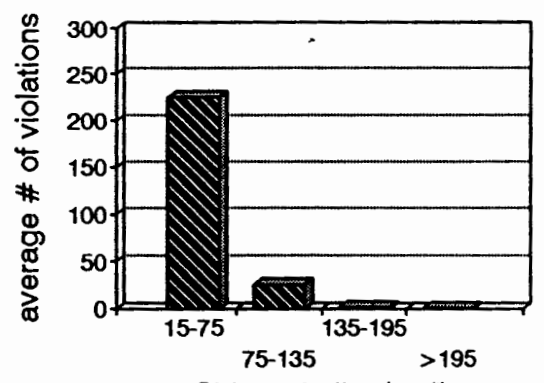

Chiorophyll a (ug/i) $\begin{array}{lrl}\text { Mean Violation } & 28.8 \mathrm{ug} / \mathrm{l} \\ \text { Histogram Total } & 253.0\end{array}$
pH Violations

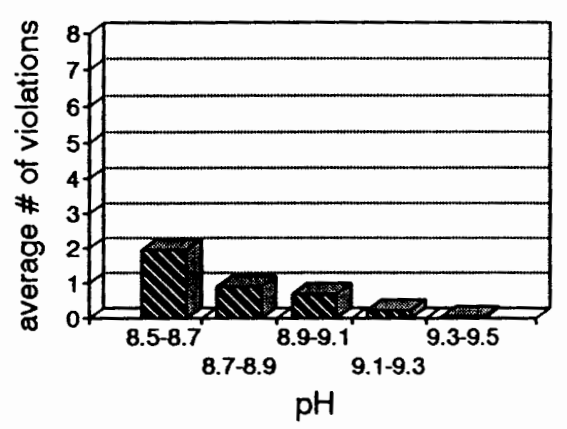

Dissolved Oxygen Violations

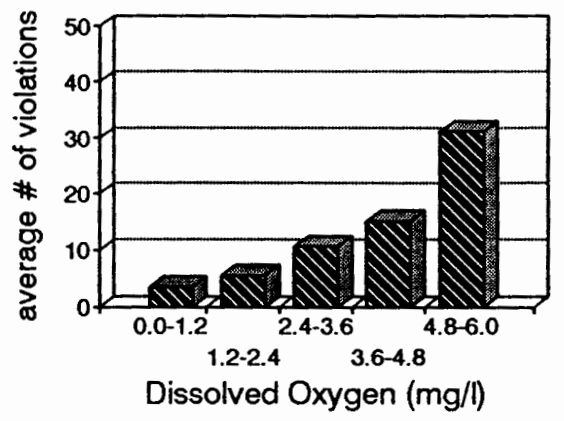

Mean Violation

Histogram Total
$4.5 \mathrm{mg} / \mathrm{l}$

66.0
Mean Violation

Histogram Total
8.7

3.8

Figure 34. Histograms showing water quality violations for the $100 \mathrm{cfs}$ flow augmentation alternative. 
Chlorophyll a Violations

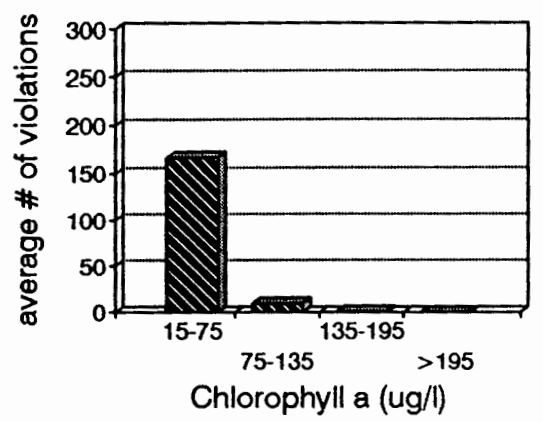

Mean Violation

Histogram Total
$24.0 \mathrm{ug} / 1$
176.9

$\mathrm{pH}$ Violations

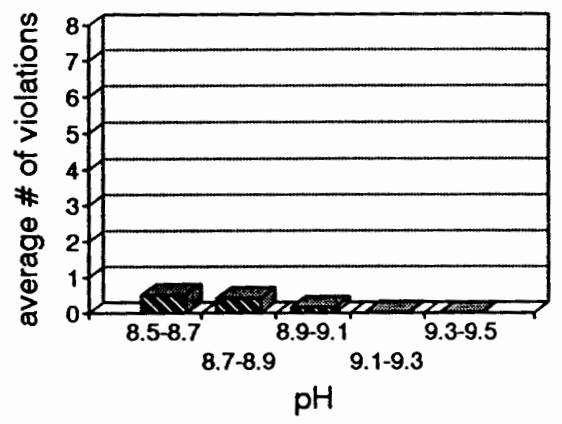

Dissolved Oxygen Violations

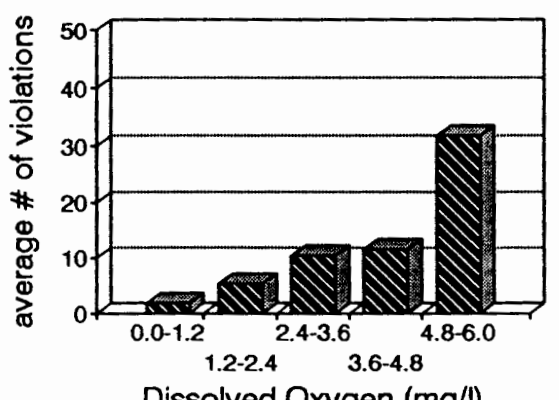

Dissolved Oxygen (mg/l)
Mean Violation

Histogram Total
$5.0 \mathrm{mg} / \mathrm{l}$

60.7
Mean Violation

Histogram Total
8.7

1.1

Figure 35. Histograms showing water quality violations for the $200 \mathrm{cfs}$ flow augmentation alternative. 
Chlorophyll a Violations

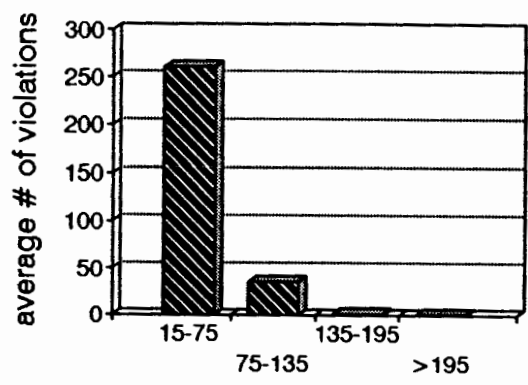

Chiorophyll a (ug/l)

\section{Dissolved Oxygen Violations}

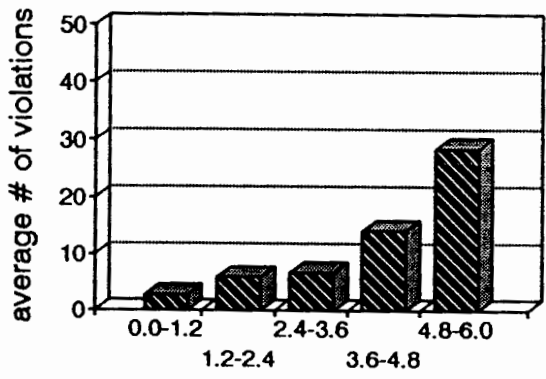

Dissolved Oxygen (mg/l) $\begin{array}{lrl}\text { Mean Violation } & 32.9 \mathrm{ug} / \mathrm{l} \\ \text { Histogram Total } & 297.8\end{array}$

pH Violations

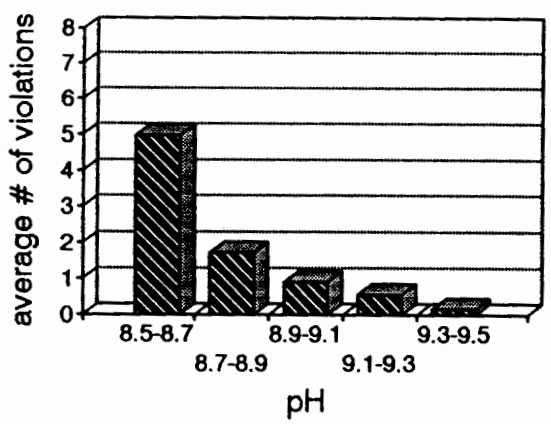

Mean Violation

Histogram Total
$4.2 \mathrm{mg} / \mathrm{l}$

58.1
Mean Violation Histogram Total
8.7

8.4

Figure 36. Histograms showing water quality violations for the flash boards down alternative. 
Chlorophyll a Violations

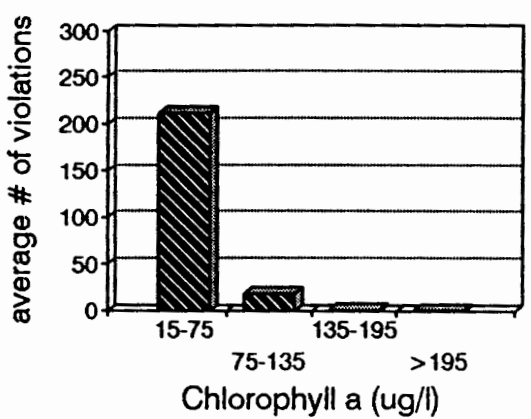

Mean Violation Histogram Total

$27.1 \mathrm{ug} / \mathrm{i}$ 231.5

pH Violations

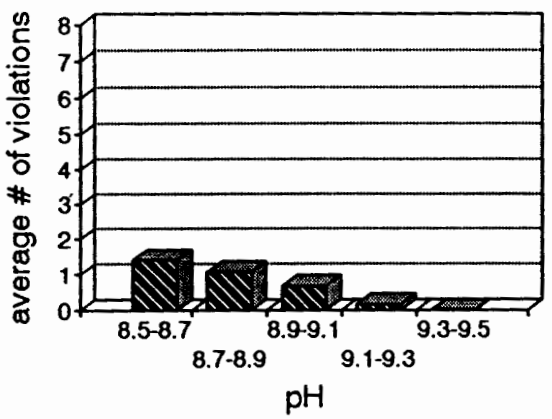

Dissolved Oxygen Violations

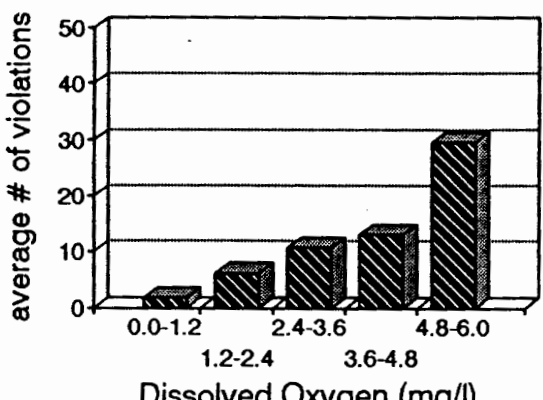

Dissolved Oxygen (mg/l)
Mean Violation

Histogram Total
$4.4 \mathrm{mg} / \mathrm{l}$

61.3

Mean Violation

8.7

Histogram Total

3.3

Figure 37. Histograms showing water quality violations for the 100 cfs flow augmentation and flash boards down alternative. 
Chlorophyll a Violations

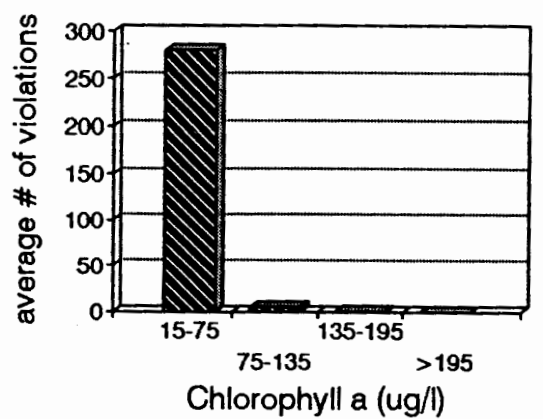

Mean Violation

Histogram Total
$29.3 \mathrm{ug} / \mathrm{l}$

286.3
Dissolved Oxygen Violations

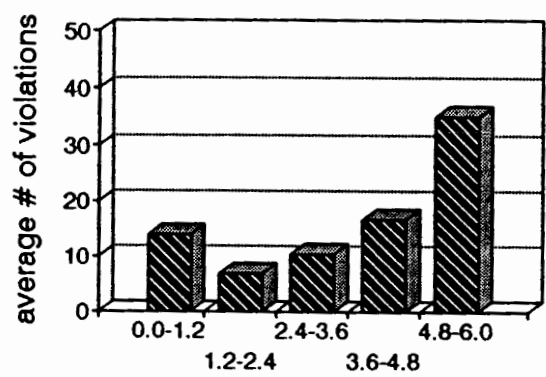

Dissolved Oxygen (mg/l)
Mean Violation

Histogram Total
$3.8 \mathrm{mg} / \mathrm{l}$

83.0

$\mathrm{pH}$ Violations

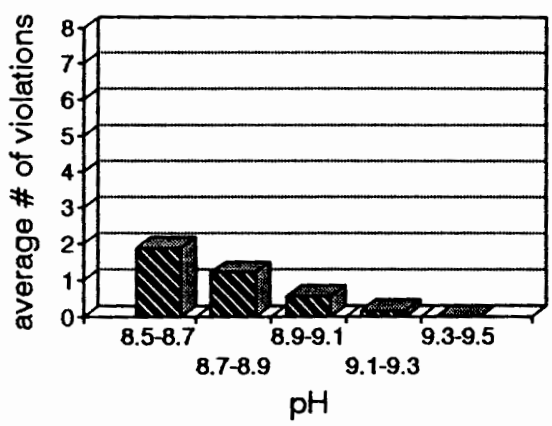

Mean Violation

8.7

Histogram Total

3.8

Figure 38. Histograms showing water quality violations for the $50 \%$ reduction in phosphorus loading alternative. 
Chlorophyll a Violations

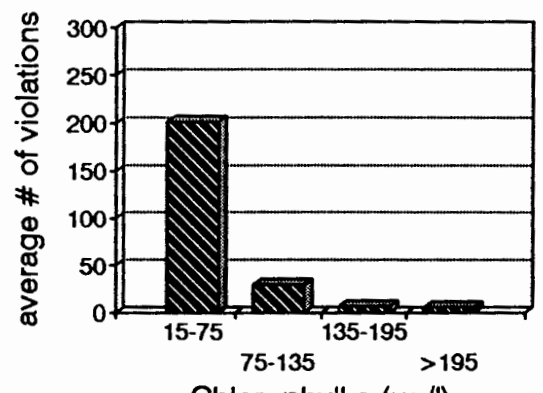

Chlorophyll a (ug/l)
Dissolved Oxygen Violations

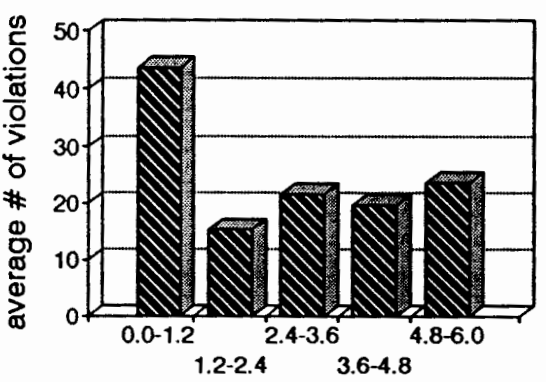

Dissolved Oxygen (mg/l)
Mean Violation

Histogram Total
$51.9 \mathrm{ug} / \mathrm{l}$

245.6
Mean Violation

Histogram Total
$3.1 \mathrm{mg} / \mathrm{l}$

123.8

Mean Violation

pH Violations

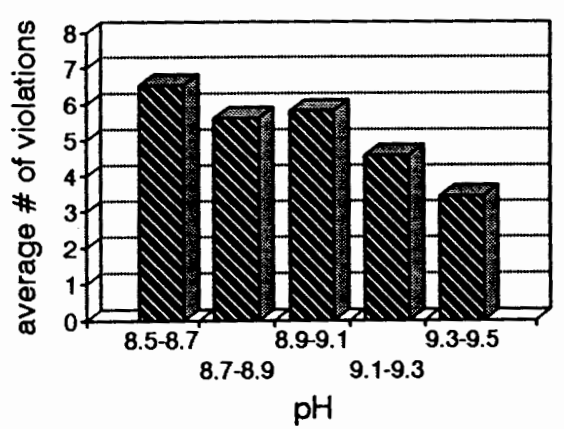

Histogram Total

9.0

32.1

Figure 39. Histograms showing Water Quality Violations for the No Dam Alternative 


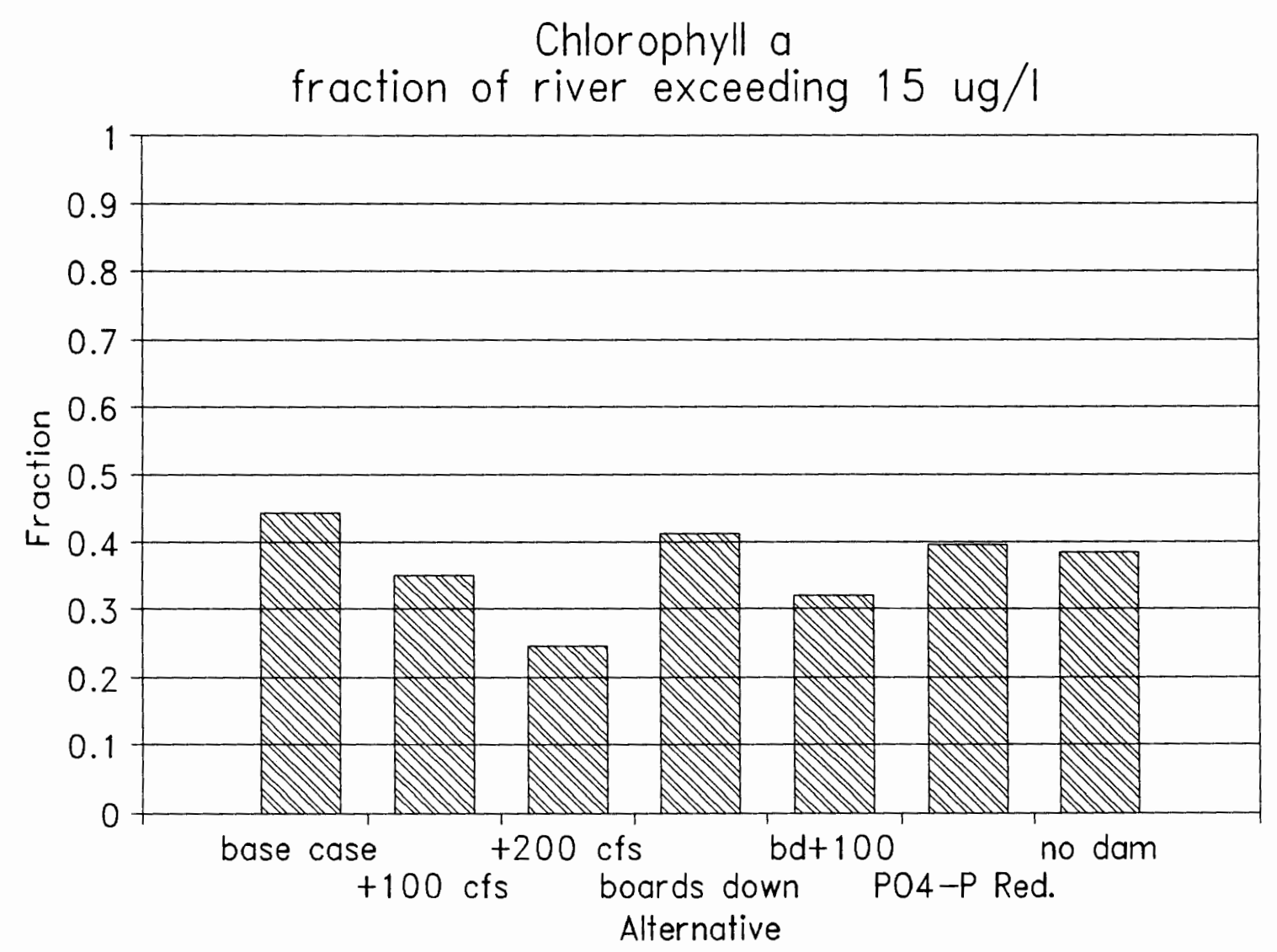

Figure 40. Bar graph showing the time-averaged fraction of river volume violating chlorophyll-a standards for each of the management alternatives. 


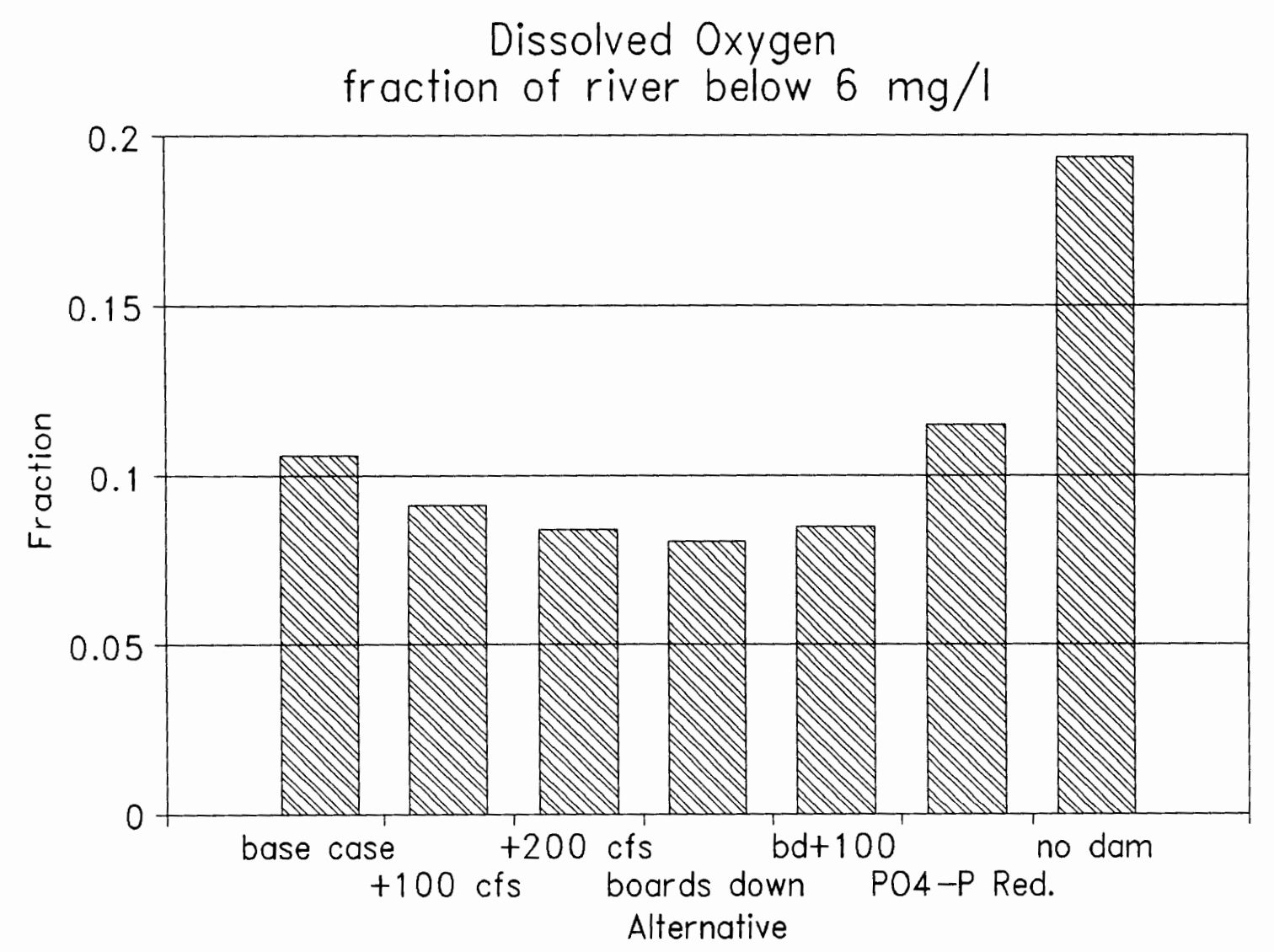

Figure 41. Bar graph showing the time-averaged fraction of river volume violating dissolved oxygen standards for each of the management alternatives. 


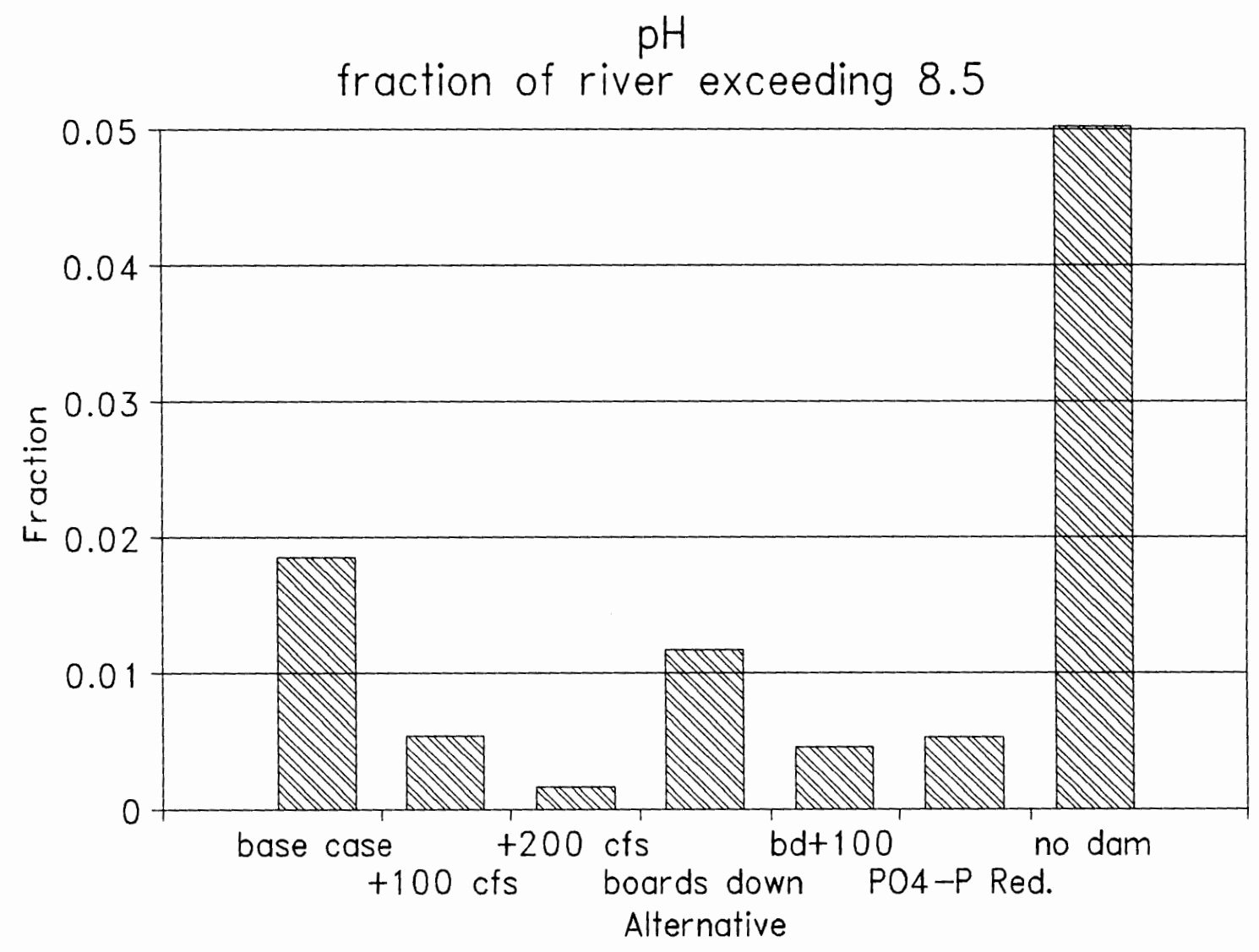

Figure 42. Bar graph showing the time-averaged fraction of river volume violating pH standards for each of the management alternatives. 
SUMMARY

This thesis discusses the development and application of a water quality and hydrodynamic model simulating the lower Tualatin River from river mile 32 to the Lake oswego diversion dam at river mile 3.5. Topics described include model formulation and design, model calibration and verification, and the design and evaluation of management alternatives

The in-stream water quality model used for evaluating the management alternatives was an adaptation of the corps of Engineers' model CE-QUAL-W2 (Corps of Engineers, 1986,1990). CE-QUAL-W2 is a two-dimensional, laterally averaged, dynamic model of hydrodynamics and water quality. It can predict water surface elevations, velocities, temperatures along with the kinetics, transport, and interactions of up to 22 water quality constituents. The constituents modeled included: inorganic suspended solids, total dissolved solids, refractory and labile dissolved organic matter, algae, detritus, phosphorus (orthophosphorus, $\left.\mathrm{PO}_{4}-\mathrm{P}\right)$, ammonia-nitrogen $\left(\mathrm{NH}_{3}-\mathrm{N}\right)$, nitratenitrogen $\left(\mathrm{NO}_{3}-\mathrm{N}\right)$, dissolved oxygen, inorganic carbon, alkalinity, pH, carbon dioxide, bicarbonate, carbonate, and zooplankton.

CE-QUAL-W2 was ideally suited for simulating the lower Tualatin. The lower river is analogous to a long, narrow reservoir that has significant water quality and temperature 
gradients vertically and longitudinally. The model was well matched to the river's topography because its twodimensional domain corresponds to the river's vertical and longitudinal directions. For narrow water bodies like the Tualatin River, the lateral, or width-wise variations in hydrodynamic and water quality parameters are negligible.

The two-dimensional CE-QUAL-W2 has an advantage over one-dimensional models because it was able to simulate the downstream movement of algae and suspended solids in conjunction with movement resulting from settling or vertical velocities. The model was also versatile enough that algorithms can be added which simulate the hydrodynamic and water quality effects of the diversion dam.

Model calibration was a process whereby model predictions of hydrodynamics, temperature, and water quality constituents, were compared with field data after adjusting parameters. Calibration of hydrodynamics and temperature were straight forward because field data were plentiful and the model was sophisticated and flexible enough to simulate river flow patterns and heating. Calibration of water quality parameters was more complicated. Because of the close link between phytoplankton and water quality, some of the most critical parameters calibrated were the ones controlling algal dynamics. Of special importance were the estimation of zooplankton inflow concentrations, which was done by inferring their grazing effect on algal 
concentrations. For the summer of 1991, there were several late summer algal blooms which occurred at Elsner but seemed to dwindle when they reached stafford. Early summer algal blooms, in contrast, were larger at stafford than at Elsner. It had been observed that zooplankton were more prevalent in the lower pool area near stafford than upriver. A fairly close fit for chlorophyll-a concentration was obtained at Elsner and stafford by adjusting the inflow zooplankton concentrations so that they were small enough not to substantially effect algal concentrations at Elsner. The zooplankton growth rate, however, was large enough so that by the time the zooplankton population had reached stafford, further downriver, they had begun to limit the algal concentrations. This effect was restricted to the late summer by gradually increasing the zooplankton inflow concentrations through the summer.

Following model calibration and verification, modifications were made to the model corresponding to different pollution control alternatives. The management alternatives evaluated were flow augmentation, Lake oswego diversion dam removal, tributary phosphorus load reduction, leaving the diversion dam flash boards down, and combinations of these alternatives. Scenario results were compared using statistical criteria describing temperature, $\mathrm{pH}$, and constituent concentrations.

The management alternatives producing the greatest 
improvements in water quality were those employing flow augmentation. Greater inflows into the lower Tualatin River created shorter detention times and colder water temperatures, providing less favorable growth conditions for phytoplankton. On the other hand, the alternatives which lowered the water surface elevations on the river - the flash boards down and the no diversion dam alternatives actually worsened water quality conditions in the river between the Durham wastewater treatment plant and the diversion dam. This was caused by the warmer water temperatures producing more optimal growth conditions. Warmer temperatures were the result of shallowness and reduced river volume created by the lower water surface elevations, making the river more susceptible to solar heating.

The model does a fairly effective job in simulating the hydrodynamics and most of the relevant water quality trends occurring in the lower Tualatin River. As with all models, simplifications were necessary to make the problem manageable. A limitation of the model was the existence of only one algal compartment, preventing the modeling of the seasonal succession of algal species. The use of only one wind sheltering coefficient was another limitation. The model uses a constant value for all longitudinal cells rather than assigning a particular value for each river cell, resulting in a slight over prediction in temperatures 
in the lower pool. Also presenting problems was the lack of zooplankton inflow concentrations, which had to be estimated and are believed to have a major impact on algae concentrations in the downstream end of the pool area. Despite these Iimitations, it is believed that the phenomena relevant to the project goals were adequately simulated. 


\section{REFERENCES}

Ahlgren, I., T. Frisk and I. Kamp-Nielsen. 1988. Empirical and Theoretical Models of Phosphorus Loading, Retention and Concentration vs. Lake Trophic state. Hydrobiologia. 170:285-303.

Bierman, V. J. 1976. Mathematical Model of the Selective Enrichment of Blue-Green Algae by Nutrient Enrichment. In Modeling of Biochemical Processes in Aquatic Ecosystems. R. P. Canale, Editor. Ann Arbor, MI. Ann Arbor science Publishers, Inc. p. 1.

Bloomfield, J. A., R. A. Park, D. Scavia and C.S. Zahorcak. 1973. Aquatic Modeling in the EDFB, US-IBP. In Modeling the Eutrophication Process. E. J. MIddlebrooks, et al., Editors. Ann Arbor, MI. Ann Arbor Science Publishers, Inc. p. 139.

Butts, T. A: and Evans, R. L. 1983. Small Stream Channel Dam Aeration Characteristics. Journal Environmental Engineering Division, ASCE. 109(3): 555-573.

Cass, P. L., and R. Miner. 1993. Historical Tualatin River Basin. Water Resources Research Institute and oregon State University Extension Service. Corvallis, Oregon.

Chapra, S. C. 1975. Comment on 'An empirical method of estimating the retention of phosphorus in lakes' by $W$. B. Kirchner and P. J. Dillon. Water Resources Research, $11: 1033-1034$.

Chapra, S. C., and S. J. Tarachak, 1976. A Chlorophyll a Model and Its Relationship to Phosphorus Loading Plots for Lakes. Water Resources Research. 12:1260-1264.

Chapra, S. C. and K. H. Reckhow. 1983. Engineering Approaches for lake Management. Butterworth Publishers. Boston.

Chen, C. W. 1970. Concepts and Utilities of Ecologic Models. Journal Sanitary Engineering. ASCE. 96(SA5) :1085-1086.

Chen, C. W. and G. I. Orlob. 1975. Ecologic Simulation for Aquatic Environments. In B. C. Patten (ed.) Systems Analysis and Simulation in Ecology, Vol. 3, Academic Press. New York: 475-588. 
CH2MHill. 1988. Tualatin River Water Quality Modeling Study. Prepared for Unified Sewerage Agency. P21262.Fo.

Corps of Engineers. 1953. Review of Survey Report on Tualatin River oregon. Portland, oregon.

Corps of Engineers. 1978. Water Quality for River/Reservoir Systems -- Model Documentation. Hydrologic Engineering Center, Corps of Engineers. Davis, California.

Corps of Engineers. 1982. Tualatin River Channel Improvements: Tualatin, Oregon. Portland, Oregon.

Corps of Engineers. 1986a. CE-QUAL-W2: A Numerical TwoDimensional, Laterally Averaged Model of Hydrodynamics and Water Quality: User's Manual. Environmental and Hydraulics Laboratory. Waterways Experiments Station. Vicksburg, Mississippi.

Corps of Engineers. 1990. DRAFT - Updated CE-QUAL-W2 User'S Manual. Waterways Experiment station. Vicksburg, Mississippi.

Cowen, W. F. and G. F. Lee. 1976. Algal Nutrient Availability and Limitation in Lake ontario during IFYGL Part 1. Available Phosphorus in Urban Runoff and Lake Ontario Tributary Waters. U. S. Environmental Protection Agency. Corvallis, OR. EPA-600/2-76-094a.

Dillon, P. J. and F. H. Rigler. 1974. The PhosphorusChlorophyll Relationship in Lakes. Limnology Oceanography. 19:767-773.

Dillon, P.J. and W. B. Kirchner. 1975. Reply. Water Resources Research. 11:1035-1036.

Di Toro, D. M., R. V. Thomann and D. J. O'Connor. 1971. A Dynamic Model of Phytoplankton population in the Sacramento-San Joaquin Delta. In Advances in Chemistry Series 106: Nonequilibrium Systems in Natural Water Chemistry. R.F. Gould, Editor. Washington, DC: American Chemical Society, p. 131.

Edinger, J. E. and Geyer, J. C. 1965. Heat Exchange in the Environment. Research Project No. 49. Department of Sanitary Engineering. The Johns Hopkins University. Baltimore, Maryland. 
Edinger, J. E. and Buchak, E. M. 1978. Numerical Hydrodynamics of Estuaries. Estuarine and Wetland Processes with Special Emphasis on Modeling, ed. by P. Hamilton and K. B. MacDonald, Plenum Press, NY, 115146.

Eiker, E. E. 1972. Thermal Simulation of Lakes. Corps of Engineers, Program No. 722-F5-E1010, Baltimore, Maryland.

Gupta, H. 1990. Hydrology and Hydraulics. McGraw-Hill. New York.

Herbes, S. E. 1974. Biological Utilization of Dissolved Organic Phosphorus in Natural waters. PhD Thesis. University of Michigan. Ann Arbor, MI.

Hubbard, L. E., Herrett, T. A., Kraus, R.I., and Kroll, C. G. 1990. 1990-Water Resources Data Oregon Water Year 1990. Volume 2. U.S. Geological Survey. Water Data Report OR-90-2. p.168.

Hubbard, L. E., Herrett, T. A., Kraus, R.I., and Kroll, C. G. 1991. 1991-Water Resources Data Oregon Water Year 1991. U.S. Geological Survey, Water Data Report OR-911, p. 310 .

Imboden, D. M. 1975. Phosphorus Models of Lake Eutrophication. Limnology Oceanography. 19:297-304.

Kamp-Nielson, L. 1977. Modeling the Temporal Variation In Sedimentary Phosphorus Fractions. In Proceedings of the Symposium on Interactions between Sediments and Fresh Water, H. I. Golterman (ed). Amsterdam. 277-285

Knutson, M. 1993. Modeling of Flow and Water Quality in Henry Hagg Lake Near Forest Grove, Oregon. Masters Thesis. Portland State University. Portland, Oregon. Technical Report EWR-004-93.

LaLiberte, David M. 1991. Bybee and Smith Lake Discharge Models. Civil Engineering Department, Portland State University. Portland, Oregon.

Larsen, D. P., H. T. Mercier and K. W. Malueg. 1973. Modeling Algal Growth Dynamics in Shagawa Lake, Minnesota, with Comments Concerning Projected Restoration of the Lake. In Modeling the eutrophication Process. E. J. Middlebrooks, et. al. Editors. Ann Arbor MI. Ann Arbor Science Publishers, Inc. p. 15. 
Leonard, B. P. 1979. A Stable and Accurate Convection Modelling Procedure Based on Quadratic Upstream Interpolation. Comput. Methods Appl. Mech. Engr., 19, 59-98.

Linsley, R.K. and Franzini, J.B. 1979. Water Resources Engineering, 3rd ed., McGraw-Hill Book Company.

Lorenzon, M. W. 1974. Predicting the Effects of Nutrient Diversion in Lake Recovery. In Modeling the Eutrophication Process, E. J. Middlebrooks et. al. Eds. Ann Arbor, MI: Ann Arbor Science Publishers, Inc.

Lorenzon, M. W., et al. 1974. Predicting the Effects of Nutrient Diversion on Lake Recovery. In Modeling the Eutrophication Process. E. J. Middlebrooks et al. (eds). Ann Arbor MI. Ann Arbor Science Publishers, Inc.

Lung, W. S., et al. 1976. Phosphorus Models for Eutrophic Lakes. Water Resources. 10:1101-1114.

Miller, Jan. 1992. Personal communication. Unified Sewerage Agency. Hillsboro, Oregon.

National Oceanic and Atmospheric Administration. 1990, 1991. Local Climatological Data: Monthly summary. Portland, oregon, National Weather Service office, Portland International Airport, $5420 \mathrm{NE}$ Marine Dr., June 1990 thru April 1991.

O'Melia, C. R. 1972. An Approach to the Modeling of Lakes. Schweiz $\mathrm{Z}$. Hydrol. 34:1-34.

Park, R. A., et al. 1974. A General Model for Simulating Lake Ecosystems. Simulation. $23(2): 33-50$.

Patten, B. C. et al. 1975. Total Ecosystem Model for a Cover in Lake Taxoma. In Systems Analysis and Simulation in Ecology, Vol. III. B. C. Patton, Editor. New York. Academic Press, Inc., p. 206.

Piontelli, R. and V. Tonoli. 1964. Il tempo di residenza della acque lacustri in relatione ai fenomeni di arricchimento in sostanze immensse, con particolare riguardo al Lago Maggiore. Mem. Ist ital. Idrobiol. 17:247-266.

Scavia, D. 1979. The Use of Ecological Models of Lakes in Synthesizing Available Information and Identifying Research Need. In D. Scavia and A. Robertson (eds.) Perspectives on Lake Ecosystem Modeling. Ann Arbor Science Publishers. Ann Arbor:109-168. 
Scavia, D. 1980. An Ecological Model for Lake Ontario. Ecological Modeling. 8:49-78.

Snodgrass, W. J. 1974. A Predictive Phosphorus Model for Lakes Development and Testing. Phd. Dissertation. University of North Carolina at Chapel Hill.

streeter, V. L. and Wylie, E. B. 1985. Fluid Mechanics, 8th edition. McGraw-Hill. pp. 374,375 .

Tang, Fei. 1993. Calibration and Verification of HSPF for Tualatin River Basin Water Quality. Civil Engineering Department, Portland State University. Portland, Oregon. Technical Report EWR-004-93.

Taylor, G. 1990,1991. Unpublished data. Oregon state climatologist. Oregon state University. Corvallis, oregon.

Tchobanoglous, G., and E. Schroeder. 1985. Water quality. Addison-Wesley Publishing.

Thomann, R. V., D. M. Di Toro, R. P. Winfield and D. J. O'Connor. 1975. Mathematical Modeling of Phytoplankton in Lake ontario. Model development and Verification. EPA-600/3-75-005. Corvallis, OR. U.S. Environmental Protection Agency.

Thomann, R. V. and J. S. Segna. 1980. Dynamic Phytoplankton-Phosphorus Verification and Simulations. In Phosphorus Management Strategies for Lakes, R. C. Loehr et al. (eds). Ann Arbor, MI. Ann Arbor Science Publishers, Inc. pp. 153-190.

Thomann, R. V., and J. S. Segna. 1980. Dynamic Phytoplankton-Phosphorus Model of Lake Ontario: TenYear Verification and simulations. In Phosphorus Strategies for Lakes, R. C. Loehr et al. (eds). Ann Arbor Science Publishers. Ann Arbor. pp. 153-205.

Thomann, R. V., and J. A. Mueller. 1987. Principles of Surface water Quality Modeling and Control. Harper Collins Publishers. New York.

Tualatin Valley Irrigation District. 1990,1991. Unpublished data. Hillsboro, Oregon.

Unified Sewerage Agency. 1990,1991. Unpublished data. Hillsboro, Oregon.

United states Geological Survey. 1991. Unpublished data, Portland, Oregon. 
U.S.G.S. Quadrangle Topographic Maps. Portland. Oregon.

U.S.G.S. 1991. Water Resources Data: Oregon Water Year 1991. Water-Data Report OR-91-1

Vaga, Ralph. 1992. Personal Communication. U.S.G.S. Portland.

Vollenweider, R. A. 1968. The Scientific Basis of Lake Eutrophication with Particular Reference to Phosphorus and Nitrogen as Eutrophication Factors. Organ. Econ. Coop. Dev. Paris. Technical report No. DAC/CSI68.27.

Vollenweider, R. A. 1975. Input-Output Models. With Special Reference to the Phosphorus Loading concept in Limnology. Schweiz. Z. Hydrol. 37:53-84.

Watermaster District 18. 1990,1991. Unpublished data. Hillsboro, Oregon.

Wells, S., C. Berger and M. Knutson. 1992. Modeling the Tualatin River System Including Scoggins Creek and Hagg Lake: Model Description, Geometry, and Forcing Data. Department of Civil Engineering, Portland state University. Technical Report EWR-010-92.

Wetzel, R. G. 1975. Limnology. W. B. Saunders Company. Philadelphia.

White, F.M. 1986. Fluid Mechanics, 2nd ed., McGraw-Hill Book Company, New York.

Wolf, D. W. 1992. A Literature Review: Land Use and Nonpoint Phosphorus Pollution in the Tualatin Basin, Oregon. Special Report 898. Oregon State University Extension Service and oregon water Resources Research Institute, Corvallis, Oregon. 


\section{APPENDIX A}

WATER QUALITY CYCLES IN CE-QUAL-W2

(Corps of Engineers, 1986a, 1990) 
APPENDIX A

WATER QUALITY CYCLES IN CE-QUAL-W2

(Corps of Engineers, 1986a, 1990) 
The source/sink term for each water quality constituent $\left(S_{k}\right.$ in equation 6$)$ in the $C E-Q U A L-W 2$ model are quantified in Table A-1. The water quality cycles that these equations correspond to are shown graphically in Figures A.1 through A.14 for algae, coliform, detritus, oxygen, inorganic carbon, suspended solids, labile dissolved organic matter, ammonia, nitrite+nitrate, ortho-phosphorus, refractory organic matter, sediment, iron, and zooplankton.

TABLE $A-1$

SOURCE SINK TERM EQUATIONS USED IN THE MODIFIED VERSION OF CE-QUAL-W2

\begin{tabular}{|c|l|c|c|}
\hline \hline 1 & $\begin{array}{c}\text { Parameter } \\
\text { Tracer } \\
\text { Conc. } \\
\left(\mathrm{g} / \mathrm{m}^{3}\right)\end{array}$ & $C_{1}$ & $S_{1}=0$ \\
\hline 2 & SS1 & $C_{2}$ & $S_{2}=\frac{\omega_{1} V C_{2}}{\Delta Z}$ \\
\hline 3 & $\begin{array}{l}\text { Coliform } \\
\text { Bacteria }\end{array}$ & $C_{3}$ & $S_{3}=-K_{\underline{c}} \theta^{(\underline{T}-20)} V C_{3}$ \\
\hline 4 & $\begin{array}{l}\text { Total Dissolved } \\
\text { Solids }\end{array}$ & $C_{4}$ & $S_{4}=0($ conservative $)$ \\
\hline
\end{tabular}




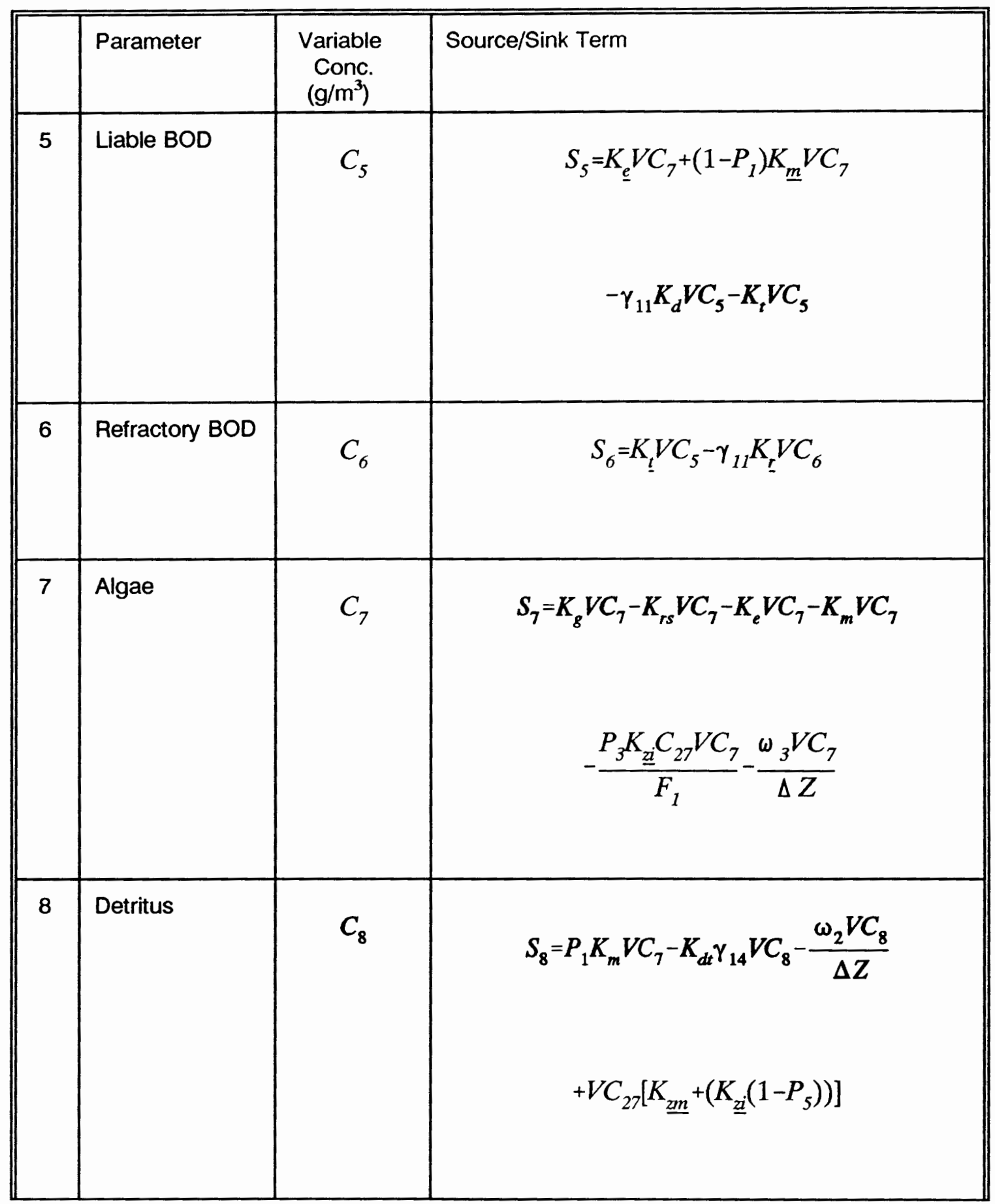




\begin{tabular}{|c|c|c|c|}
\hline & Parameter & $\begin{array}{c}\text { Variable } \\
\text { Conc. } \\
\left(\mathrm{g} / \mathrm{m}^{3}\right) \\
\end{array}$ & Source/Sink Term \\
\hline 9 & Phosphorus & $C_{9}$ & $\begin{array}{c}S_{g}=\left(K_{\underline{r g}}-K_{g}\right) \delta_{\underline{P}} V C_{7}+K_{\underline{d}} \delta_{\underline{P}} \gamma_{11} V C_{5}+K_{\underline{d d}} \delta_{\underline{P}} \gamma_{14} V C_{8} \\
+K_{\underline{r}} \delta_{\underline{P}} \gamma_{11} V C_{6}+K_{\underline{s}} \delta_{\underline{P}} \gamma_{16} \gamma_{26} C_{13}+X_{2} \gamma_{18} \gamma_{24} A_{\underline{s}} \\
-\frac{V A_{r} A_{2}\left(\omega_{1} C_{2}+\omega_{2} C_{8}+\omega_{3} C_{7}+\beta \omega_{4} C_{20}\right) C_{9}}{\Delta Z} \\
+V K_{2 r} C_{27} R_{3}\end{array}$ \\
\hline 10 & $\begin{array}{l}\text { Ammonia- } \\
\text { Nitrogen }\end{array}$ & $C_{10}$ & 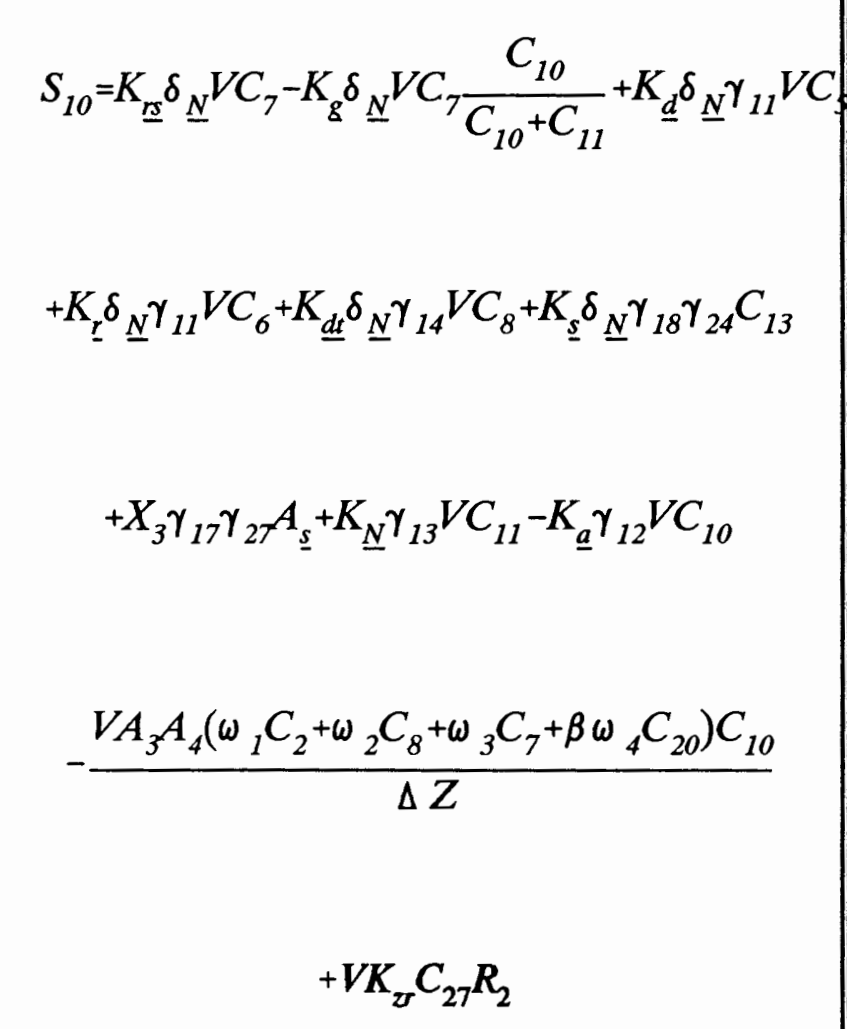 \\
\hline
\end{tabular}




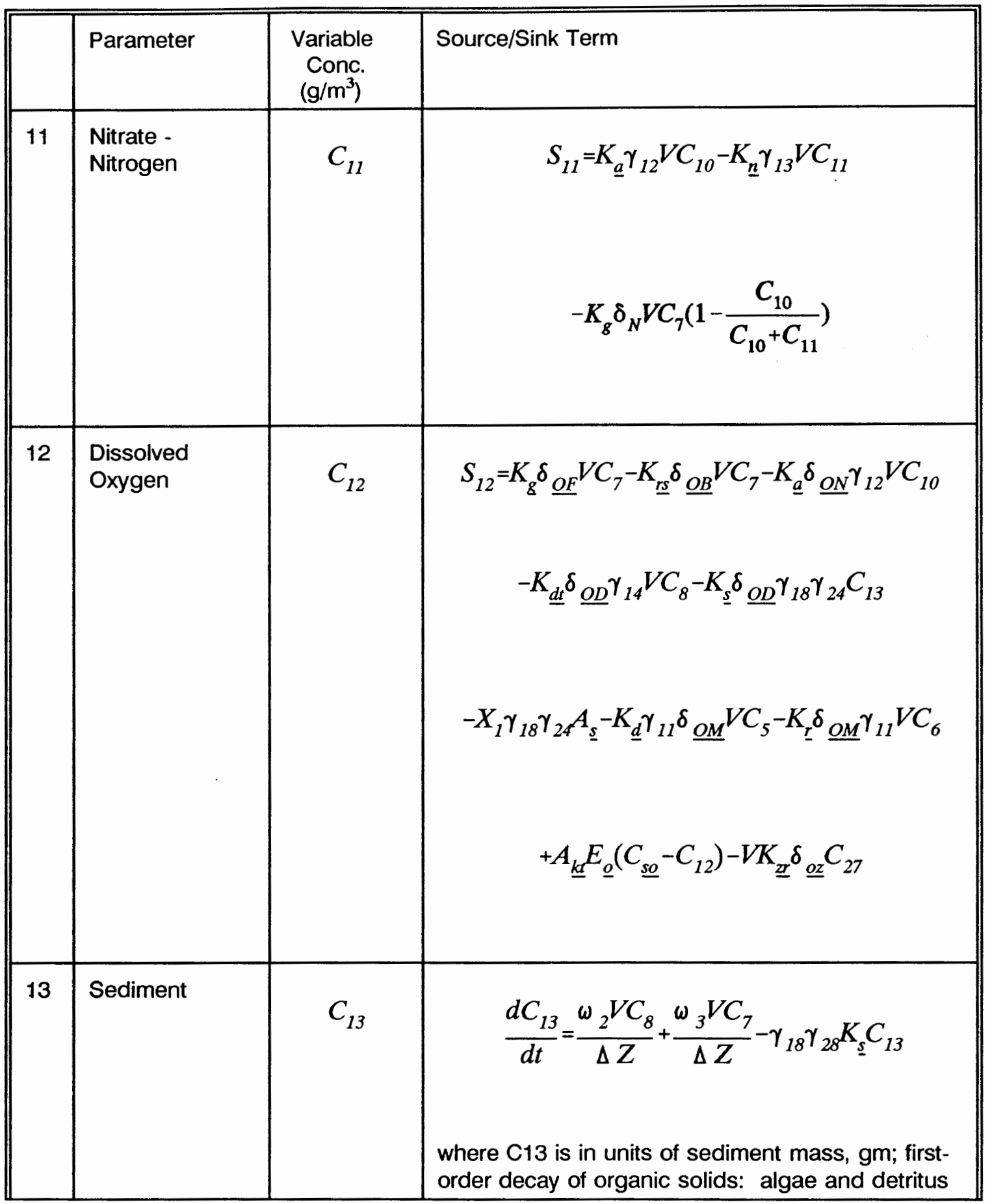




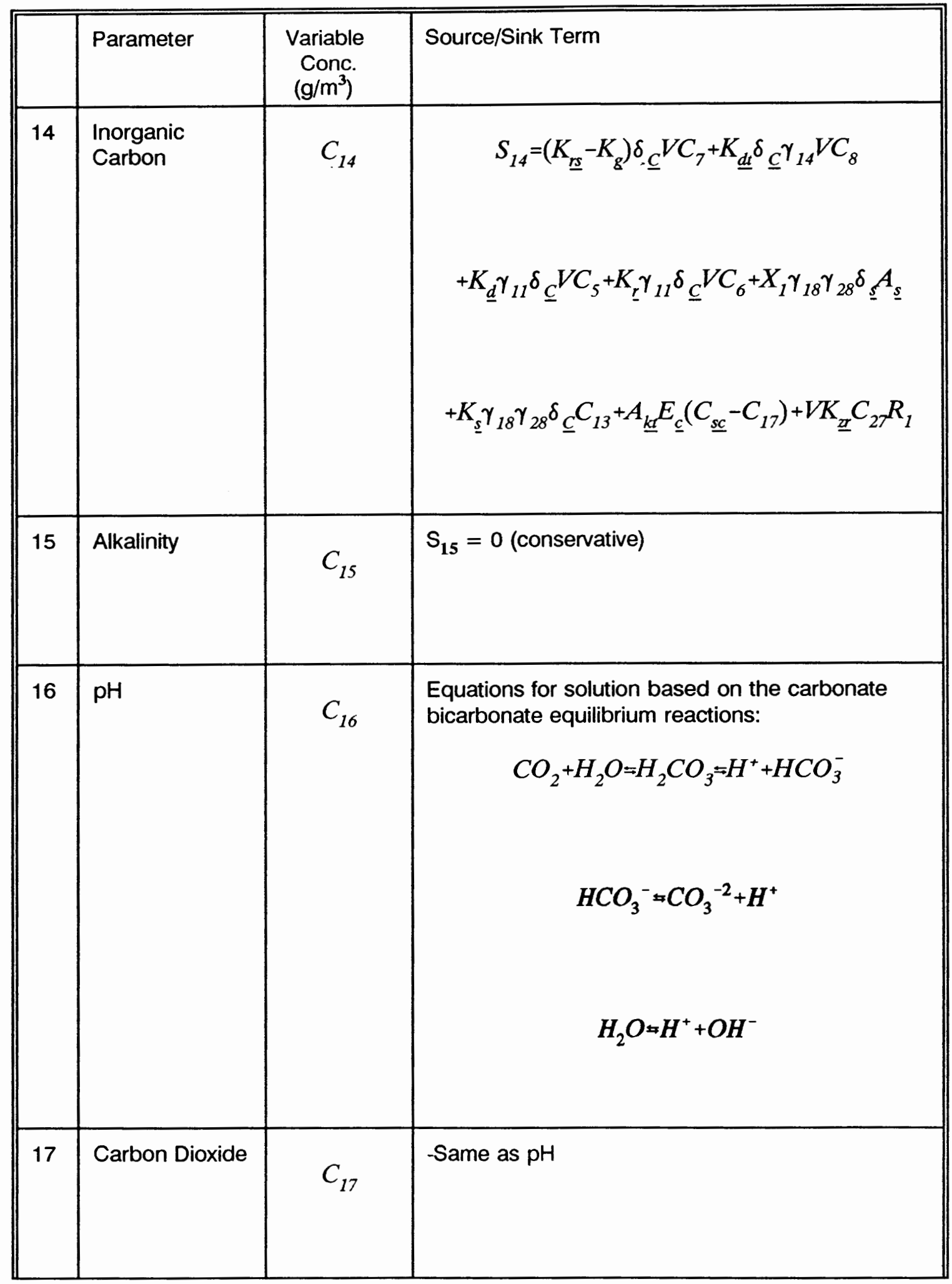




\begin{tabular}{|c|c|c|c|}
\hline & Parameter & $\begin{array}{c}\text { Variable } \\
\text { Conc. } \\
\left(\mathrm{g} / \mathrm{m}^{3}\right) \\
\end{array}$ & Source/Sink Term \\
\hline 18 & Bicarbonate & $C_{18}$ & -Same as $\mathrm{pH}$ \\
\hline 19 & Carbonate & $C_{19}$ & -Same as $\mathrm{pH}$ \\
\hline 20 & Iron & $C_{20}$ & $S_{20}=X_{4} \gamma_{18} \gamma_{28} A_{\underline{s}}-\frac{V \omega{ }_{4} C_{20}}{\Delta Z}$ \\
\hline 21 & BOD-5 & $C_{21}$ & $S_{21}=-K_{\underline{b}} \theta \underline{T}-20 C_{21}$ \\
\hline 22 & Zooplankton & $C_{27}$ & $S_{27}=\gamma_{1} \gamma_{2} Z \underline{e}_{\text {max }}\left[\left(F_{1}-Z_{\underline{L}}\right) /\left(F_{1}+Z_{1 / 2}\right)\right] V C_{27}$ \\
\hline
\end{tabular}


Table A-2 provides variable definitions for the variables in Table $\mathrm{A}-1$. It also lists variable names that are in the modified CE-QUAL-W2 control file. Variables where "not used" is listed under "Control File" are either computed by the program, or not input by the user, but are variables "hard wired" into the actual program.

TABLE A-2

VARIABLE DEFINITIONS FOR WATER QUALITY CYCLE EQUATIONS USED IN CE-QUAL-W2

\begin{tabular}{|c|c|c|c|c|c|}
\hline $\begin{array}{l}\text { Control } \\
\text { File }\end{array}$ & $\begin{array}{l}\text { Eq. } \\
\text { Var. }\end{array}$ & Definition & $\begin{array}{l}\text { Control } \\
\text { File }\end{array}$ & $\begin{array}{l}\text { Eq. } \\
\text { Var. }\end{array}$ & Definition \\
\hline AHSP & $A_{1}$ & $\begin{array}{l}\mathrm{PO}_{4} \text { adsorption } \\
\text { coefficient, } \mathrm{m}^{3} / \mathrm{g}\end{array}$ & ALGDET & $P_{1}$ & $\begin{array}{l}\text { partition coefficient for } \\
\text { algal mortality }\end{array}$ \\
\hline PARTP & $A_{2}$ & $\begin{array}{l}\text { max. mass of } \\
\mathrm{PO}_{4} \text { adsorbed } \\
\text { per mass of } \\
\text { solids }\end{array}$ & $\begin{array}{l}\text { PREF1 } \\
\text { PREF2 }\end{array}$ & $\mathrm{P}_{3}$ & $\begin{array}{l}\text { preference factor of } \\
\text { zooplankton for algae }\end{array}$ \\
\hline AHSN & $A_{3}$ & $\begin{array}{l}\text { ammonia } \\
\text { adsorption } \\
\text { coefficient, } \mathrm{m}^{3} / \mathrm{g}\end{array}$ & $\mathrm{BIOC}$ & $R_{1}$ & $\begin{array}{l}\text { ratio between carbon } \\
\text { and organic matter }\end{array}$ \\
\hline PARTN & $A_{4}$ & $\begin{array}{l}\text { max. mass of } \\
\text { ammonia } \\
\text { adsorbed per } \\
\text { mass solids }\end{array}$ & BION & $\mathrm{R}_{2}$ & $\begin{array}{l}\text { ratio between nitrogen } \\
\text { and organic matter }\end{array}$ \\
\hline not used & $A_{k t}$ & $\begin{array}{l}\text { surface area of } \\
\text { upper model } \\
\text { cell, } \mathrm{m}^{2}\end{array}$ & BIOP & $\mathrm{R}_{3}$ & $\begin{array}{l}\text { ratio between } \\
\text { phosphorus and organic } \\
\text { matter }\end{array}$ \\
\hline not used & $A_{s}$ & $\begin{array}{l}\text { sediment area, } \\
\mathrm{m}^{2}\end{array}$ & TEMP & $T$ & $\begin{array}{l}\text { temperature of water, } \\
{ }^{\circ} \mathrm{C}\end{array}$ \\
\hline not used & $\mathrm{C}_{\mathrm{sc}}$ & $\begin{array}{l}\text { carbon dioxide } \\
\text { saturation } \\
\text { concentration, } \\
\mathrm{g} / \mathrm{m}^{3}\end{array}$ & not used & v & cell volume, $\mathrm{m}^{3}$ \\
\hline
\end{tabular}




\begin{tabular}{|c|c|c|c|c|c|}
\hline $\begin{array}{l}\text { Control } \\
\text { File }\end{array}$ & $\begin{array}{l}\text { Eq. } \\
\text { Var. }\end{array}$ & Definition & $\begin{array}{l}\text { Control } \\
\text { File }\end{array}$ & $\begin{array}{l}\text { Eq. } \\
\text { Var. }\end{array}$ & Definition \\
\hline not used & $\mathrm{C}_{\text {so }}$ & $\begin{array}{l}\text { saturation } \\
\text { dissolved } \\
\text { oxygen } \\
\text { concentration, } \\
\mathrm{g} / \mathrm{m3}\end{array}$ & SOD & $x_{1}$ & $\begin{array}{l}\text { rate of sediment oxygen } \\
\text { demand, } g / m_{2} \text { sec }\end{array}$ \\
\hline not used & $\mathrm{E}_{\mathrm{c}}$ & $\begin{array}{l}\text { inorganic carbon } \\
\text { interfacial } \\
\text { exchange rate, } \\
\mathrm{m} / \mathrm{sec}\end{array}$ & PO4REL & $x_{2}$ & $\begin{array}{l}\text { anaerobic sediment } \\
\text { release rate, } \mathrm{g} / \mathrm{m}^{2} \mathrm{sec}\end{array}$ \\
\hline not used & $E_{o}$ & $\begin{array}{l}\text { oxygen } \\
\text { interfacial } \\
\text { exchange rate, } \\
\mathrm{m} / \mathrm{sec}\end{array}$ & NH3REL & $x_{3}$ & $\begin{array}{l}\text { sediment ammonia } \\
\text { release rate, } \mathrm{g} / \mathrm{m}^{2} \mathrm{sec}\end{array}$ \\
\hline not used & $F_{1}$ & $\begin{array}{l}\text { total weighted } \\
\text { food for } \\
\text { zooplankton, } \\
\mathrm{g} / \mathrm{m}^{3}\end{array}$ & FEREL & $x_{4}$ & $\begin{array}{l}\text { sediment iron release } \\
\text { rate, } \mathrm{g} / \mathrm{m}^{2} \mathrm{sec}\end{array}$ \\
\hline NH3DK & $\mathrm{K}_{\mathrm{a}}$ & $\begin{array}{l}\text { ammonia- } \\
\text { nitrogen decay } \\
\text { rate, } \sec ^{-1}\end{array}$ & ZS2P & $Z_{1 / 2}$ & $\begin{array}{l}\text { half-saturation coeff. for } \\
\text { zooplankton ingestion, } \\
\mathrm{g} / \mathrm{m}^{3}\end{array}$ \\
\hline COLDK & $\mathrm{K}_{\mathrm{c}}$ & $\begin{array}{l}\text { coliform death } \\
\text { rate, } \sec ^{-1}\end{array}$ & ZEFFIC & $z_{e}$ & $\begin{array}{l}\text { zooplankton ingestion } \\
\text { efficiency }\end{array}$ \\
\hline LABDK & $K_{d}$ & $\begin{array}{l}\text { liable DOM } \\
\text { decay rate, } \sec ^{-1}\end{array}$ & ZOOMIN & $\mathrm{Z}_{\mathrm{L}}$ & $\begin{array}{l}\text { low threshold } \\
\text { concentration for } \\
\text { zooplankton feeding, } \\
\mathrm{g} / \mathrm{m}^{3}\end{array}$ \\
\hline DETDK & $K_{d t}$ & $\begin{array}{l}\text { detritus decay } \\
\text { rate, } \sec ^{-1}\end{array}$ & not used & $\beta$ & $\begin{array}{l}\text { adsorption increment for } \\
\text { Iron }\end{array}$ \\
\hline AEXCR & $\mathrm{K}_{\mathrm{e}}$ & $\begin{array}{l}\text { algal excretion } \\
\text { rate, } \sec ^{-1}\end{array}$ & $\mathrm{H}$ & $\Delta Z$ & cell thickness, $m$ \\
\hline AGROW & $\mathrm{K}_{\mathrm{g}}$ & $\begin{array}{l}\text { algal growth } \\
\text { rate, } \sec ^{-1}\end{array}$ & $\mathrm{BIOC}$ & $\delta_{c}$ & $\begin{array}{l}\text { stoichiometric coeff. for } \\
\text { carbon }\end{array}$ \\
\hline AMORT & $\mathrm{K}_{\mathrm{m}}$ & $\begin{array}{l}\text { algal mortality } \\
\text { rate, } \sec ^{-1}\end{array}$ & BION & $\delta_{N}$ & $\begin{array}{l}\text { stoichiometric coeff. for } \\
\text { nitrogen }\end{array}$ \\
\hline ZMAX & $\mathrm{K}_{\max }$ & $\begin{array}{l}\text { max. ingestion } \\
\text { rate for } \\
\text { zooplankton, } \mathrm{hr}^{-1}\end{array}$ & $\begin{array}{l}\text { O2ALG } \\
\text { O2NH3 } \\
\text { O2DET } \\
\text { O2LAB }\end{array}$ & $\delta_{\mathbf{o i}}$ & $\begin{array}{l}\text { stoichiometric } \\
\text { coefficients for oxygen }\end{array}$ \\
\hline
\end{tabular}




\begin{tabular}{|c|c|c|c|c|c|}
\hline $\begin{array}{l}\text { Control } \\
\text { File }\end{array}$ & $\begin{array}{l}\text { Eq. } \\
\text { Var. }\end{array}$ & Definition & $\begin{array}{l}\text { Control } \\
\text { File }\end{array}$ & $\begin{array}{l}\text { Eq. } \\
\text { Var. }\end{array}$ & Definition \\
\hline NO3DK & $K_{n}$ & $\begin{array}{l}\text { nitrate-nitrogen } \\
\text { decay rate, } \mathrm{sec}^{-1}\end{array}$ & O2RESP & $\delta_{o z}$ & $\begin{array}{l}\text { stoichiometric coeff. } \\
\text { between biological } \\
\text { constituents and } \mathrm{O}_{2} \text { for } \\
\text { respiration }\end{array}$ \\
\hline REFDK & $K_{T}$ & $\begin{array}{l}\text { refractory DOM } \\
\text { decay rate, } \mathrm{sec}^{-1}\end{array}$ & BIOP & $\delta_{\mathbf{P}}$ & $\begin{array}{l}\text { stoichiometric coeff. for } \\
\text { phosphorus }\end{array}$ \\
\hline ARESP & $K_{r s}$ & $\begin{array}{l}\text { algal dark } \\
\text { respiration rate, } \\
\sec ^{-1}\end{array}$ & iiiDT1 & $\gamma_{18}$ & $\begin{array}{l}\text { temperature rate } \\
\text { multiplier for ascending } \\
\text { portion of the curve }\end{array}$ \\
\hline SEDDK & $K_{s}$ & $\begin{array}{l}\text { sediment decay } \\
\text { rate, } \sec ^{-1}\end{array}$ & iiiDT3 & $\gamma_{28}$ & $\begin{array}{l}\text { temperature rate } \\
\text { multiplier for descending } \\
\text { portion of the curve }\end{array}$ \\
\hline LRFDK & $K_{1}$ & $\begin{array}{l}\text { transfer rate } \\
\text { from liable to } \\
\text { refractory DOM, } \\
\sec ^{-1}\end{array}$ & $\begin{array}{l}\text { iiiDT2 } \\
\text { iiiDT4 }\end{array}$ & $\gamma_{\text {ii }}$ & $\begin{array}{l}\text { temperature rate } \\
\text { multipliers }\end{array}$ \\
\hline not used & $K_{z i}$ & $\begin{array}{l}\text { zooplankton } \\
\text { ingestion rate, } \\
\mathrm{hr}^{-1}\end{array}$ & not used & $\theta$ & temperature factor \\
\hline ZMORT & $K_{\mathrm{zm}}$ & $\begin{array}{l}\text { zooplankton } \\
\text { mortality rate, hr }\end{array}$ & FESETL & $\omega_{4}$ & $\begin{array}{l}\text { Iron settling velocity, } \\
\mathrm{m} / \mathrm{sec}\end{array}$ \\
\hline ZRESP & $\mathrm{K}_{\mathrm{zr}}$ & $\begin{array}{l}\text { zooplankton } \\
\text { respiration rate, } \\
\mathrm{hr}^{-1}\end{array}$ & DSETL & $\omega_{2}$ & $\begin{array}{l}\text { detritus settling velocity, } \\
\mathrm{m} / \mathrm{sec}\end{array}$ \\
\hline DETDK & $K_{b}$ & $\begin{array}{l}\text { CBOD decay } \\
\text { rate, } \sec ^{-1}\end{array}$ & ASETL & $\omega_{3}$ & $\begin{array}{l}\text { algal settling velocity, } \\
\mathrm{m} / \mathrm{sec}\end{array}$ \\
\hline
\end{tabular}




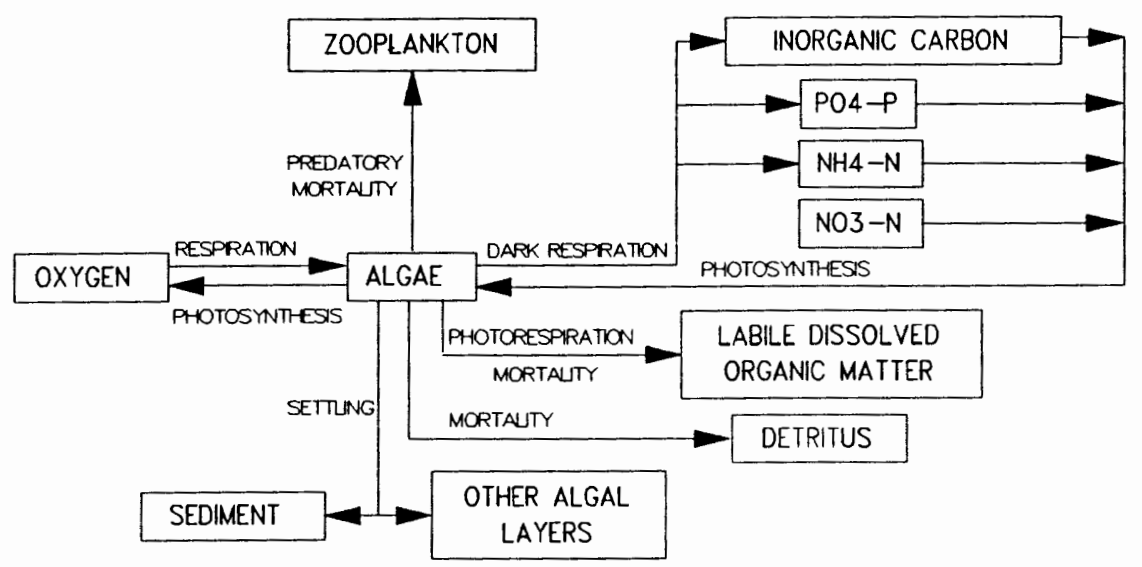

Figure A.1. Algae Sources and Sinks.

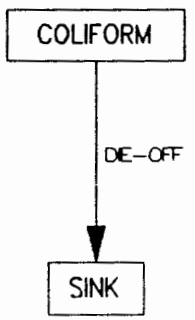

Figure A.2. Coliform first-order decay process. 


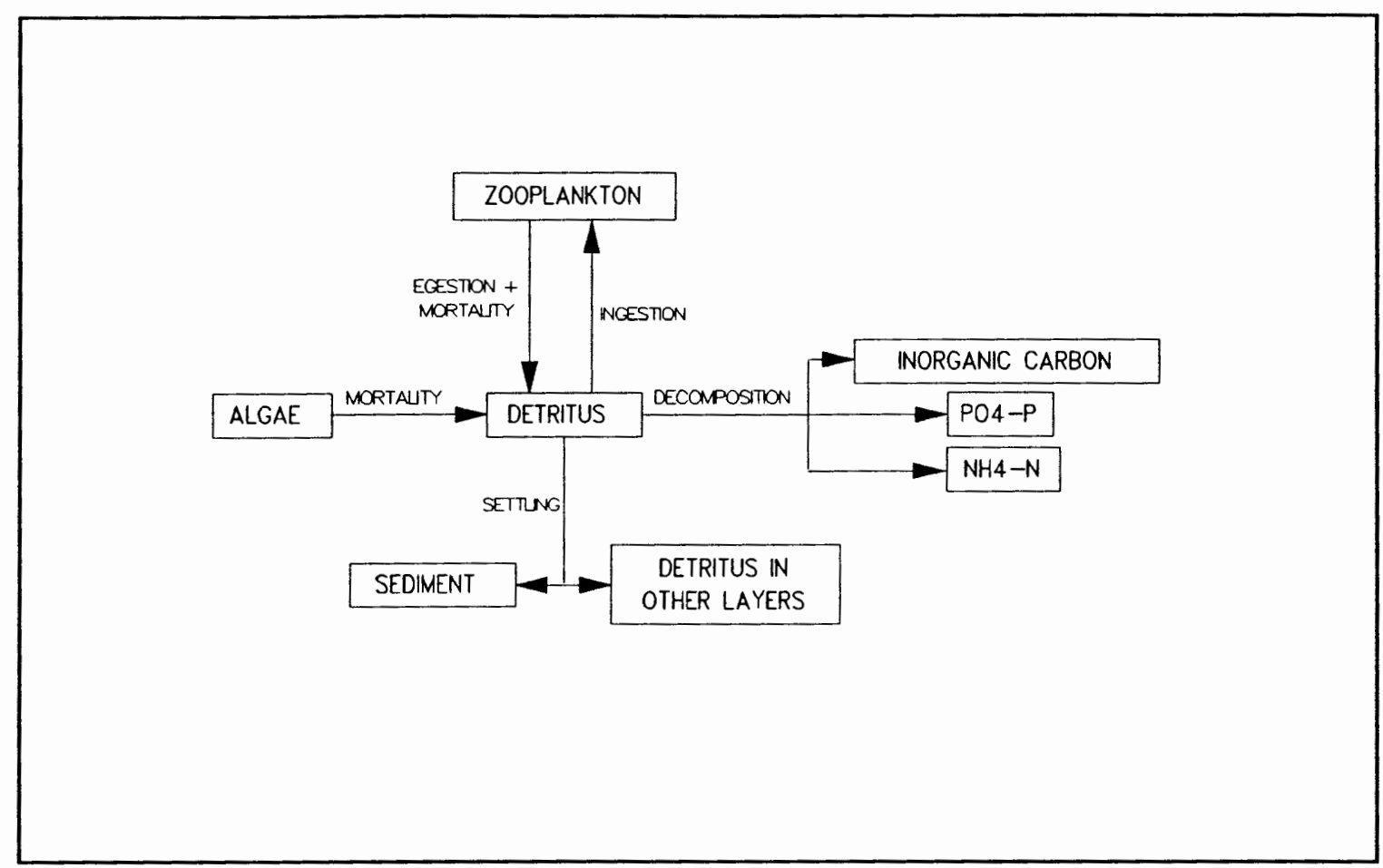

Figure A.3. Detritus sources and sinks.

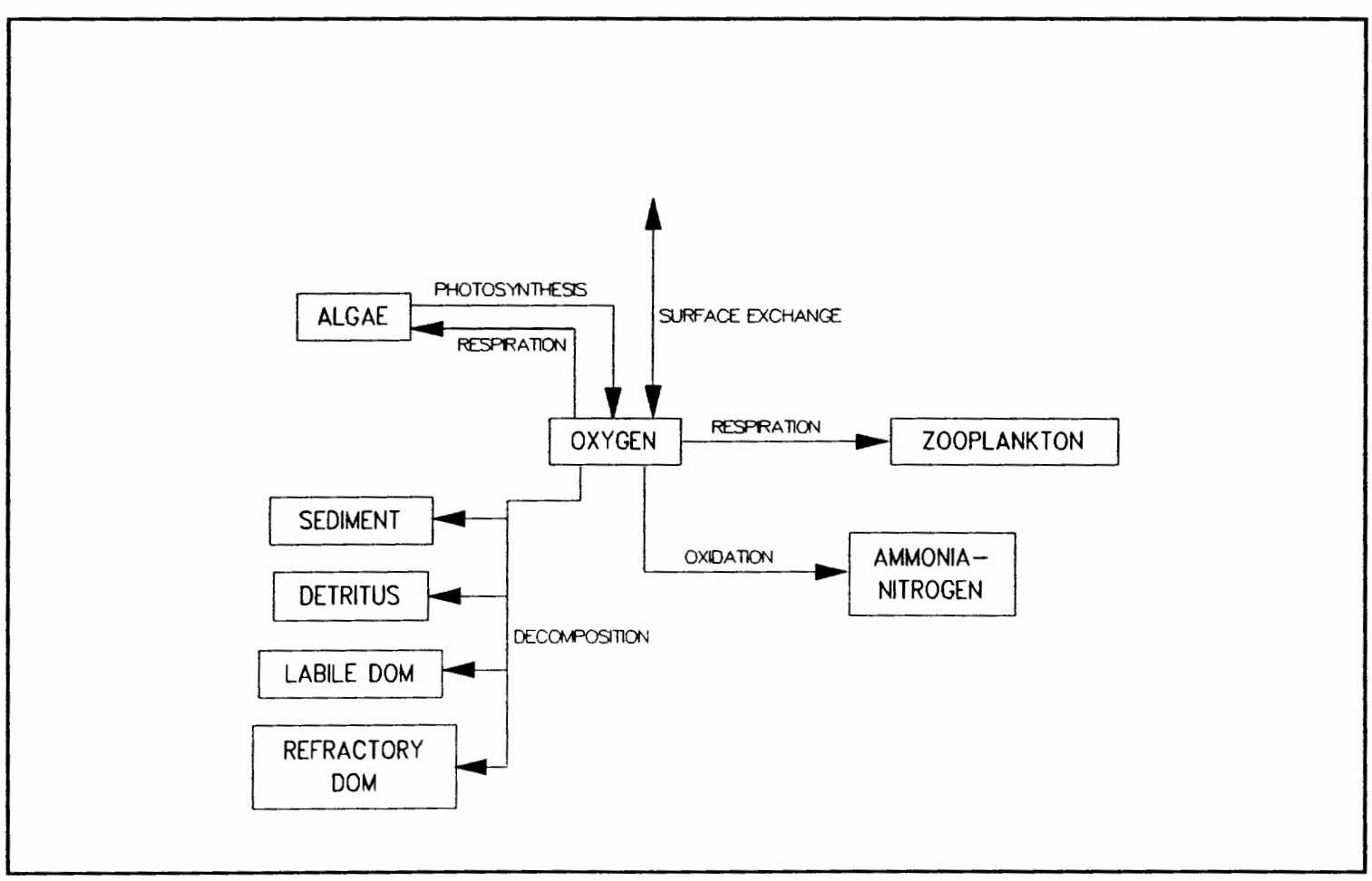

Figure A.4. Dissolved Oxygen sources and sinks. 


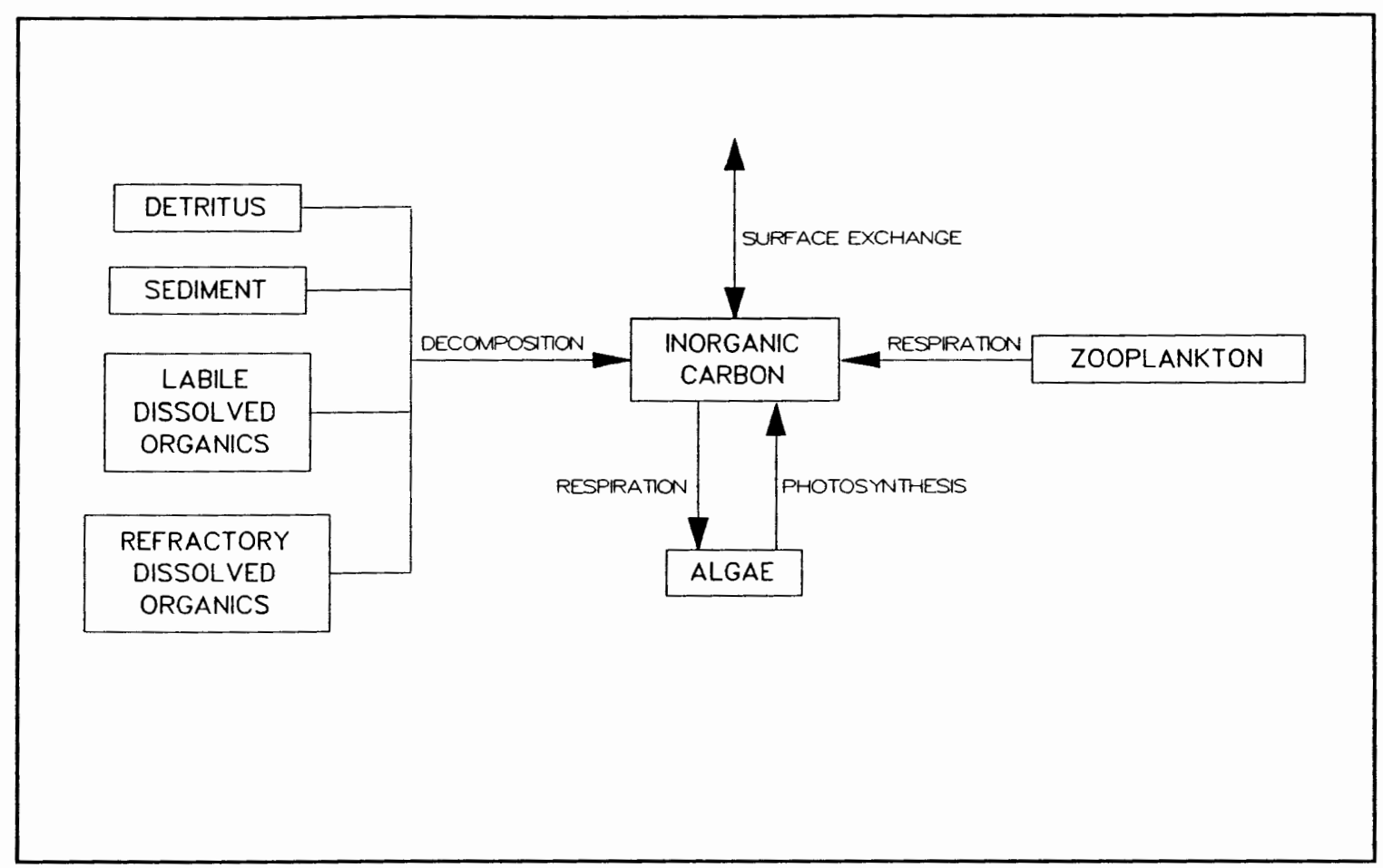

Figure A.5. Inorganic Carbon sources and sinks.

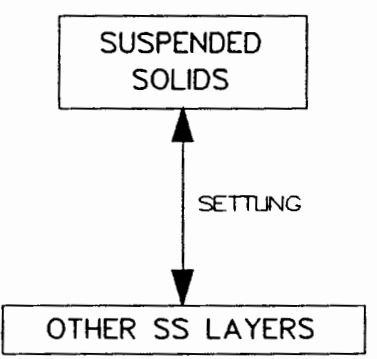

Figure A.6. Inorganic suspended solids sedimentation. 


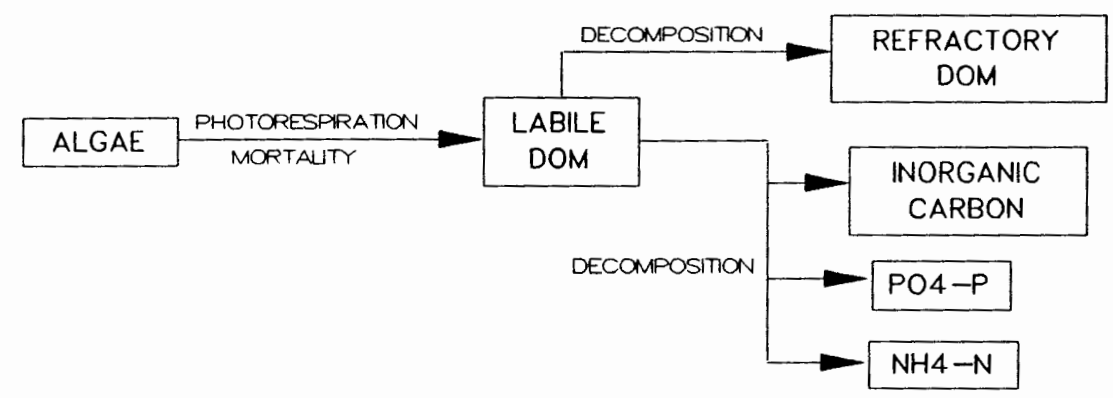

Figure A.7. Labile dissolved organic matter sources and sinks.

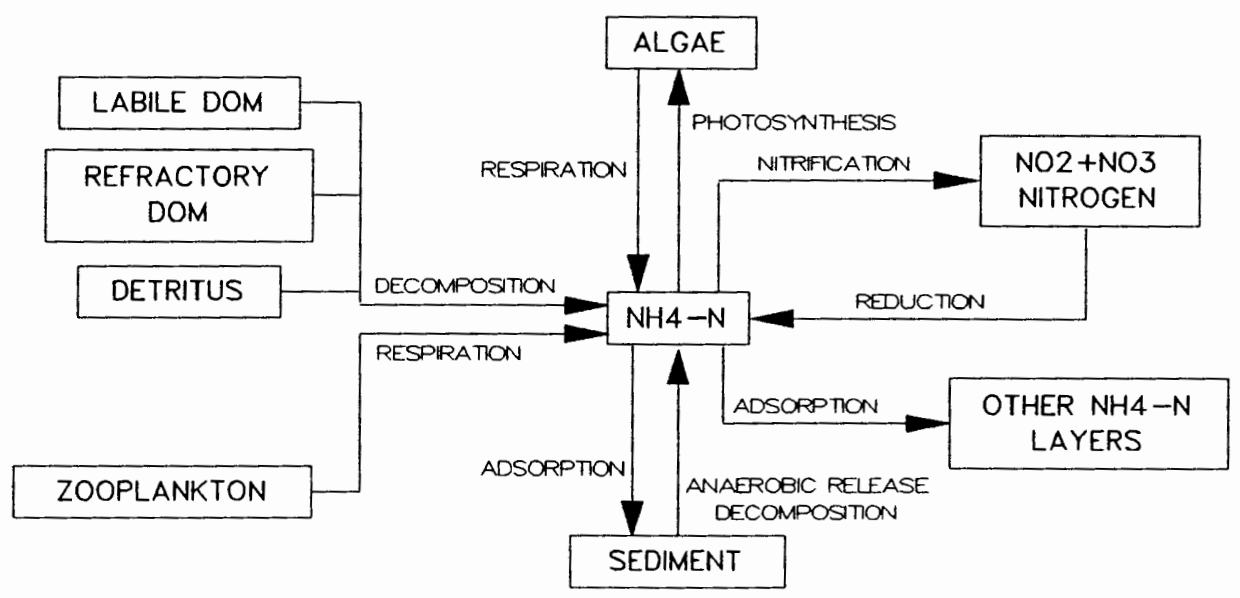

Figure A.8. Ammonia-N sources and sinks. 


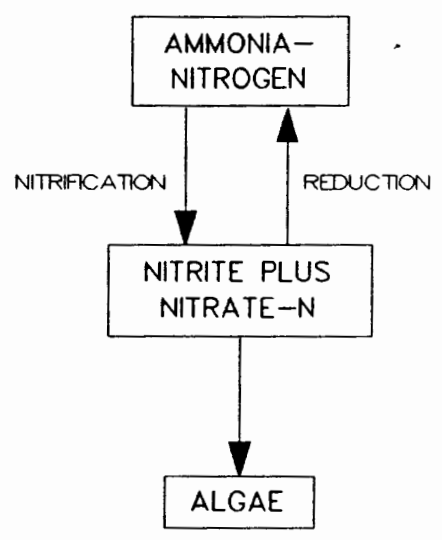

Figure A.9. Nitrite \& Nitrate sources and sinks.

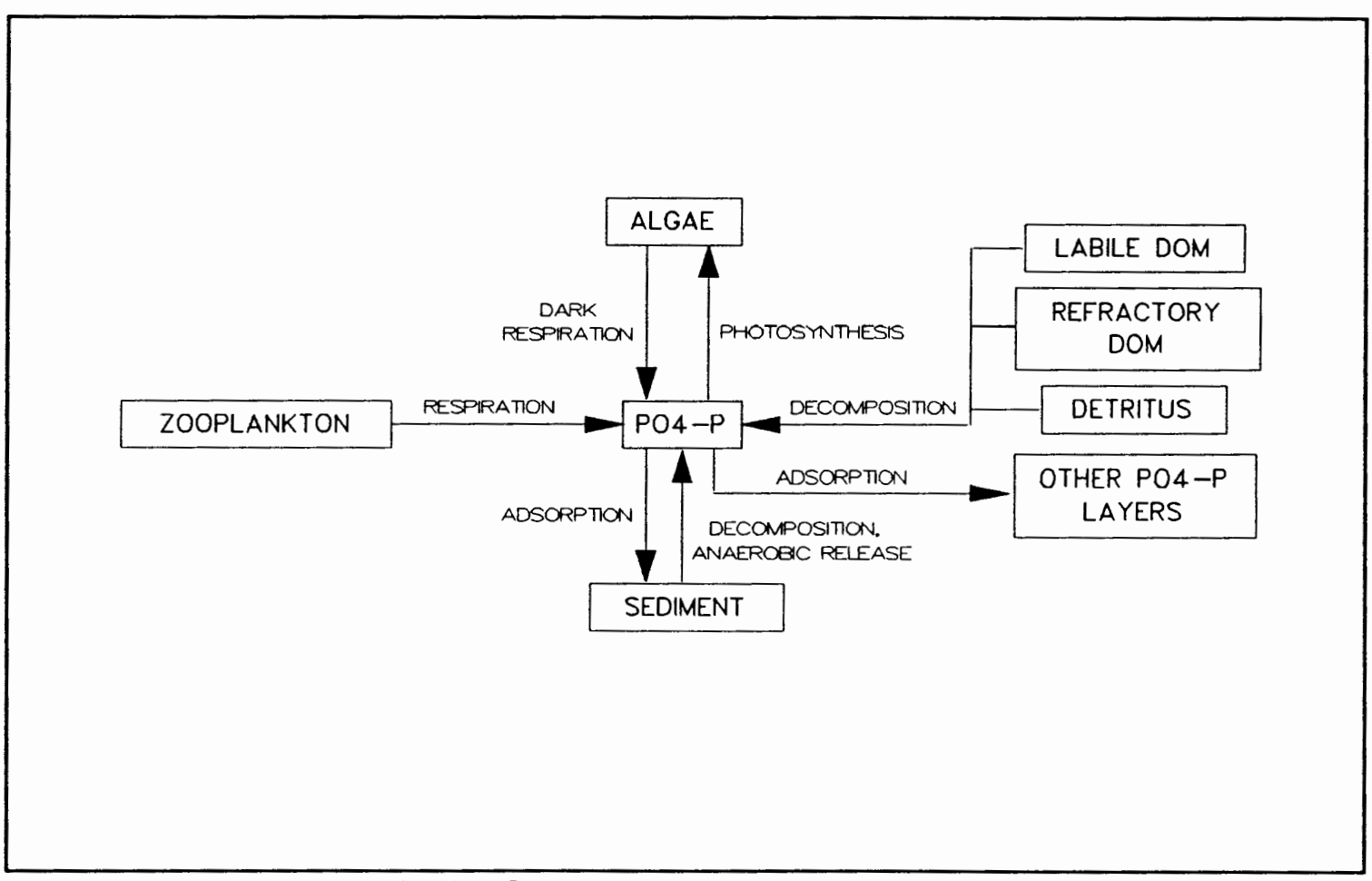

Figure A.10. Ortho-phosphorus sources and sinks. 


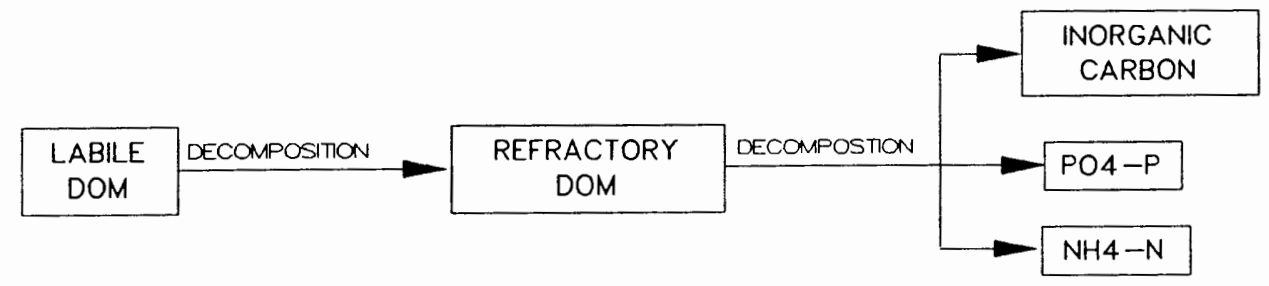

Figure A.11. Refractory dissolved organic matter sources and sinks.

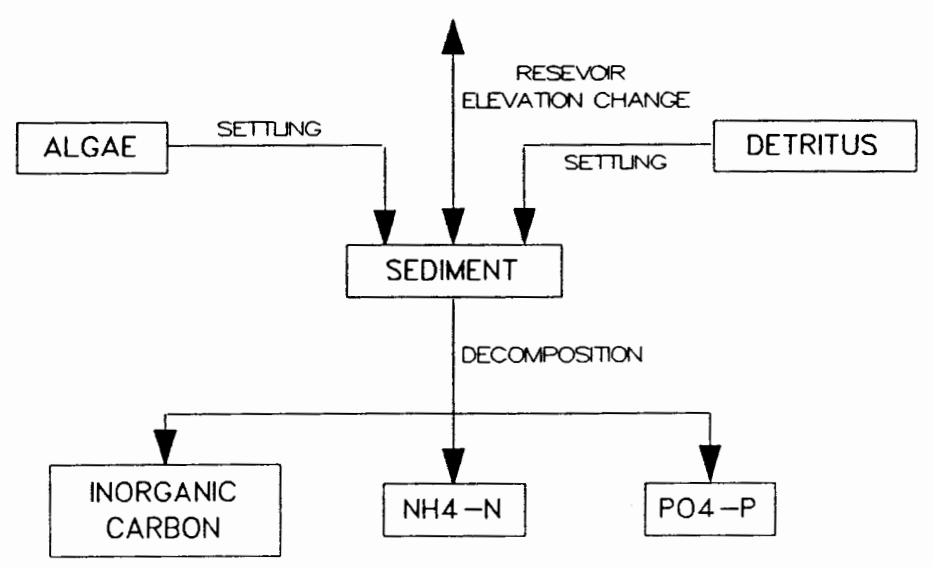

Figure A.12. Sediment accumulation/deposition. 


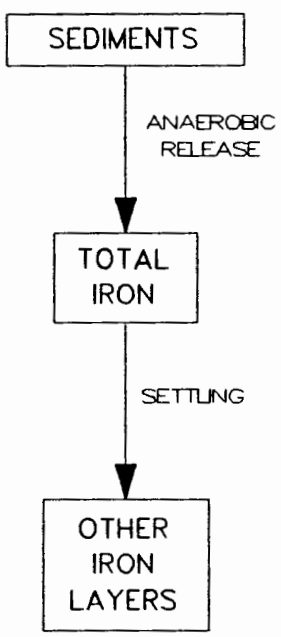

Figure A.13. Total iron sources and sinks.

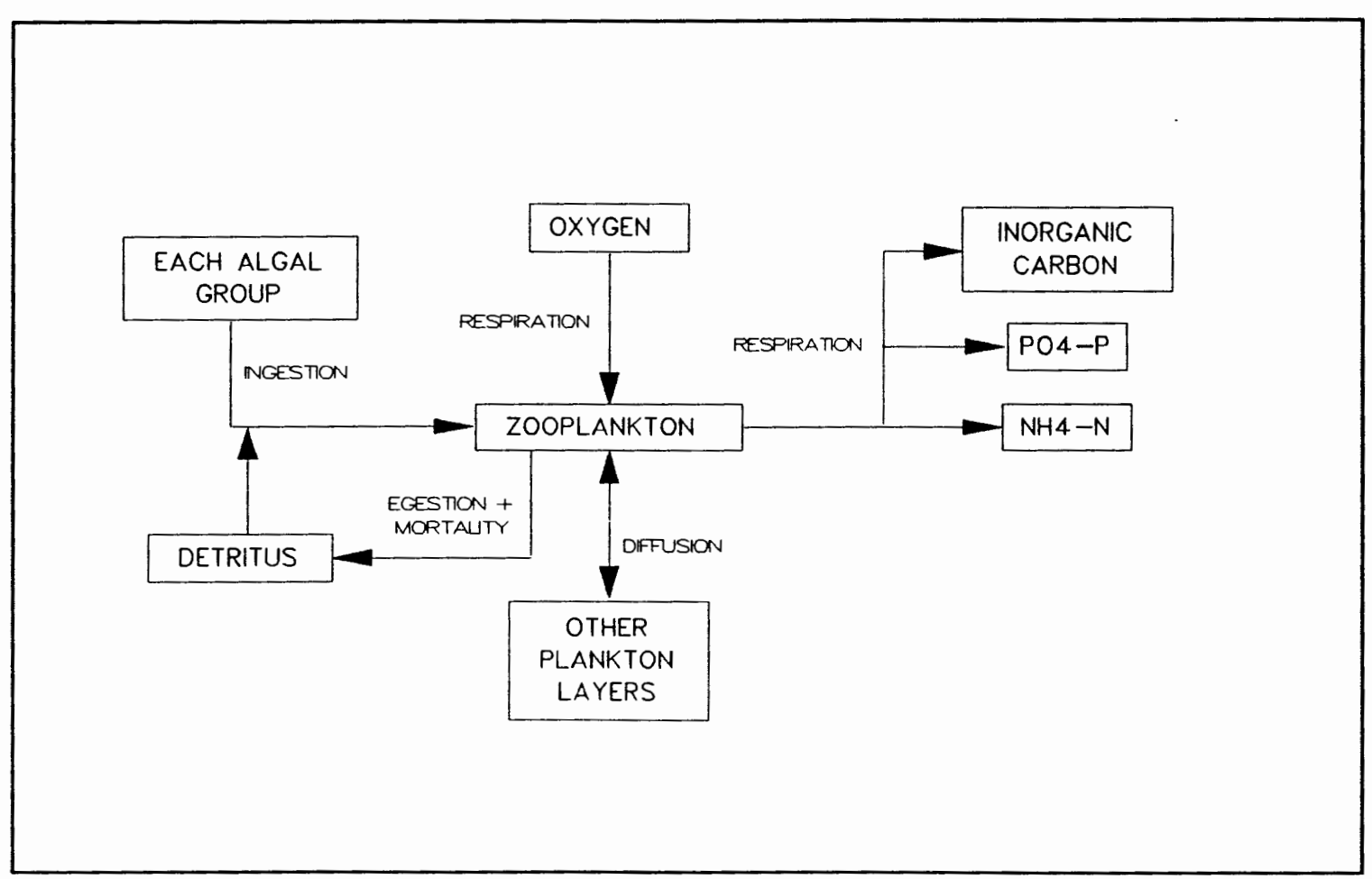

Figure A.14. Zooplankton sources and sinks. 
APPENDIX B

USER'S MANUAL FOR MODIFIED VERSION OF

CE-QUAL-W2 MODEL OF THE LOWER

TUALATIN RIVER 
APPENDIX B

USER'S MANUAL FOR MODIFIED VERSION OF

CE-QUAL-W2 MODEL OF THE LOWER

TUALATIN RIVER

This appendix summarizes the set-up and execution of the CE-QUAL-W2 for Tualatin River pool from RM 3.5 to RM 32 . Companion reports that are important for running the model include the original User's Manual for CE-QUAL-W2, Corps of Engineers (1986), and the revised draft form of the CE-QUALW2 User's Manual, Corps of Engineers (1990). The revised 1990 Corps manual is included on the enclosed diskette.

Whenever a difference between a corps of Engineer's manual and this report are noted, this report supersedes the two Corps of Engineers' manuals.

\section{FILE ORGANIZATION}

The model files fall into several categories as shown in Table $\mathrm{B}-1$. Descriptions of these files are included in the text below. Files for water withdrawals are not shown in Table B-1 but will have the same format as branch inflow files.

Note that for each input data file described below, the first three lines of the file are reserved for user titles. 
Meteorological Data

Meteorological data required for the model included air temperature, dew-point temperature, wind speed and direction, and percent of cloudiness as a function of Julian day. The file met91.npt has daily average values of these meteorological parameters as a function of Julian day for 1990. The file is arranged in the following format: Julian day, air temperature $\left({ }^{\circ} \mathrm{C}\right)$, dew-point temperature $\left({ }^{\circ} \mathrm{C}\right)$, wind speed $(\mathrm{m} / \mathrm{s})$, wind direction (radians from $\mathrm{N}$ ), percent of cloudiness (in tenths) in $7 \mathrm{~F} 8.2$ format.

TABLE B-1

ORGANIZATION OF THE TUALATIN RIVER MODEL COMPUTER FILES

\begin{tabular}{||l|l|l|}
\hline Type of file & $\begin{array}{l}\text { File name for } \\
\text { Tualatin River } \\
\text { pool section }\end{array}$ & File description \\
\hline \hline $\begin{array}{l}\text { Main control } \\
\text { file }\end{array}$ & t2a_con.npt & $\begin{array}{l}\text { control file with run } \\
\text { information, } \\
\text { output/input files } \\
\text { descriptors, model } \\
\text { coefficients, etc., } \\
\text { see 1990 corps draft } \\
\text { manual }\end{array}$ \\
\hline $\begin{array}{l}\text { Bathymetry } \\
\text { file }\end{array}$ & t2abth.npt & $\begin{array}{l}\text { cell widths in m as a } \\
\text { function of vertical } \\
\text { and longitudinal cell, } \\
\text { cell bottom friction } \\
\text { factor, and } \\
\text { longitudinal cell } \\
\text { length }\end{array}$ \\
\hline
\end{tabular}




\begin{tabular}{|c|c|c|}
\hline Type of file & $\begin{array}{l}\text { File name for } \\
\text { Tualatin River } \\
\text { pool section }\end{array}$ & File description \\
\hline $\begin{array}{l}\text { Branch inflow } \\
\text { file }\end{array}$ & qin_t2a.npt & $\begin{array}{l}\text { flow rates }\left(\mathrm{m}^{3} / \mathrm{s}\right) \text { as a } \\
\text { function of Julian day } \\
\text { for the upstream } \\
\text { inflow to the model } \\
\text { segment }\end{array}$ \\
\hline $\begin{array}{l}\text { Branch inflow } \\
\text { file }\end{array}$ & tin_t2a.npt & $\begin{array}{l}\text { temperature }\left({ }^{\circ} \mathrm{C}\right) \text { as a } \\
\text { function of Julian day } \\
\text { for the upstream } \\
\text { inflow to the model } \\
\text { segment }\end{array}$ \\
\hline $\begin{array}{l}\text { Branch inflow } \\
\text { file }\end{array}$ & cin_t2a.npt & $\begin{array}{l}\text { water quality } \\
\text { constituent as a } \\
\text { function of Julian day } \\
\text { for the upstream } \\
\text { inflow to the model } \\
\text { segment; the order of } \\
\text { water quality } \\
\text { parameters is noted in } \\
\text { the main control file }\end{array}$ \\
\hline \multirow[t]{3}{*}{$\begin{array}{l}\text { Tributary } \\
\text { input files }\end{array}$} & qtr*.npt & $\begin{array}{l}\text { flow rates }\left(\mathrm{m}^{3} / \mathrm{s}\right) \text { as a } \\
\text { function of Julian day } \\
\text { for each tributary } \\
\text { coming into the } \\
\text { system, the tributary } \\
\text { input location on the } \\
\text { main branch is shown } \\
\text { in the main control } \\
\text { file }\end{array}$ \\
\hline & ttr*.npt & $\begin{array}{l}\text { temperature }\left({ }^{\circ} \mathrm{C}\right) \text { as a } \\
\text { function of Julian day } \\
\text { for each tributary } \\
\text { coming into the system }\end{array}$ \\
\hline & $\operatorname{ctr*} \cdot \mathrm{npt}$ & $\begin{array}{l}\text { water quality } \\
\text { constituent as a } \\
\text { function of Julian day } \\
\text { for each tributary } \\
\text { coming into the system }\end{array}$ \\
\hline
\end{tabular}




\begin{tabular}{|l|l|l|}
\hline Type of file & $\begin{array}{l}\text { File name for } \\
\text { Tualatin River } \\
\text { pool section }\end{array}$ & File description \\
\hline \hline Outflow file & $\begin{array}{l}\text { flow over the } \\
\text { diversion dam } \\
\text { is computed } \\
\text { internally in } \\
\text { the model }\end{array}$ & $\begin{array}{l}\text { outflow vertical } \\
\text { location and flow rate }\end{array}$ \\
\hline $\begin{array}{l}\text { Meteorological } \\
\text { data file }\end{array}$ & met91.npt & $\begin{array}{l}\text { meteorological data } \\
\text { file providing daily } \\
\text { averaged values of air } \\
\text { temperature, dew-point } \\
\text { temperature, wind } \\
\text { speed and direction, } \\
\text { and percent cloudiness }\end{array}$ \\
\hline $\begin{array}{l}\text { Executable } \\
\text { code for } \\
386 / 486 \text { PC }\end{array}$ & w2pool.exe & $\begin{array}{l}\text { compiled executable } \\
\text { for the model, to run } \\
\text { make sure one has 4 MB } \\
\text { of RAM and set } \\
\text { files=45 in config.sys }\end{array}$ \\
\hline $\begin{array}{l}\text { FORTRAN source } \\
\text { code }\end{array}$ & w2pool.for & $\begin{array}{l}\text { FoRTRAN PSU CE-QUAL-W2 } \\
\text { model source code }\end{array}$ \\
\hline INCLUDE file & w2.inc & $\begin{array}{l}\text { Include file used } \\
\text { during compilation of } \\
\text { the FoRTRA source } \\
\text { code }\end{array}$ \\
\hline Output files & *.opt & $\begin{array}{l}\text { the output files are } \\
\text { specified in the main } \\
\text { control file and can } \\
\text { be turned on/off } \\
\text { depending on data } \\
\text { needs }\end{array}$ \\
\hline
\end{tabular}

\section{Flow and Pollutant Loading Data}

A summary of the dynamic flow and pollutant loading (temperature and water quality concentrations) files are shown in Table B-1. All inflows are specified an input cell location (see main control file under 'TRIB SEG'). The 
vertical placement of the inflow is determined by the inflow density and the vertical density profile of the slough at the input location. The file formats for each file are: (i) the flow or $q$ files: Julian day, flow in $\mathrm{m}^{3} / \mathrm{s}$ in $2 \mathrm{F8.3}$; (ii) the temperature or $t$ files: Julian day, temperature in ${ }^{\circ} \mathrm{C}$ in 2F8.3; and (iii) the constituent concentration or $\mathrm{C}$ files: Julian day, concentration of active constituent in $\mathrm{mg} / \mathrm{I}$ (defined in the main control file under 'CTR CON') in 19F7.3. (Note that for carbon and alkalinity, the concentrations are specified as $\mathrm{mg} / \mathrm{l}$ as $\mathrm{CaCO}_{3}$ )

\section{Geometry of the system}

The geometry of the system is defined by specifying the cell width in $m$ (defined at the top of the vertical cell) for each longitudinal (i) and vertical (k) cell location. Inactive cells of $0 \mathrm{~m}$ width are also specified at the top and bottom of the computational grid.

The bathymetry file t2abth.npt contains geometry data for the Tualatin River pool area. The format of the file for each longitudinal cell was (//(10F8.3)).

Some of the longitudinal cells did not have constant longitudinal cell spacing. This variation of cell spacing was included at the beginning of the bathymetry file. The $\Delta x$ for each longitudinal cell was in the following format: $(/ /(10 F 8.3))$ 
Spatial Variation of cell Bottom Friction

The variation of Manning's friction factor from cell to cell was used as a calibration tool for the model. The Manning's coefficient was specified for each longitudinal cell of the model near the beginning of t2abth.npt. The format for the file is $9 \mathrm{~F} 8.3$ for each line of sequential friction factors. The sequence of friction factors corresponds to the sequence of longitudinal cells.

\section{Input Data File organization}

In addition to compiling all the boundary condition data, geometry, and cell bottom friction information for the system, the input data files for the runs also include the w2.inc file and the main control file t2a_con.npt. The w2.inc file is a parameter and common block file inserted into the FORTRAN source code during compilation. The t2a_con.npt file is the main control file organizing the model simulation (specifying input/output files, model parameters, system geometry, etc.). See the 1990 corps of Engineers manual for a description of this file.

\section{RUNNING THE MODEL}

The model can be run after all the input data files are successfully created and the source code is successfully compiled and linked using a FORTRAN-77 compiler. Output 
files are then evaluated by the user. Output files (*.opt) are specified by the user in the main control file.

Suggestions for running the code include using either a $386 / 33$ (with math co-processor) or $486 / 25-33$ PC with 4-8 MB extended memory and an extended memory FORTRAN compiler (eg., Salford FTN77, Lahey, Silicon Valley Software, NDP Microway, WATCOM, etc.) at the minimum. A Weitek coprocessor will enhance the computational speed on a PC by up to $100 \%$. The code may more easily run on a UNIX workstation with a FORTRAN-77 compiler than on a PC with DOS. The UNIX environment does not have the potential problems that may arise in the DOs environment because of extended memory management (that depends on how well your DOS extender, which is part of the extended memory FORTRAN compiler, handles memory above $640 \mathrm{~K})$.

\section{FILE DIRECTORY}

The files for running the model are included on one 1.44MB 3.5" floppy disk. The disk has the self-extracting compressed files manual.exe and tpool.exe.

To extract the files from these "zipped" executables on the disk for a Dos system, merely type the name of the executable. The files will then be decompressed. Directories of the files in each compressed file are shown below in Tables B-2 and B-3. 
For running each simulation, all the files in the compressed file should be in a directory on the computer hard disk because similar names of files may be used for different simulations.

TABLE B-2

USER'S MANUAL

\begin{tabular}{|c|c|c|}
\hline File name & $\begin{array}{c}\text { Zip file } \\
\text { (compressed } \\
\text { file) }\end{array}$ & \multicolumn{1}{|c|}{ Comments } \\
\hline w2man.wp5 & manual.exe & $\begin{array}{l}\text { 1990 Corps of Engineers draft } \\
\text { manual for the CE-QUAL-W2 } \\
\text { model in Wordperfect 5.1 } \\
\text { format }\end{array}$ \\
\hline
\end{tabular}

TABLE B-3

SIMULATION FILES FOR THE

TUALATIN RIVER POOL

\begin{tabular}{|c|c|c|}
\hline File name & $\begin{array}{l}\text { Zip file } \\
\text { (compressed } \\
\text { file) }\end{array}$ & Comments \\
\hline w2pool.for & tpool.exe & $\begin{array}{l}\text { FORTRAN source code for } \\
\text { Tualatin pool including flow } \\
\text { over the dam algorithm }\end{array}$ \\
\hline w2 . inc & tpool.exe & include file \\
\hline t2a_con.npt & tpool.exe & $\begin{array}{l}\text { input file for Tualatin River } \\
\text { pool including the outflow } \\
\text { from Durham treatment plant }\end{array}$ \\
\hline met91.npt & tpool.exe & 1991 meteorological data \\
\hline t2abth.npt & tpool.exe & bathymetry file \\
\hline w2pool.exe & tpool.exe & $\begin{array}{l}\text { LAHEY executable for } 386 / 486 \\
\text { PC }\end{array}$ \\
\hline
\end{tabular}




\begin{tabular}{|c|c|c|}
\hline File name & $\begin{array}{c}\text { Zip file } \\
\text { (compressed } \\
\text { file) }\end{array}$ & Comments \\
\hline qtr_dur.npt & tpool.exe & $\begin{array}{l}1991 \text { flow of effluent from } \\
\text { Durham wastewater treatment } \\
\text { plant }\end{array}$ \\
\hline ctr_dur.npt & tpool.exe & $\begin{array}{l}1991 \text { concentration of } \\
\text { constituents from Durham } \\
\text { wastewater treatment facility }\end{array}$ \\
\hline ttr_dur.npt & tpool.exe & $\begin{array}{l}1991 \text { temperature of effluent } \\
\text { from Durham wastewater } \\
\text { treatment plant }\end{array}$ \\
\hline qtr_fan.npt & tpool.exe & 1991 flow of Fanno Creek \\
\hline ctr_fan.npt & tpool.exe & $\begin{array}{l}1991 \text { concentration of } \\
\text { constituents from Fanno Creek }\end{array}$ \\
\hline ttr_fan.npt & tpool.exe & $\begin{array}{l}1991 \text { temperature of Fanno } \\
\text { Creek }\end{array}$ \\
\hline qin_t2a.npt & tpool.exe & $\begin{array}{l}\text { flow from Upper Tualatin } \\
\text { River }\end{array}$ \\
\hline cin_t2a.npt & tpool.exe & $\begin{array}{l}\text { concentration from Upper } \\
\text { Tualatin River }\end{array}$ \\
\hline tin_t2a.npt & tpool.exe & $\begin{array}{l}\text { temperature inputs from Upper } \\
\text { Tualatin River }\end{array}$ \\
\hline dam. in & tpool.exe & $\begin{array}{l}\text { characteristics of diversion } \\
\text { dam at RM } 3.5\end{array}$ \\
\hline qot_t2a.npt & tpool.exe & $\begin{array}{l}\text { file is required to be in } \\
\text { directory in which model is } \\
\text { run, but it has no effect on } \\
\text { outflows from the diversion } \\
\text { dam since this is calculated } \\
\text { internally }\end{array}$ \\
\hline vpr_t2a.npt & tpool.exe & $\begin{array}{l}\text { initial vertical temperature } \\
\text { of the Tualatin pool; in the } \\
\text { main control file } \\
\text { t2a con.npt, this file is } \\
\text { presently not used } \\
\text { (temperature is set initially } \\
\text { to an isothermal value) }\end{array}$ \\
\hline
\end{tabular}




\begin{tabular}{|l|c|c|}
\hline File name & $\begin{array}{c}\text { Zip file } \\
\text { (compressed } \\
\text { file) }\end{array}$ & Comments \\
\hline \hline f7713.eer & tpool.exe & FORTRAN error message file \\
\hline
\end{tabular}

The executable files provided were compiled with Lahey FORTRAN F77L-32 Version 5.0 with optimizations. They will run on a $386 / 486$ PC with extended memory (4 MB RAM). To execute the program, merely type the name of the executable at the Dos prompt and hit the return key. Depending on the run length in days and the speed of the PC, the program can run for many hours. For the Tualatin pool code, the average CPU time on a $486 / 50$ PC was about 3 minutes/simulation day. The f7713.eer file creates an error message in case there is an error in the input files or some other yet-tobe-encountered unknown condition.

RUNNING THE MODEL ON A $386 / 486$ PC

One disk has been provided that contains all the files necessary to run the model on a $386 / 486$ PC with a minimum of 4 MB of RAM, DOS 3.3 or higher, and a numeric co-processor. Before running the model, make sure the files parameter in the config.sys file is set to 45 , i.e., files $=45$. As suggested already, a directory could be established: TPOOL by using the command mkdir <ret>, etc.. The self-extracting exe file from the disk would be copied to the directory, 
copy tpool.exe to TPOOL directory, e.g., if disk is in b: drive, copy b:tpool.exe c:|tpool <ret>, etc. Since the FORTRAN source code is not necessary for executing the program, one can delete any *.for files to conserve disk space.

Running the model consists of typing the executable name once one is in the directory. For example, in the TPOOL directory, type tpool <ret>. The program will produce a header showing Lahey FORTRAN and Phar-Lap DOS extender and the amount of available extended memory. once the program has finished executing, the Dos prompt will re-appear. At that point, one can examine the *.opt (output) files produced by the model. Changes in input files (*.npt) can be made to examine model coefficient sensitivities, etc. 